\title{
Partisan Entrepreneurship
}

\author{
Joseph Engelberg Jorge Guzman Runjing Lu William Mullins* \\ UC San Diego \\ Columbia \& NBER \\ U. of Alberta \\ UC San Diego
}

October 5, 2022

\begin{abstract}
Republicans start more firms than Democrats. In a sample of 40 million party-identified Americans between 2005 and 2017, we find that 6\% of Republicans and $4 \%$ of Democrats become entrepreneurs. This partisan entrepreneurship gap is time-varying: Republicans increase their relative entrepreneurship during Republican administrations and decrease it during Democratic administrations, amounting to a partisan reallocation of 170,000 new firms over our 13-year sample. We find sharp changes in partisan entrepreneurship around the elections of President Obama and President Trump, and the strongest effects among the most politically active partisans: those that donate and vote.
\end{abstract}

Keywords: Entrepreneurship, Politics, Partisanship

JEL Classification Numbers: L26, G41, G51, M13

\footnotetext{
*Engelberg, jengelberg@ucsd.edu; Guzman, jorge.guzman@columbia.edu; Lu, runjing1@ualberta.ca; Mullins, wmullins@ucsd.edu. We thank Jean-Noel Barrot, Asaf Bernstein, Tony Cookson, Mike Ewens, Janet Gao, Nataliya Gerasimova, Marco Giacoletti, Yael Hochberg, Sabrina Howell, Glenn Hubbard, Adrien Matray, W. Ben McCartney, David Robinson, Antoinette Schoar, Scott Stern, Rick Townsend, Jonathan Zandberg and seminar participants at NBER Entrepreneurship SI, Rice, HEC Paris, Colorado Finance Summit, Midwest Finance, LAFA, LMU, Columbia, SoCal Private Equity, and the University of Virginia for valuable comments. (C)2022.
} 


\section{INTRODUCTION}

In the United States, political identity is central to economic expectations: Americans are much more optimistic about the economy when their political party is in power. Republicans were markedly more optimistic than Democrats during the administrations of George W. Bush and Donald Trump - by almost two standard deviations (Figure 1) - but this difference disappeared during the Democratic administrations of Bill Clinton and Barack Obama.

This paper examines whether changes in political regime and the corresponding shifts in partisan beliefs translate into a critical economic behavior: entrepreneurship. To do this, we consider a sample of approximately 40 million Americans for whom we have political party identification and who live in the 33 states for which we have complete data on firm founders from the Startup Cartography Project (Andrews et al., 2020). ${ }^{1}$ We find that Republicans are more likely to be entrepreneurs than Democrats: over our 13-year sample, 5.5\% of Republicans started a business, compared to 3.7\% of Democrats. Even after controlling for age, gender, race, education, income and county-year fixed effects, Republicans are $26 \%$ more likely than Democrats to start a business in a given year, relative to the mean.

To examine the effects of political regime changes on entrepreneurship among Republicans and Democrats, we perform individual-level difference-in-differences (DID) event studies around two presidential elections. These compare individual Republicans and Democrats in the same county before vs. after the party-changing presidential elections of 2008 and 2016. We find that Republicans decrease their likelihood of starting a business in the year following Obama's election by $3.4 \%$ of the mean relative to Democrats and increase their relative entrepreneurship after Trump's election by $2.4 \%$.

Our DID event studies focus on the years immediately surrounding party-changing elections and thus use less than half of the sample years. When we consider the entire sample

\footnotetext{
${ }^{1}$ These 33 states cover $69 \%$ of U.S. GDP as of 2016.
} 
(2005 - 2017), we find that politically mismatched individuals - that is, voters whose party did not control the presidency - have a probability of starting a business that is $3.3 \%$ of the mean lower than those whose party is in power. Our effect size corresponds to an annual difference of 13,000 new firms between politically matched versus mismatched individuals.

Moreover, the largest estimated effects occur among the most politically active individuals. We estimate an effect size for partisans with a below-median voting propensity of $2.4 \%$ of the mean, but for those with an above-median voting propensity the effect expands to $4.3 \%$. Using FEC-reported donations to a political party as an alternative measure of political engagement, the effect among politically active individuals jumps to $10 \%$.

We also examine the types of firms founded in our sample, because firm characteristics at founding have been shown to capture growth potential and thus economic impact (Schoar, 2010, Guzman and Stern, 2020, Sterk et al., 2021). We find that corporations are much more responsive than LLCs (an effect size of $10.7 \%$ versus $0.7 \%$ of the mean). ${ }^{2}$ Our main result is also present across the full range of the firm quality distribution of Guzman and Stern (2020), and high quality startups appear to be especially sensitive to political regime change. Our mismatch estimate for firms in the top $5 \%$ of the quality distribution, which captures over half of high growth firms, is nearly seven times as large as that of LLCs $(4.8 \%$ versus $0.7 \%$ of the mean).

Next, we turn to founder characteristics, where we find strong partisan differences by gender, age, and income. First, we find the well-known gender gap in our data: $6.6 \%$ of men and $3.2 \%$ of women started a business in our 13-year sample. After controlling for individual characteristics and county-year fixed effects, men are about 0.4 percentage points (pp) per year more likely to start a business than women, a difference of approximately 90\% of the annual mean. This gender gap varies by political party. Among Democrats this

\footnotetext{
${ }^{2}$ Corporations are better suited to having investors, are more likely to be employer firms, and are less likely to be used as pass-through entities than LLCs.
} 
gap is $14 \%$ smaller than the gap among independents, while among Republicans it is $24 \%$ larger. Moreover, male entrepreneurs are more sensitive to political regime changes than female entrepreneurs. Relative to their respective means, men are $3.8 \%$ less likely to engage in entrepreneurship when politically mismatched with the president, but for women this likelihood is only $1.5 \%$ lower.

We also find substantial heterogeneity of effects by age and income. The startup decisions of the youngest individuals (18 to 29 years old) are the most sensitive to regime changes. Their propensity to start a business is $7.4 \%$ of their mean lower when politically mismatched; among the oldest individuals (50 to 70 years old), this number is only $2 \%$. Moreover, while lower income households are in general less likely to start a business (an annual probability of $0.35 \%$ versus $0.77 \%$ ), they are more more responsive to political regime changes, with an effect size of $4.2 \%$, compared to $2.9 \%$ for higher income households.

While the evidence thus far compares individual Democrats to Republicans within the same county, we can also compare Republican-leaning counties to Democratic-leaning counties under changing presidential regimes. By comparing counties we lose the precise identification we have at the individual level, but there are advantages. First, county level data are available for almost all states. Second, more economic data exist at the county level, such as job creation and firm closures, so that we can better understand how the startup decisions of partisans aggregate up at the level of local economies following elections.

Figure 5 compares Republican to Democratic counties before vs. after the 2008 and 2016 presidential elections in a DID framework. The same pattern emerges: start-up rates in Democratic counties rise (relative to Republican ones) after the election of Barack Obama and fall after the election of Donald Trump. Specifically, following the 2008 election the startup rate in Democratic (relative to Republican) counties rose by $2.3 \%$ of the mean over the year; for the 2016 election, the corresponding increase was $4.0 \%$ for Republican counties. Extrapolating across all counties, this change corresponds to a partisan shift of 
approximately 45,000 new firms in the year following the 2016 election and 21,000 firms after the 2008 election.

Finally, we examine existing firms using the Business Dynamics Statistics data from the U.S. Census Bureau. These data also exist only at the county level. Despite using a different data source and focusing on a different firm population, we continue to find partisan effects. Existing firms in mismatched counties are less likely to open new establishments, more likely to close existing ones, and more likely to shut down the entire business, resulting in a net loss of jobs. For example, the net job creation rate of existing firms in counties mismatched with the party of the president is $6 \%$ of a standard deviation lower than in matched counties.

A possible driver of our findings is that the party in power implements policies favoring same-party entrepreneurs. To examine this, we estimate effects within geography and within industry. While policy is often focused on specific geographies or industries, we find strong partisan effects both within finely-grained geographic units (including within census block groups) and across almost all two-digit NAICS industries, including the least policy sensitive industry: retail (Hassan et al., 2019). Taken together, the evidence is inconsistent with partisan policy being the sole driver of our estimated effects. Another potential explanation for the evidence runs through partisan swings in economic sentiment around elections. While this is difficult to conclusively establish, we find circumstantial evidence. First, we find a partisan swing in economic expectations among business owners in Gallup survey microdata which mirrors the patterns in entrepreneurship we document. Second, we find the largest entrepreneurship responses in counties whose economies are most correlated with the national economy.

Overall, the effects we find aggregate up into a substantial component of economic activity. Between 2005 and 2017, we estimate a partisan shift of around 170,000 new firms, which is approximately the total number of firms created in the state of Mississippi over the same period. These new firms also contribute to local employment growth, consistent with the 
evidence in Adelino et al. (2017) and Glaeser et al. (2015). We estimate a shift of around 2.4 million jobs across Republican and Democratic counties, or $2 \%$ of average annual employment over the sample period. Critically, these economic changes are not evenly distributed: some states and counties see entrepreneurship spike, along with the associated job creation and investment flows, while others experience a decline. In short, we document a shifting of economic dynamism across political geographies in the wake of major elections, with downstream implications for labor markets, productivity dynamics, and regional inequality (Haltiwanger et al., 2013, Decker et al., 2014, Clementi and Palazzo, 2016). Understanding and anticipating these effects could improve place-based policies (Kline and Moretti, 2014), which are of increasing interest given the declining trend in US business dynamism and job reallocation since the 1980s (Decker et al., 2016).

Contribution to the literature. Our findings relate to several strands of the literature in entrepreneurship and political economy. In entrepreneurship, many have explored the links between the decision to start a firm and founder characteristics such as age, race, wealth, and gender (e.g., Evans and Jovanovic, 1989, Holtz-Eakin et al., 1994, Hurst and Lusardi, 2004, Guzman and Kacperczyk, 2019, Azoulay et al., 2020, Fairlie et al., 2021, Bellon et al., 2021, Bernstein et al., 2022b). Our paper shows that political affiliation is an important characteristic, representing $38 \%$ of the size of the well-known gender gap in entrepreneurship even after controlling for founder age, gender, race, geography and time.

A related line of inquiry examines how entrepreneurship relates to founder psychological characteristics such as cognitive skills, individualism, risk-tolerance and optimism (e.g., Puri and Robinson, 2013, Levine and Rubinstein, 2017, Kerr et al., 2019, Pástor and Veronesi, 2020, Barrios et al., 2021). These characteristics are generally viewed as static throughout adulthood; for example, Astebro et al. (2014) notes that "optimism is considered to be a ... stable individual trait." We provide evidence of time-varying economic optimism among business owners induced by partisan sentiment. 
We also contribute to the literature exploring determinants of the entrepreneurship decision. Existing work has focused on the impacts of financial constraints, risk-reduction policies, training, and entrepreneurial peers. ${ }^{3}$ We uncover a new driver of entrepreneurial entry - political sentiment - of comparable magnitude to existing shock-based estimates. For example, our political mismatch effects on entrepreneurship are similar to estimated effects of unemployment insurance reform (Hombert et al., 2020), access to reproductive healthcare (Zandberg, 2021), and the introduction of ride-sharing (Barrios et al., 2022). ${ }^{4}$ Critically, our shock is correlated across founders and time, thus contributing to the business cycle.

Finally, our paper contributes to a new literature on the economic consequences of partisanship. At the corporate level, several papers have found evidence of partisan effects on credit ratings, syndicated lending, and the composition of employees (Kempf and Tsoutsoura, 2021, Dagostino et al., 2020, Fos et al., 2021, Colonnelli et al., 2022). At the household level there is strong evidence from surveys that partisanship affects economic optimism around elections (e.g., Bartels 2002, Evans and Andersen 2006). However, there is mixed evidence that such optimism matters for important economic outcomes. Some papers report a link between spending on consumer goods and political alignment (Gerber and Huber, 2009, Gillitzer and Prasad, 2018, Benhabib and Spiegel, 2019), while others argue against this connection (McGrath et al., 2017, Mian et al., 2021). ${ }^{5}$ We provide evidence that a key driver of economic activity - new firm formation - changes in response to partisan sentiment.

\footnotetext{
${ }^{3}$ For financial constraints see, for example, Bertrand et al. (2007), Kerr and Nanda (2009), Chatterji and Seamans (2012), Robb and Robinson (2014), Kerr et al. (2015), Adelino et al. (2015), Schmalz et al. (2017). For risk reduction, training and peers see Gottlieb et al. (2021), Karlan and Valdivia (2011), Drexler et al. (2014), Fairlie et al. (2015), Fehder and Hochberg (2019) and Lerner and Malmendier (2013), Nanda and Sørensen (2010).

${ }^{4}$ Our estimated political mismatch effects range from 3 to 10\%. Zandberg (2021) shows that a one standard deviation increase in access to abortion predicts a $5.9 \%$ increase (relative to the mean) in the probability a woman becomes an entrepreneur. Hombert et al. (2020) shows that following pro-entrepreneurship unemployment insurance reform in France, new firm creation increased by around $10 \%$ relative to the pre-period. Finally, Barrios et al. (2022) shows that the introduction of ride-sharing, by providing a fallback option in case of failure, increased entrepreneurship by 3 to $6 \%$.

${ }^{5}$ Recent papers link partisanship with household decisions such as tax evasion, stock market trading, retirement investing, fertility, and residential sorting (Cookson et al., 2020, Cullen et al., 2021, Meeuwis et al., 2022, Dahl et al., 2022, Bernstein et al., 2022a, McCartney et al., 2021).
} 
The rest of the paper proceeds as follows. Section 2 describes the data. Section 3 provides evidence from individual data; section 4 examines evidence at the county level; and section 5 explores potential mechanisms. Section 6 concludes.

\section{DATA AND SAMPLE}

\subsection{ENTREPRENEURSHIP DATA FROM BUSINESS REGISTRATIONS}

We measure new firm formation using business registration records, the legal filings required to establish a new corporation, partnership, or limited liability company in the United States. Firms register in the jurisdiction of their choice, a sort of statutory domicile, as well as in states in which they engage in meaningful business activity. In practice, firms tend to choose either the state of their headquarters or Delaware as their jurisdiction, with the latter favored by growth-oriented firms because of its corporation law and court system.

We use data from the Startup Cartography Project (Andrews et al., 2020), which contains business registration records across 49 U.S. states and Washington D.C. from 1988 to 2017. The data includes the name of the firm, the firm type (corporation, LLC, or partnership), the address of record, and the jurisdiction (Delaware or local). We focus on for-profit firms and assign them to the state of their headquarters, independent of their state of jurisdiction. 33 states also include information on the names and titles of firm directors and detailed firm location; we focus on these states for our individual-level analysis. To ensure individuals are startup founders, we exclude personnel whose titles imply that they play only an administrative role. ${ }^{6}$ Since the data are business registrations, sole proprietorships and self-employed

\footnotetext{
${ }^{6}$ The titles we exclude are: incorporator, applicant, secretary, clerk, treasurer, director, and general partner. We also exclude names that appear in more than five different firm registrations in a year, as they are unlikely to have an operative role. Our results remain quantitatively similar when we do not impose these restrictions. We also exclude lawyers and other forms of registered agents. $78 \%$ of our founders have the following titles: President, Manager (of LLCs), CEO, CFO, Managing Director, Vice-President, Owner, Organizer, and Member. The remaining titles are idiosyncratic and state-specific; for example, Agent is the only title registered in Colorado and Montana.
} 
individuals without formal registration are not in our sample.

\subsection{VOTER AND DONOR DATA}

We use data on registered voters from L2, a leading non-partisan data vendor used by political campaigns and the academic literature (e.g., Allcott et al., 2020, Brown and Enos, 2021, Billings et al., 2021, Bernstein et al., 2022a, Spenkuch et al., 2021), for the 33 states for which we have sufficient information on firm founders to permit accurate matching. ${ }^{7}$ For 21 of these states, L2 assigns political affiliation using self-reported voter registration. For the remaining states, L2 infers party identification using a variety of data sources, including voter participation in primaries, demographics, exit polling, and commercial lifestyle data. Roughly $43 \%$ of entrepreneurs in our sample are in these states. ${ }^{89}$ For most analyses we compare Republicans to Democrats because they have clear directional sentiment. However, in Table 2 and Figure 3 we compare both groups to registered Independents.

L2 has complete coverage of the U.S. voter population starting in 2014. To minimize concerns over survivorship bias and reverse causality, we use the 2014 voter roll to assign voter partisanship. This strategy resolves such concerns for the 2016 election, and mitigates them for the 2008 election to the extent possible with L2 data. Party status is largely stable: the annual probability of changing from Republican to Democrat or vice versa is $1.8 \%$. We add individuals' voting histories, which we need to construct political activeness measures,

\footnotetext{
${ }^{7}$ These states are: Alabama, Alaska, Arizona, Arkansas, California, Colorado, Connecticut, Florida, Georgia, Hawaii, Idaho, Indiana, Iowa, Kentucky, Louisiana, Massachusetts, Minnesota, Mississippi, Missouri, Montana, New Mexico, Ohio, Oregon, Pennsylvania, Rhode Island, Tennessee, Texas, Utah, Vermont, Virginia, Washington, West Virginia, Wyoming.

${ }^{8}$ These states are: Alabama, Georgia, Hawaii, Indiana, Minnesota, Missouri, Montana, Ohio, Texas, Vermont, Virginia, Washington. L2's party inference varies according to features in each state. For example, in states like Georgia, Indiana and Texas, where the state provides voter participation in party primaries, L2 uses participation in these primaries to infer political party. However, in states like Minnesota, Missouri and Montana, where states provide no information that indicates likely party affiliation, L2 models each voter's party based on characteristics it collects independently.

${ }^{9} \mathrm{~L} 2$ data is subject to repeated testing by political campaigns in the field. In addition, academic papers have also verified the accuracy of voter file partisanship measures: Bernstein et al. (2022a) validates the accuracy of L2 partisanship by comparing partisanship in state files to L2 data; Brown and Enos (2021) runs a survey to verify L2 partisanship; Pew (2018a) compares voter file data to Pew national survey microdata.
} 
from the most recent L2 voter file we have (October 2020) to the 2014 voter population, dropping those without this data. ${ }^{10}$ Baseline results are similar if we keep such voters.

We use L2 data on voting history and political donations to identify more politicallyactive individuals. We define individuals as active voters if the share of even-year general and primary elections they have voted in by 2020 (out of elections they were eligible for) exceeds their party's sample median, which is about half of elections. L2 has two variables which describe political donation behavior. The first is a variable identifying donations recorded by the Federal Election Commission (FEC). Using the L2-linked FEC data, we call individuals active FEC donors if they have made a political donation by 2020 (2.3\% of the sample). L2 also identifies individuals whose household members have made a contribution to any political cause as of 2020 , which we call active household donors (40\% of our voters).

L2 provides a suite of demographic variables, such as registered state and county, age, gender, and race/ethnicity, which we use as controls in the main specifications. ${ }^{11}$

We obtain county-level vote share in presidential elections from the MIT Election Data and Science Lab (MIT, 2018).

\subsection{SAMPlE OF REGistered VOTERS}

We begin by keeping all voter-year observations in which individuals are between 18 and 70. We then match voters to firm founders in the business registration database by name and county. To perform this match we further focus on voters whose combination of first and last names is unique in the L2 data among all voters in a county. We use unique names because no other common identifier (e.g., home address or social security number) exists in both the voter and founder datasets to enable matching. However, name uniqueness

\footnotetext{
${ }^{10}$ Voting history is only attached to the data starting with the 2018 voter file, but is comprehensive for each voter.

${ }^{11}$ In some states voters report their race as part of voter registration, but in others L2 infers race data; race is missing for $15 \%$ of the regression sample. Bernstein et al. (2022a) validates L2's race data using HMDA; Pew (2018a) finds high levels of accuracy for commercial voter registration data on race by matching to their national panel survey microdata.
} 
within the voter database does not guarantee uniqueness among all county residents, because some people are non-registrants. Therefore, we further require the probability of a first and last name combination appearing among non-voters in a county to be below $0.1 \mathrm{pp} .{ }^{12}$ In Appendix Table A5 we consider other cutoffs - .05pp, .01pp, .001pp and .0001pp - which substantially increases the uniqueness of names and thus the precision of our matches. These more restrictive cutoffs do not change our results.

A sample of names that are unique at the county level will oversample women, because American women have a considerably wider range of first names than men (Wilson, 2016). It may also over or undersample other population sub-groups. To mitigate this concern, we show results that weight individuals in our sample so as to match observable characteristics of the full U.S. voter population (political party, education, race/ethnicity, and birth cohorts within each party). We also present our main analysis separately for men and women. In section 3.3.2 we discuss the representativeness of the sample and compare its characteristics to those of all US voters and to voters in sample states (see Table A1).

L2 has 140 million registered voters in the 33 states for which we have data on firm founders and addresses. After restricting the sample to unique names (within a county) as described we have around 40 million voters. Of these, 1.9 million (4.6\%) started a company during our sample period. Conditional on both voter and founder having middle initials (M.I.), the matched individuals have the same M.I. 90\% of the time, indicating a high match quality between voter and founder databases. Note that there are many reasons why M.I. may fail to match (as the SCP does not have a dedicated M.I. field, and because marriage sometimes triggers name changes that are recorded as middle names). Recoding cases with mismatched M.I. as non-founders (4.5\% of voter-founder matches, because many do not

\footnotetext{
${ }^{12}$ Estimating this likelihood requires assumptions about unregistered individuals. First, we assume the probabilities of first and last name combinations are the same across registered and non-registered individuals. Second, we assume those probabilities are the same across geographies. With these assumptions we calculate the probability of each first and last name combination in each county among non-registered individuals using the binomial formula.
} 
have middle names) does not meaningfully affect our estimates (see Appendix Table A6), as matching errors are likely to cause attenuation bias in our setting. ${ }^{13}$

A voter is coded as starting a business in a period if they register at least one firm in that period. The resulting sample is a voter-time panel with approximately 40 million observations at any point in time. For computational tractability we collapse the regression sample to a set of fully saturated county-party-characteristic-time cells, where each cell is a combination of county, party identification (Democrat, Republican, other), gender (male, female), age (18-29, 30-29, 40-29, 50-29, 60-70), race/ethnicity (white, Black, Hispanic, Asian, or missing), and time (either calendar year or year-month). Because all variables are categorical indicators, this approach generates identical regression estimates and standard errors to those obtained from regressions using individual data (Theil, 1954).

\subsection{DesCRIPTIVE STATISTICS}

Table 1 reports summary statistics on the annual likelihood of starting a business and the probability of ever starting a business during our sample period. It also reports the distribution of the sample across political parties and demographics, as well as the likelihood of starting a business in these subgroups. The political demographics of our sample appear broadly consistent with those of voters in general and by party. For example, female voters are more likely to be Democrats, as are younger individuals and minorities (Pew, 2018b). We further discuss the representativeness of our sample in Section 3.3.2.

Out of over 40 million voters in our sample, around $4.6 \%$ started a business at some point

\footnotetext{
${ }^{13}$ To cause estimates to be biased away from zero we would need matching errors to be correlated with partisanship, with the probability of starting a firm, and election outcomes; e.g., that we systematically (mis)match independents more likely to start firms with registered Democrats after 2008, but not after 2016. Moreover, we also estimate county-level results which mirror the individual-level results but do not require any matching. Note also that we cannot use M.I. as a matching criterion because, unlike for voter registration, only $45 \%$ of individuals in our 33 SCP states have recorded M.I., and this fraction varies from $0.1 \%$ to $60 \%$ across states, indicating a large discrepancy in recording M.I. across states. Were we to use M.I. for matching we would be applying a higher bar to individuals in states that record M.I. diligently compared to those in states that do not (and similarly within states, to people with middle names vs. those without).
} 
between 2005 and 2017. The likelihood of starting a business in a given year is approximately 0.5 pp. ${ }^{14}$ When we split the data by political party, a consistent theme emerges: Republicans are more likely to start a business than Democrats. For example, while $5.5 \%$ of Republicans ever start a firm in our data, only $3.7 \%$ of Democrats do. In a given year, the probability that a Republican starts a business is $0.6 \%$, while for a Democrat this is $0.4 \%$.

When we examine the entrepreneurship rate across demographic characteristics, we note a few differences. First, consistent with prior results in Fairlie et al. (2021), whites are more likely to start a business in a year than Blacks and Hispanics, as are college graduates (Hurst and Lusardi, 2004). Second, the entrepreneurship rate is the highest in the middle of our age distribution (between 30 and 49 years old), with a $0.7 \%$ chance of starting a business in a year, consistent with the pattern described in Azoulay et al. (2020) using U.S. Census Bureau data. As expected, higher income individuals are more likely to start a firm (Evans and Jovanovic, 1989). Finally, men are more than twice as likely to start a firm in a year than women, an estimate similar to previous work on the gender gap in entrepreneurship (e.g., Guzman and Kacperczyk, 2019).

To move beyond summary statistics, in Table 2 we estimate regressions of the likelihood of starting a business as a function of party affiliation and demographic characteristics. All regressions include county-year fixed effects. Column (1) estimates that Democrats are $0.08 \mathrm{pp}$ less likely to start a business in a year, relative to political independents, while Republicans are 0.16 pp more likely. This Republican-Democrat spread in startup likelihood is substantial, amounting to $49 \%$ of the outcome mean.

Column (2) adds age controls and confirms the evidence that individuals are most likely to start firms between the age of 30 and 49. However, adding age controls does little to change the partisan entrepreneurship gap. Column (3) supports previously-established patterns in

\footnotetext{
${ }^{14}$ The fraction of voters ever founding a firm $(4.6 \%)$ is smaller than the annual startup rate multiplied by the number of sample years $(0.5 \%$ x 13$)$ because serial entrepreneurs start firms in more than one year. They make up $18.4 \%$ of all entrepreneurs in our sample (similar to Lafontaine and Shaw, 2016).
} 
gender and entrepreneurship: men are over $0.4 \mathrm{pp}$ more likely to start a business in a year than women, all else equal, which is nearly $90 \%$ of the mean likelihood. After controlling for gender, the partisan entrepreneurship gap shrinks slightly from 49 to $39 \%$ of the mean, reflecting that men are disproportionately entrepreneurs and Republicans. Column (4) adds controls for race and shows that Asian voters are $90 \%$ of the mean more likely to start a business than whites. Column (5) further adds controls for education - college graduates are substantially more likely to start new firms - and column (6) shows that this is true also for those in the highest income bracket. After controlling for all of these covariates which correlate with political party and so may partially absorb the differences of interest - the partisan entrepreneurship gap remains large (at $26 \%$ of the mean) and statistically significant. ${ }^{15}$

Finally, columns 7 and 8 explore how political party interacts with the gender and racial entrepreneurship gaps in the literature. Column (7) interacts party with gender and shows that the gender gap among Independents is similar to the mean, while Democrats have a $14 \%$ smaller gap and Republicans have a $24 \%$ larger one. Column (8) examines the relationship between political party and the racial gap in entrepreneurship. Registered Independent Blacks are significantly less likely to start a business compared to whites (by $20 \%$ of the mean), but this difference falls by half among Black Republicans. Asians are significantly more likely to start a business compared to whites (by $71 \%$ of the mean), with no significant difference between Democratic and Republican Asians.

Overall, our sample appears to map well to general patterns of entrepreneurship in the U.S. while providing new facts about the relationship between entrepreneurship and political identity. Republicans are more likely to start firms than Democrats, even after controlling for individual characteristics and county-year fixed effects. Moreover, well-known gender and

\footnotetext{
${ }^{15}$ Our L2 voter file also provides the education and household income data we use here. However, as this data is imputed and lacks high-quality literature-based verification, we do not include these two variables in our baseline specification.
} 
racial gaps in entrepreneurship differ between Republicans and Democrats.

\section{Evidence From Individual Data}

\subsection{Elections And optimism}

To motivate our analysis, consider Figure 1 which plots the difference in economic views of Republicans and Democrats via Bloomberg's Consumer Comfort Index (CCI). The index is constructed from a telephone survey of 1,000 individuals (250 individuals per week for 4 weeks) and reported as a four-week rolling average. Respondents are asked to rate the national economy, their personal finances, and the buying climate on a scale from Excellent to Poor. Bloomberg aggregates their answers into a 0-100 point index. As Figure 1 demonstrates, the difference in CCI between Republicans and Democrats varies significantly across political regimes. For example, the average CCI of Republicans was almost two standard deviations higher than that of Democrats during the Republican administrations of George W. Bush and Donald Trump, but it was lower than the CCI of Democrats during the administration of Barack Obama.

In addition, there are sharp swings in the views of Republicans and Democrats after party-changing presidential elections, especially after those of Obama (2008), Trump (2016) and Biden (2020). ${ }^{16}$ Non-party-changing elections and midterms appear to have little to no effect on economic optimism. Mian et al. (2021) finds that the explanatory power of political party for economic expectations over the last 25 years has increased four-fold. Using the University of Michigan Survey, Meeuwis et al. (2022) reports that while Republicans' expectations for national business conditions increased (and Democrats' decreased) following the 2016 election, partisan expectations of their own economic situation remained essentially

\footnotetext{
${ }^{16}$ There is a decline in relative Republican optimism in the 12 months before the 2008 election, suggesting some anticipation of candidate Obama's victory. This is consistent with his lead in prediction markets prior to the 2008 election.
} 
unchanged. Meeuwis et al. (2022) also reports little change in the savings rate of partisans. Taken together, the swings in economic optimism around elections likely reflect partisan updating about the national economy rather than individual economic prospects.

Entrepreneurship is a future-oriented activity, so an entrepreneur's decision to start a business is necessarily tied to their belief about the current and future economic climate (e.g., Bengtsson and Ekeblom 2014). Given the survey evidence of stark differences in beliefs between Republicans and Democrats across political regimes, especially around partychanging elections, we examine whether entrepreneurship follows these same patterns.

\subsection{INDIVIDUAL-LEVEL EVENT-STUDY EVIDENCE}

We begin by comparing the changes in Republican individuals' likelihood of starting a firm relative to that of Democrats in an event study DID framework. In what follows, we contrast individuals of different political parties within the same county around presidential elections. This allows us to avoid confounding factors that may differentially affect Republican or Democratic areas. Moreover, we can control for founder characteristics associated with entrepreneurship, such as gender, age, and education.

The outcome is the excess likelihood that an individual starts a business in a month. ${ }^{17}$ We then estimate the following OLS regression:

$$
\mathrm{Y}_{i t}=\sum_{t=-8}^{7} \beta_{t} \times D e m_{i}+\gamma^{\prime} \mathbf{X}_{\mathbf{i t}}+\alpha_{c(i), t}+\epsilon_{i t}
$$

$Y_{i t}$ is the excess likelihood of individual $i$ starting a business in time $t$, the number of time periods relative to the presidential election month. We define $t=0$ as the three-month period following an election month and omit $t=-2$ as the base period. Our treatment variable is

\footnotetext{
${ }^{17}$ Because we are estimating within-year (quarterly) coefficients, seasonality is an important confounder. To address this we deseasonalize the likelihood of starting a firm by subtracting the party-specific county $x$ month-of-year average, and county annual trend using data starting from 2004 (for the 2008 election) or 2012 (for the 2016 election). We cannot use party-time fixed effects because they absorb the effect of interest.
} 
$D e m_{i}$, which equals one if individual $i$ is a Democrat and zero if they are Republican (see section 2.2 for partisanship definitions). We include county $\times$ time fixed effects $\alpha_{c(i), t}$ to control for county-specific time-varying startup likelihood. $\mathbf{X}_{\mathbf{i t}}$ is a vector of gender, race, and age group bins. ${ }^{18}$

Our coefficients of interest are $\beta_{t}$, which identify the impact of presidential elections on the likelihood of starting a business among Democrats (relative to Republicans) living in the same county and time around party-changing elections.

Our results indicate that individuals adjust their propensity to start firms along party lines in response to political regime changes. Figure 2 plots the $\beta_{t}$ coefficients, comparing the likelihood of starting a business among Republicans to the likelihood among Democrats with the same demographics living in the same county, before versus after the 2008 and 2016 presidential elections. Appendix Table A2 reports regression coefficients.

Following the election of President Obama in late 2008, Democrats immediately increase their startup likelihood relative to Republicans, an increase of $3.4 \%$ of the mean over 12 months. Extrapolating across the U.S., this represents a narrowing of the RepublicanDemocrat entrepreneurship gap by around 13,000 entrepreneurs. ${ }^{19}$ There is no indication of a differential pre-trend. For the 2016 presidential election the estimates for the pre-period in Figure 2 also support the assumption of parallel trends. Following the election, Republicans' startup probability rose by $2.4 \%$ of the mean relative to Democrats over 12 months, increasing the entrepreneurship gap by around 11,000 founders.

The entrepreneurship response we document is immediate, appearing in the same quarter of the Donald Trump election and the in the quarter following the Barack Obama election.

\footnotetext{
${ }^{18}$ Among our individual characteristics only the age group is potentially time varying. For computational tractability, we collapse the regression sample to fully saturated county-party-characteristic-month cells, weighting each cell by the number of individuals in it (see section 2.3 for details).

${ }^{19}$ The extrapolation, and those that follow, is obtained by multiplying the sum of coefficients in quarters 1 to 4 by three (to translate the monthly average to a quarterly total), multiplying by one-third of the U.S. population (assuming an equal share of Democrats, Republicans, and Independents), and dividing by 100 (to adjust the outcome unit from percentage point to one).
} 
The speed of the reaction is consistent with other work documenting new firm starts following shocks. For example, both Fazio et al. (2021) and Haltiwanger (2021) document large changes in firm formation that begin in the month following the onset of the COVID-19 pandemic in the U.S.

To understand the relative contributions of Republicans and Democrats to changes in the partisan entrepreneurship gap following presidential elections, we include Independents as the control group. Figure 3 plots the $\beta_{t}$ estimates for each party. The figure indicates that the decrease in the partisan entrepreneurship gap following the 2008 election is attributable to Republicans decreasing their rate of entrepreneurship relative to independents. By contrast, around 40 percent of the increase in the gap after the 2016 election comes from Republicans increasing their startup rate, and 60 percent comes from Democrats decreasing their rate.

\subsection{Partisanship AND Startups OVER The Full SAMPle}

Our DID event studies focus on the years immediately surrounding party-changing presidential elections and use less than half of the sample years as a result. In this section, we use the entire sample (2005-2017) to estimate the average relationship between entrepreneurship and being politically mismatched with the sitting president. To do so, we exploit the panel structure of our individual-level data and estimate the following:

$$
\mathrm{Y}_{i t}=\beta \text { Mismatch }_{i t}+\gamma_{D} \operatorname{Dem}_{i}+\gamma_{\mathbf{x}}^{\prime} \mathbf{X}_{\mathbf{i}}+\alpha_{c(i), t}+\epsilon_{i t}
$$

where $Y_{i t}$ is an indicator equal to one if individual $i$ starts a business in year $t$. Dem $i$ is an indicator equal to one for Democrats and zero for Republicans. Mismatch $i$ is an indicator equal to one when individual $i$ 's party identification differs from the party of the president in year $t$, namely one for Republicans during 2009-2016 and for Democrats during 2005-2008 and 2017. $\alpha_{c(i), t}$ denotes county $\times$ year fixed effects. We additionally control for $\mathbf{X}_{\mathbf{i}}$, a vector 
of demographic characteristics (gender, age, and race). Standard errors are clustered by county. ${ }^{20}$

The coefficient of interest is $\beta$, which estimates the average difference in the probability of starting a business when an individual's party affiliation is mismatched with that of the sitting president, relative to when their party is matched.

\subsubsection{MAin EStimates}

Table 3 panel A reports the estimates from equation 2. Column (1) uses all registered Republican and Democrat voters. The coefficient on Mismatch is negative and significant: individuals whose party is not in power are $0.017 \mathrm{pp}$ less likely than politically aligned individuals to start a business in a given year. This is a sizeable effect, equal to $3.3 \%$ of the sample mean. Extrapolating across the U.S., this amounts to an annual change in the partisan gap of around 13,000 founders, or approximately 170,000 over our 13-year sample.

To support the idea that it is political sentiment that drives differential entrepreneurship, we compare regular partisans to more active ones, i.e., those who vote more often or donate (see section 2.2 for definitions). Since active partisans are more invested in politics, we hypothesize that shifts in political power will have a stronger impact on their optimism and startup decisions. We add an indicator for active partisans (and interactions) to equation 2 and re-estimate the model. The negative and significant coefficient on Mismatch $\times$ Active in column (2) means that active voters are $0.01 \mathrm{pp}$ ( $2 \%$ of the mean) less likely to found a company than their less active counterparts in the same county and year when their party is not in power. In other words, the relationship between active voters' startup decision and political mismatch is $82 \%$ stronger than that of less active partisans. ${ }^{21}$

\footnotetext{
${ }^{20}$ For computational tractability we run the regression at the county-party-characteristic-year cell level. We weight each cell by the number of observations.

${ }^{21}$ Appendix Figure A1 plots the event study by election for active Republicans and Democrats. Effects for the 2008 election are stronger for active voters and somewhat stronger for the 2016 election.
} 
Turning to active donors, columns (3) and (4) indicate that household and FEC donor voters, respectively, are 0.007 and 0.04 pp less likely to start a company when mismatched, relative to their non-active counterparts. This represents an additional $1.4 \%$ and $7.3 \%$ of the average annual probability of starting new firms. While the effect for FEC donors is much larger, they are a selected, much smaller subset of registered voters: $2.3 \%$ of individuals are FEC donors while $50 \%$ are active voters and $40 \%$ are in donor households.

We view individuals who make an effort to donate to a political campaign as more likely to be actively involved in partisanship. A natural concern is that wealth and the propensity to donate are correlated, and the mismatch effect among wealthy people may be larger. In Appendix Table A3 we find no evidence for this concern when we re-run the specifications in Table 3 separately for individuals in above- and below-median income households. The mismatch effect and its interaction with all of our activeness measures in both income groups is similar to the full-sample estimates. If anything, we find stronger mismatch effects for below-median income households.

Taken together, the larger effects we find for active voters point towards partisanship driving the time-varying gap in entrepreneurship between Republicans and Democrats.

\subsubsection{Robustness of THE MAin ESTIMATES}

Next, we consider the representativeness of our sample. Recall that we focus on voters with unique names in a county to ensure an accurate match between the voter file and the business registration data. To examine how this unique-named sample compares to the full voter file, Appendix Table A1 reports individual characteristics for the full 2014 U.S. voter population (panel A - 160 million voters), for the 33 states which we can match to the SCP data (panel B - 108 million voters), and for voters in our regression sample (panel C - 40 million voters). Panels A and B are very similar, suggesting that the states in our sample are representative in terms of the voter characteristics we can measure. However, panel $\mathrm{C}$ 
displays some differences from the other two panels. This is likely the result of the unique name filter we use to generate our sample. For example, female and Black individuals are more likely to have unique names, while this is less likely for Hispanics.

To ensure that the differences between our sample and the U.S. voter population are not driving our reported results, in panel $\mathrm{B}$ of Table 3 we re-estimate the specifications in panel A using individual-level data and an entropy-balance method (Hainmueller, 2012) that weights each observation so that the means of covariates in the re-weighted sample match those in the U.S. voter population. ${ }^{22}$ For example, since our regression sample underrepresents men, this procedure will give more weight to male observations to correct for this. Estimates in panel B are very similar to the unweighted ones in panel A, providing support to the view that our estimates are representative of the underlying dynamics of partisan entrepreneurship. We report unweighted results in the remainder of the paper. Note also that we find consistent results at the county level (section 4.1) and when using the Census Bureau's Business Dynamics Statistics (section 4.2), both of which do not impose any name uniqueness constraints and cover 45 and 50 states plus DC, respectively.

As further robustness to our matching procedure, Appendix Table A5 presents estimates using progressively more stringent name rarity requirements i.e., replacing the $0.1 \mathrm{pp}$ threshold with $0.05 \mathrm{pp}, 0.01 \mathrm{pp}, 0.001 \mathrm{pp}$ and finally $0.0001 \mathrm{pp}$ ); results are unaffected. To ensure that observations for individuals whose middle initials do not match between the voter and founder datasets (approximately $4.5 \%$ of matched founders) are not affecting our results, we recode them as non-founders and replicate the specifications of Table 3 panel A in Appendix Table A6. Results are close to identical.

Finally, to address any concern that our match process operates more effectively in sparsely populated counties, we replicate Table 3 panel A using counties above approxi-

\footnotetext{
${ }^{22}$ The characteristics we match are share of Democrats and, within each party, the shares of men, Hispanics, Blacks, Asians, whites, and birth cohorts.
} 
mately the 95th percentile of county population (300,000 residents) in Appendix Table A7. Results are very similar.

\subsubsection{Heterogeneity By Gender, AGE, AND InCOME}

In Table 4 we begin by considering how partisan effects vary across gender because there is evidence that women's economic expectations react differently to those of men (e.g., Meeuwis et al. 2022, D'Acunto et al. 2020). Columns (1) and (2) of Table 4 replicate Table 3 column (1) for men and women separately. Men appear more sensitive to political power shifts than women. Relative to their respective means, men are $3.8 \%$ less likely to engage in entrepreneurship when politically mismatched with the presidential regime, but for women the effect is only $1.5 \% .^{23}$

In columns (3) to (5) we explore heterogeneity by age (Azoulay et al. 2020). Individuals between 18 and 29 years old show the largest effect relative to their mean $(7.4 \%)$, followed by those between 30 and $49(3.4 \%)$, while those between 50 and 70 respond the least $(2 \%)$. This monotonic decrease across age is consistent with partisanship-induced economic optimism: as entrepreneurs age they discount expected cash flows over shorter horizons.

Because wealth is correlated with the ability to start a business (e.g., Evans and Jovanovic, 1989, Fairlie, 1999, Hurst and Lusardi, 2004), columns 6 and 7 separately consider individuals with annual household incomes above and below $\$ 100,000$, respectively. While the mismatch coefficient is larger among high-income individuals, the relative effect is actually larger among low-income individuals (4.2 vs. 3.9\%); this difference obtains because, consistent with the literature, high-income individuals are more than twice as likely to start a business.

\footnotetext{
${ }^{23}$ Consistent with this, in Gallup daily survey data we find that the economic expectations of men react more strongly to regime changes than those of women.
} 


\subsubsection{HeTEROGENEITY BY FIRM TYPE}

We next consider the types of firms founded in our sample. Firm characteristics at founding predict firms' growth potential, survival, and contribution to employment, reflecting heterogeneity in founder ambitions and project potential (Schoar, 2010, Sterk et al., 2021). Guzman and Stern (2020) shows that firms founded as corporations instead of LLCs are three times more likely to go public or be acquired within six years of registration. For firms that file for a patent in their first year, this number jumps to 49 times. Guzman and Stern (2020) combines founding characteristics into a measure of "entrepreneurial quality" which we use to examine the ex ante quality of the entrepreneurship induced by partisan sentiment. $^{24}$

We begin by plotting firm quality as a function of party and gender in Figure 4 . The figure shows that Democrats are more likely than Republicans to start firms in the highest quality quintile. Moreover, men are more likely to start top-quality firms and less likely to start bottom-quality firms than women. In untabulated results, we find that these quality differences across gender and party persist even after we control for demographics and county $\times$ year fixed effects.

Next, we reconsider our main specification among firms of different ex ante quality. Specifically, Table 5 replaces the outcome variable of Table 3 with indicators for firm type. Column (1) examines LLCs, while column (2) focuses on corporations. We observe a larger coefficient on Mismatch for corporations: politically mismatched individuals are only $0.7 \%$ of the mean less likely to start an LLC compared to $10.7 \%$ for corporations.

Columns (3) to (5) focus on firm types that have high ex ante growth potential: VC

\footnotetext{
${ }^{24}$ In essence, this measure - also called the entrepreneurial quality index in Guzman and Stern (2020) uses the founding characteristics of startups available in the business registration records, such as corporate form, jurisdiction, name, and intellectual property to create out of sample estimates of the probability of achieving an equity outcome (i.e., IPO or acquisition). These estimates have a high predictive power: startups in the top $1 \%$ of the quality distribution account for $36 \%$ of the equity outcomes and the top $5 \%$ accounts for $53 \%$ of all equity outcomes, out of sample.
} 
backed, firms that filed for a patent, and firms in the top five percent of the Guzman and Stern (2020) quality distribution. Despite finding large economic magnitudes for the effect size ( $15.9 \%$ of the mean for VC-backed and $4.7 \%$ for patent firms), the rarity of these firm types limits power and hence the statistical significance of these estimates. However, firms in the top 5 percent by ex ante quality show a mismatch effect of $4.8 \%$ of the mean that is statistically significant.

Columns (6)-(10) consider quintiles of the quality distribution and show a near-monotonic decrease in the estimated sensitivity to mismatch as firm quality declines. For example, firms in the top quintile have a mismatch coefficient of -0.004 (6.4\% of the mean), while coefficients for firms in the fourth, third, second and first quintiles are $-0.003,-0.002,-0.001$ and -0.003 , respectively.

In summary, when looking across various measures, we find effects across the entire distribution of firm quality, and these are stronger among higher-quality firms and weaker among lower-quality firms. ${ }^{25}$

\section{Evidence from County-Level Data}

All the non-survey evidence thus far compares Republican vs. Democrat individuals within the same county across changing political regimes. In this section, we compare Republican vs. Democratic counties. There are both advantages and disadvantages with this level of analysis. The main disadvantage at the county level is that we lose the precise identification we have at the individual level, where we can compare the behavior of Republicans and Democrats within the same county when the party of the presidency changes. However, there are three advantages. First, county level data are available for almost all states, so we are not restricted to the 33 states for which we have firm founder data that we can match

\footnotetext{
${ }^{25}$ The large effects we find for high-quality firms may be related to the pro-cyclicality of growth entrepreneurship (Nanda and Rhodes-Kropf, 2013, Howell et al., 2020). If political mismatch reduces founders' expectations of the availability of future capital, it could lead to reduced entry among growth-oriented firms.
} 
to the voter roll. Second, with county data we do not need to impose the unique name constraint that was required to match founder and voter data. Third, more economic data exist at the county level - such as job creation and firm closures - so that we can better understand how partisans' startup choices aggregate up to the level of local economies, and whether there are effects on existing firms.

\subsection{County-Level evidence from the Startup Cartography Project}

Similar to our event study DID analysis at the individual level, in this subsection we compare Democratic versus Republican counties across 45 states, before vs. after the 2008 and 2016 elections. ${ }^{26}$

We classify a county as Democratic-leaning (and refer to it as a "Democratic county" for brevity) if its vote share for the Democratic party is above the sample median in the preceding presidential election, and Republican-leaning otherwise. ${ }^{27}$ The outcome of interest is the startup rate: the total number of new firms registered in a month per 100,000 county residents. If there are no new firms in a county $\times$ month, we code it as a zero. Because we are estimating quarterly (rather than annual) coefficients seasonality is an important confounder, so we de-seasonalize the startup rate by regressing it on county $\times$ month-ofyear indicators and county annual linear trends using data starting from 2004 (for the 2008 election) and 2012 (for the 2016 election). We refer to the resulting variable as the excess startup rate.

We use the following OLS specification:

$$
\mathrm{Y}_{c t}=\sum_{t=-8}^{7} \beta_{t} \times \operatorname{Dem}_{c}+\gamma^{\prime} X_{c t}+\alpha_{c}+\alpha_{t}+\epsilon_{c t}
$$

\footnotetext{
${ }^{26}$ We drop MI, NV, ME, AL and DC (leaving us with 45 states) because we are unable to assign more than $50 \%$ of firms to counties in these states.

${ }^{27}$ Results are unaffected if we define county partisanship using the Republican vote share instead.
} 
$Y_{c t}$ is the excess startup rate in county $c$ in time $t$, the number of time periods relative to when each presidential election was decided, i.e., November 2008 and November 2016. Our treatment variable is $D e m_{c}$, which equals one if county $c$ is classified as Democrat-leaning, and zero otherwise. $X_{c t}$ includes the county annual unemployment rate, per-capita income, and the employment share in each two-digit NAICS industry (excluding non-classifiable establishments) as controls for contemporaneous economic conditions and industry importance in each county. We include county fixed effects $\alpha_{c}$ and event time fixed effects $\alpha_{t}$ to absorb the average startup rate in a county and national registration trends. We cluster standard errors by county.

While the data is monthly, for precision and clarity we estimate quarterly averages, and report the monthly version in the Appendix. We define $t=0$ as the three-month period following an election month. For example, November 2016 through January 2017 constitute $t=0$ for the 2016 election. We omit the indicator for $t=-2$ to form our base period.

Similar to the individual-level DID we interpret the $\beta_{t}$ coefficients as the causal effect of presidential elections on startups, assuming that Republican and Democrat-leaning counties would have moved in parallel in the absence of elections. As we will show, there are no differential pre-trends.

Figure 5 panels (a) and (b) plot the estimated $\beta_{t}$ coefficients. Mirroring our results in Figure 2, Democratic counties increase their startup rate relative to Republican counties following the election of President Obama, and Republican counties increase their relative rate after the election of President Trump. Specifically, Democratic counties on average see 19 more firms per 100,000 residents (2.3\% of the mean) relative to Republican counties in the year following the 2008 election. Republican counties experience a relative increase of 
39 firms per 100,000 residents (4.0\% of the mean) in the year following the 2016 election. ${ }^{28}$

Panels (c) and (d) repeat the previous analysis, except now we compare clearly Democratic and clearly Republican-leaning counties to more politically divided ones (so-called "purple counties") rather than to each other, in order to examine which areas are driving the election effects. We define purple counties as those with a victory margin of less than 10 percentage points in the preceding election. Both panels indicate that the county-level election effects are driven by Republican counties: they experience a sharp increase in their entrepreneurship around the 2016 election and a sharp decrease around the 2008 election. These results generally mirror what we found when comparing individual Republican and Democrat voters to Independents within the same county in Figure 3, especially around the 2008 election.

It is noteworthy that the county-level analysis obtains estimated effects in the same $2 \%$ to $4 \%$ range as the individual DID analysis, despite using a different source of variation (across county here vs. within county in Figure 2), a different sample (45 states vs. 33 states) and no unique-name constraint. We view the consistency as evidence of our main result's robustness.

\subsection{County-level evidence from Census}

As a third source of variation, we consider county-level data on existing firms from the Census Bureau's Business Dynamics Statistics (BDS), which covers all 50 states plus DC. Unlike new startups, the extensive margin of entrepreneurship, existing firms allow us to explore the intensive margin by examining how the expansion, contraction, and death of existing firms co-varies with the political alignment of their counties around elections.

\footnotetext{
${ }^{28}$ Appendix Figure A2 shows the same regression at a monthly frequency and provides strong support for the parallel trend assumption. In fact, we see that the slightly negative coefficient in quarter -1 for the 2016 election in Figure 5 is entirely driven by the month before the election (October 2016), a period of political turbulence which included FBI director Comey's letter to Congress about candidate Clinton's emails. In another robustness test, we drop contemporaneous economic controls from equation 3 and find quantitatively similar estimates (Figure A3).
} 
BDS reports the number of new and existing employer firms, the number of newly opened and closed establishments of existing firms, and the job creation rate by firm age bins, for every county and year through 2018. We run the following regression:

$$
\mathrm{Y}_{c t}=\beta \text { Mismatch }_{c t}+\gamma^{\prime} \mathbf{X}_{\mathbf{c t}}+\alpha_{c}+\alpha_{t}+\epsilon_{c t}
$$

where $Y_{c t}$ is a variable of interest from BDS, such as the annual number of new firms, newly opened or closed establishments of existing firms, and firm deaths, per 100,000 county residents (20 years or older) in county $c$ in year $t$. Mismatch $h_{i t}$ is an indicator equal to one when the partisanship of county $c$ differs from the party of the sitting president in year $t$. County partisanship is defined in section 4.1. We include a vector of county-level, timevarying variables $X_{c t}$, i.e., annual unemployment rate, annual per-capita income, and the employment share of each two-digit NAICS industry (excluding NAICS=99) to control for economic conditions and industry importance in the county. When the outcomes are for existing firms, we include firm age bin fixed effects. ${ }^{29}$ We also include county fixed effects $\alpha_{c}$ and year fixed effects $\alpha_{t}$ to absorb any persistent difference across counties and a national trend in business dynamics.

The coefficient of interest is $\beta$, which estimates the average difference in business dynamics in counties that are mismatched with the party of the sitting president, relative to those in aligned counties.

Table 6 reports the estimates from equation 4. Column (1) confirms our earlier results for startups in a different dataset. It shows that there are around five fewer new firms per 100,000 county residents in politically mismatched counties relative to matched ones, amounting to $2.9 \%$ of the outcome mean. In terms of economic magnitude, the relationship

\footnotetext{
${ }^{29}$ Because the BDS data are counts and rates in bins at the county-year level, we cannot include any other firm-level controls. However, we do include county-level controls, as described in the text. Note that our results are robust to excluding contemporaneous economic controls: see Table A12.
} 
between a county's political misalignment and new firm creation is roughly equivalent to a $2.2 \mathrm{pp}$ increase in the local unemployment rate, using the coefficient on Unemp(\%) from the table. Column (2) indicates that there is no economic or statistical difference in the job creation rate of new firms between matched and mismatched counties, implying that new firms that are born during aligned periods have, on average, the same number of employees as firms that begin during times of mismatch.

Turning to intensive margin effects, columns (3) through (5) show that firms in politically mismatched counties open fewer establishments (1\% of the mean), close more establishments (1.1\% of the mean), and experience more firm death (1.4\% of the mean), relative to those in matched counties. These business dynamics have implications for the labor market, as the net job creation rate (job creation minus destruction) in column (6) among existing firms in mismatched counties is $0.33 \mathrm{pp}$ of annual employment lower than in matched counties, amounting to around $30 \%$ of the mean or $6 \%$ of the standard deviation $(5.2) .{ }^{30}$ Summing across new and existing firms (column 7), politically mismatched counties experience a relative fall in their net job creation rate of $0.32 \mathrm{pp}$ of annual employment.

Aggregating up, we find that the extensive margin effects from columns (1) and (5) translate to approximately 82,000 new employer firms in politically matched counties (relative to mismatched ones), and the death of over 10,000 employer firms in mismatched counties over 13 years. ${ }^{31}$ The intensive margin effects in columns (3), (4) and (6) indicate a broader impact on business dynamism, amounting to 4,000 new establishments and 2.4 million net jobs in matched counties (relative to mismatched ones) over our sample period. ${ }^{32}$

\footnotetext{
${ }^{30}$ Note that because the net job creation rate is a net variable it has a near-zero mean, making it a poor benchmark - this is why we also compare our estimate to the standard deviation.

${ }^{31}$ Even though the effect (relative to the mean) of partisanship on entry using BDS data is similar to the main effect in Table 3, these aggregate estimates are substantially smaller because BDS data captures only employer firms.

${ }^{32}$ We calculate these numbers making the simplifying assumption that Republican and Democrat counties have the same average population and/or employment.
} 


\section{EXAMINING MECHANISMS}

\subsection{Mechanism: Policy}

A natural explanation for our findings is that regime switches lead to policies favoring individuals who are members of the party in power. For example, President Trump's 2017 Tax Cuts and Jobs Act included a state and local tax cap of $\$ 10,000$ which disproportionately hurt taxpayers in Blue States, while the 2010 Affordable Care Act may have benefited Democratic areas more than Republican ones.

While it is possible that policy changes contribute to our findings, our evidence is not consistent with an explanation that is solely policy-based. First, the DID event studies (Figure 2) show rapid effects on entrepreneurship, often within the first two quarters after an election. But policy takes time to design and implement, in contrast to expectations (about future policies or the economy as a whole) which can change almost immediately, as suggested by Figure 1. Second, we find stronger effects among the most partisan individuals (Table 3), i.e., those that vote more or donate. It is unclear, for example, why a new federal policy would favor Republicans who vote more often than other Republicans in the same county. But it seems likely that an active Republican would be especially optimistic (pessimistic) during Republican (Democratic) administrations. Third, we find significant

heterogeneity by personal characteristics (Table 4), with men and younger people showing larger effects. Again, it seems unclear why a new policy would disproportionately favor, for example, young Democrats (relative to old ones) or Democratic men (relative to Democratic women) in the same county.

We further investigate a policy-based channel by conducting tests in two domains that policy often targets: geography and industry. Mian et al. (2021) finds little evidence of changes in tax rates, personal income growth, and transfers at the county and state levels 
around U.S. presidential elections. In addition, to examine whether partisans' economic situation differentially improves, they use zip code-by-month fixed effects, assuming that people within zip codes are subject to the same government policies. Similarly, we reestimate the model in Table 3, adding fine-unit geographic fixed effects so that identification comes, for example, via differences between Democrats and Republicans who live in the same census block group at the same time. If policy is targeted to geography, we would expect our main result to disappear as we include these fixed effects. However, we find little evidence that this is the case. In Appendix Table A4, we progressively add finer geographyby-year fixed effects, from state-level (column 1) to census block group-level (column 5). ${ }^{33}$ The point estimates under these alternative geography $\times$ year fixed effects are all similar to the estimates under the main specification shown in column (2). Moreover, to the extent that policies are different by income group (e.g., tax policies), geography fixed effects for zip, census tract, or block group would also absorb such targeting.

Turning to industry, we categorize companies into two-digit NAICS industries using a word-tagging approach based on company names - see Appendix section 6 for details. We identify the industry of $55 \%$ of firms in our sample in this way. We then run the same specification used in Table 3 column (1), but change the dependent variable to be an indicator for whether an individual starts a firm in a specific NAICS-2 industry. Table 7 presents results for the 13 most populated industries in the sample.

We observe effects for mismatched entrepreneurs across almost all industries, which is inconsistent with a pure policy-based mechanism. This is particularly true for retail, the industry with the lowest policy sensitivity according to Hassan et al. (2019). ${ }^{34}$ The robustness

\footnotetext{
${ }^{33}$ There are 10,000 people per zip code, 4,000 per census tract, and 1,500 per census block group, on average.

${ }^{34}$ We note that finding our result in policy-insensitive industries also argues against a different version of the policy hypothesis: one might imagine that policies affect everyone equally, but that one political party is more aware of them than another. Finding our main effect in industries with little policy dependence also argues against this view.
} 
of our result across industries is also consistent with the fact that our Mismatch estimates are quantitatively similar when we include census block group $\times$ year fixed effects (in Appendix Table A4). The latter can be seen as an approximation to industry $\times$ year fixed effects, because in our data the firms started by two founders in the same census block group and year on average have a 26 percent chance of being in the same industry.

\subsection{Mechanism: Economic optimism}

In light of the evidence indicating that policy cannot be the sole driver of our findings, we now consider partisan changes in economic expectations as a possible channel. While this is difficult to pin down conclusively, we present circumstantial evidence that is consistent with this mechanism.

First, recall that our motivating Figure 1 demonstrates sharp partisan swings in economic optimism among a nationally-representative survey following party-switching presidential elections over the past three decades. To show that similar patterns also exist among entrepreneurs, we utilize the Gallup U.S. Daily Survey. Gallup elicits the views of 1,000 U.S. adults daily from 2008 to 2013, and 500 a day from 2013 to 2016, on topics related to the economy, politics and their well-being. We focus on the 2008 presidential election because the number of respondents falls sharply after 2016, from 500 to only 30 per day. Importantly, respondents identify their political party (38\% are Democrats, 37\% are Republicans) and whether they are a business owner $(2 \%) .{ }^{35}$

In Figure 6, we show respondents' optimism about the economy and their well-being, separately for business owners and non-owners. Panel A plots the average response to the question "How would you rate economic conditions in this country today?" Panel B plots the share of respondents choosing "Getting better" to the question "Right now, do you feel your

\footnotetext{
${ }^{35}$ Business owners need not be business founders, but this is the closest population to entrepreneurs that is identifiable in the Gallup survey.
} 
standard of living is getting better or getting worse?" Both panels show that the optimism of Democratic business owners rises sharply after the 2008 presidential election and continues to rally in the following years, while the optimism of Republican business owners falls after the election and remains relatively flat until 2014. Moreover, compared to non-business owners, they appear to respond at least as much, or even more, to the 2008 election.

To further examine the economic optimism channel, we focus on the 2008 presidential election and examine whether counties that experience a larger rise in optimism after the election exhibit a stronger increase in entrepreneurship. To do so, we aggregate the optimism of respondents by MSA and year (because Gallup provides only MSA-level survey weights) and apply this optimism measure to each component county. We then adjust equation 3 by interacting the indicator for Democratic counties with indicators for whether the counties have an above- or below-median change in the two optimism measures between 2008 and 2009. The resulting DID coefficients are reported in Figure 7. Using Republican counties as the omitted group, Democratic counties with an above-median change in optimism after the 2008 election saw a greater increase in entrepreneurship than Democratic counties with a below-median change. In other words, we see the strongest partisan entrepreneurship effects in the counties with the largest increase in optimism around the election. ${ }^{36}$

Finally, recall that the motivating figure Figure 1 demonstrates partisan swings in optimism at the national level. However, most entrepreneurship depends on the local economy (e.g., Schoar, 2010). Thus, we would expect that localities whose economic growth is most connected to the national economy to be most affected by party-changing elections. In addition, we would expect partisan entrepreneurs in these areas to be most responsive to these elections. This is precisely what we find in Table A10: effect sizes monotonically increase with county correlation with the national economy.

\footnotetext{
${ }^{36}$ We caution that this evidence is only suggestive, as shifts in MSA optimism are determined after the election.
} 
Taken together, the swing in business owner sentiment along party lines around elections, and the larger effects observed in more ex post optimistic and more economically-connected counties all indicate that changes in economic expectations may contribute to partisan patterns in entrepreneurship.

\section{Conclusion}

This paper documents a relationship between political identity and entrepreneurship, with Republicans over $26 \%$ more likely to start a firm in a given year than Democrats, after controlling for a range of other characteristics. This partisan entrepreneurship gap is time-varying, widening when Republicans take control of the presidency and shrinking when Democrats do.

Our paper highlights that supporters of a political party exhibit consequential changes in economic behavior when their preferred regime comes to power. Thus, it has potentially different policy implications compared to prior work. Most of the existing literature focuses on political connections and allocation of government resources (e.g., Fisman, 2001, Faccio, 2006, Robinson and Verdier, 2013), with policy prescriptions aimed at reducing clientelism and regulatory capture. In contrast, the effect we document on supporters appears to arise organically, potentially via the economic optimism of partisans. It is not clear which policy actions would best mitigate the dampening economic effect on regions supporting the losing side, or whether such policies would be welfare-improving.

Finally, we find stronger partisan effects on entrepreneurship around recent party-changing elections, not only across Republican versus Democratic counties but also between Republican and Democratic individuals within the same county, zipcode, and even census block group. This aligns with the increasingly polarized responses to election outcomes, as well as broad increases in political polarization generally (Abramowitz and Saunders, 2008, 
Gentzkow et al., 2019, Alesina et al., 2020). If polarization continues to rise, will the role of political identity become more central to entrepreneurial decisions? We leave these questions to future research. 


\section{REFERENCES}

Abramowitz, A. I. and Saunders, K. L. (2008). Is polarization a myth? The Journal of Politics, 70(2):542-555.

Adelino, M., Ma, S., and Robinson, D. (2017). Firm age, investment opportunities, and job creation. Journal of Finance, 72(3):999-1038.

Adelino, M., Schoar, A., and Severino, F. (2015). House prices, collateral, and selfemployment. Journal of Financial Economics, 117(2):288-306.

Alesina, A., Miano, A., and Stantcheva, S. (2020). The polarization of reality. AEA Papers and Proceedings, 110:324-28.

Allcott, H., Braghieri, L., Eichmeyer, S., and Gentzkow, M. (2020). The welfare effects of social media. American Economic Review, 110(3):629-76.

Andrews, R. J., Fazio, C., Guzman, J., Liu, Y., and Stern, S. (2020). The startup cartography project. Working Paper.

Astebro, T., Herz, H., Nanda, R., and Weber, R. A. (2014). Seeking the roots of entrepreneurship: Insights from behavioral economics. Journal of Economic Perspectives, 28(3):49-70.

Azoulay, P., Jones, B. F., Kim, J. D., and Miranda, J. (2020). Age and high-growth entrepreneurship. American Economic Review: Insights, 2(1):65-82.

Barrios, J. M., Hochberg, Y., and Macciocchi, D. (2021). Rugged entrepreneurs: The geographic and cultural contours of new business formation. NBER Working Paper.

Barrios, J. M., Hochberg, Y. V., and Yi, H. (2022). Launching with a parachute: The gig economy and new business formation. Journal of Financial Economics, 144(1):22-43.

Bartels, L. M. (2002). Beyond the running tally: Partisan bias in political perceptions. Political Behavior, 24(2):117-150.

Bellon, A., Cookson, J. A., Gilje, E. P., and Heimer, R. Z. (2021). Personal wealth, selfemployment, and business ownership. Review of Financial Studies.

Bengtsson, O. and Ekeblom, D. (2014). The bright but right view? a new type of evidence on entrepreneurial optimism. Working Paper.

Benhabib, J. and Spiegel, M. M. (2019). Sentiments and economic activity: Evidence from US states. The Economic Journal, 129(618):715-733.

Bernstein, A., Billings, S. B., Gustafson, M. T., and Lewis, R. (2022a). Partisan residential sorting on climate change risk. Journal of Financial Economics.

Bernstein, S., Colonnelli, E., Malacrino, D., and McQuade, T. (2022b). Who creates new firms when local opportunities arise? Journal of Financial Economics, 143(1):107-130. 
Bertrand, M., Schoar, A., and Thesmar, D. (2007). Banking deregulation and industry structure: Evidence from the french banking reforms of 1985. Journal of Finance, 62(2):597628.

Billings, S. B., Chyn, E., and Haggag, K. (2021). The long-run effects of school racial diversity on political identity. American Economic Review: Insights, 3(3):267-84.

Brown, J. R. and Enos, R. D. (2021). The measurement of partisan sorting for 180 million voters. Nature Human Behaviour, pages 1-11.

Chatterji, A. K. and Seamans, R. C. (2012). Entrepreneurial finance, credit cards, and race. Journal of Financial Economics, 106(1):182-195.

Clementi, G. L. and Palazzo, B. (2016). Entry, exit, firm dynamics, and aggregate fluctuations. American Economic Journal: Macroeconomics, 8(3):1-41.

Colonnelli, E., Neto, V. P., and Teso, E. (2022). Politics at work. NBER working paper.

Cookson, J. A., Engelberg, J. E., and Mullins, W. (2020). Does partisanship shape investor beliefs? Evidence from the COVID-19 pandemic. Review of Asset Pricing Studies, 10(4):863-893.

Cullen, J. B., Turner, N., and Washington, E. L. (2021). Political alignment, attitudes toward government and tax evasion. American Economic Journal: Economic Policy.

Dagostino, R., Gao, J., and Ma, P. (2020). Partisanship in loan pricing. Working Paper.

Dahl, G. B., Lu, R., and Mullins, W. (2022). Partisan fertility and presidential elections. American Economic Review: Insights.

Decker, R., Haltiwanger, J., Jarmin, R., and Miranda, J. (2014). The role of entrepreneurship in US job creation and economic dynamism. Journal of Economic Perspectives, 28(3):3-24.

Decker, R. A., Haltiwanger, J., Jarmin, R. S., and Miranda, J. (2016). Declining business dynamism: What we know and the way forward. American Economic Review PP, 106(5):203-07.

Drexler, A., Fischer, G., and Schoar, A. (2014). Keeping it simple: Financial literacy and rules of thumb. American Economic Journal: Applied Economics, 6(2):1-31.

D'Acunto, F., Malmendier, U., and Weber, M. (2020). Gender roles and the gender expectations gap. Proceedings of the National Academy of Sciences.

Evans, D. S. and Jovanovic, B. (1989). An estimated model of entrepreneurial choice under liquidity constraints. Journal of Political Economy, 97(4):808-827.

Evans, G. and Andersen, R. (2006). The political conditioning of economic perceptions. The Journal of Politics, 68(1):194-207.

Faccio, M. (2006). Politically connected firms. American Economic Review, 96(1):369-386. 
Fairlie, R., Robb, A., and Robinson, D. T. (2021). Black and white: Access to capital among minority-owned start-ups. Management Science.

Fairlie, R. W. (1999). The absence of the African-American owned business: An analysis of the dynamics of self-employment. Journal of Labor Economics, 17(1):80-108.

Fairlie, R. W., Karlan, D., and Zinman, J. (2015). Behind the gate experiment: Evidence on effects of and rationales for subsidized entrepreneurship training. American Economic Journal: Economic Policy, 7(2):125-61.

Fazio, C., Guzman, J., Liu, Y., and Stern, S. (2021). How is COVID changing the geography of entrepreneurship? evidence from the startup cartography project. NBER working paper.

Fehder, D. C. and Hochberg, Y. V. (2019). Spillover effects of startup accelerator programs: Evidence from venture-backed startup activity. Working paper.

Fisman, R. (2001). Estimating the value of political connections. American Economic Review, 91(4):1095-1102.

Fos, V., Kempf, E., and Tsoutsoura, M. (2021). The political polarization of US firms. Working Paper.

Gentzkow, M., Shapiro, J. M., and Taddy, M. (2019). Measuring group differences in high-dimensional choices: method and application to congressional speech. Econometrica, 87(4):1307-1340.

Gerber, A. S. and Huber, G. A. (2009). Partisanship and economic behavior: Do partisan differences in economic forecasts predict real economic behavior? American Political Science Review, pages 407-426.

Gillitzer, C. and Prasad, N. (2018). The effect of consumer sentiment on consumption: Cross-sectional evidence from elections. American Economic Journal: Macroeconomics, 10(4):234-69.

Glaeser, E. L., Kerr, S. P., and Kerr, W. R. (2015). Entrepreneurship and urban growth: An empirical assessment with historical mines. Review of Economics and Statistics, 97(2):498520.

Gottlieb, J. D., Townsend, R. R., and Xu, T. (2021). Does career risk deter potential entrepreneurs? Review of Financial Studies.

Guzman, J. and Kacperczyk, A. O. (2019). Gender gap in entrepreneurship. Research Policy, 48(7):1666-1680.

Guzman, J. and Stern, S. (2020). The state of American entrepreneurship: New estimates of the quantity and quality of entrepreneurship for 32 US states, 1988-2014. American Economic Journal: Economic Policy, 12(4):212-43. 
Hainmueller, J. (2012). Entropy balancing for causal effects: A multivariate reweighting method to produce balanced samples in observational studies. Political Analysis, 20(1):2546.

Haltiwanger, J., Jarmin, R. S., and Miranda, J. (2013). Who creates jobs? small versus large versus young. Review of Economics and Statistics, 95(2):347-361.

Haltiwanger, J. C. (2021). Entrepreneurship during the covid-19 pandemic: Evidence from the business formation statistics. NBER WP.

Hassan, T. A., Hollander, S., Van Lent, L., and Tahoun, A. (2019). Firm-level political risk: Measurement and effects. Quarterly Journal of Economics, 134(4):2135-2202.

Holtz-Eakin, D., Joulfaian, D., and Rosen, H. S. (1994). Entrepreneurial decisions and liquidity constraints. Rand Journal of Economics, 25(2):334.

Hombert, J., Schoar, A., Sraer, D., and Thesmar, D. (2020). Can unemployment insurance spur entrepreneurial activity? Evidence from France. Journal of Finance, 75(3):12471285.

Howell, S. T., Lerner, J., Nanda, R., and Townsend, R. R. (2020). Financial distancing: How venture capital follows the economy down and curtails innovation. NBER Working Paper.

Hurst, E. and Lusardi, A. (2004). Liquidity constraints, household wealth, and entrepreneurship. Journal of Political Economy, 112(2):319-347.

Karlan, D. and Valdivia, M. (2011). Teaching entrepreneurship: Impact of business training on microfinance clients and institutions. Review of Economics and Statistics, 93(2):510527.

Kempf, E. and Tsoutsoura, M. (2021). Partisan professionals: Evidence from credit rating analysts. Journal of Finance.

Kerr, S. P., Kerr, W. R., and Dalton, M. (2019). Risk attitudes and personality traits of entrepreneurs and venture team members. Proceedings of the National Academy of Sciences, 116(36):17712-17716.

Kerr, S. P., Kerr, W. R., Nanda, R., et al. (2015). House money and entrepreneurship. NBER, (WP 21458).

Kerr, W. R. and Nanda, R. (2009). Democratizing entry: Banking deregulations, financing constraints, and entrepreneurship. Journal of Financial Economics, 94(1):124-149.

Kline, P. and Moretti, E. (2014). People, places, and public policy: Some simple welfare economics of local economic development programs. Annual Review of Economics, 6(1):629-662.

Lafontaine, F. and Shaw, K. (2016). Serial entrepreneurship: Learning by doing? Journal of Labor Economics, 34(S2):S217-S254. 
Lerner, J. and Malmendier, U. (2013). With a little help from my (random) friends: Success and failure in post-business school entrepreneurship. Review of Financial Studies, 26(10):2411-2452.

Levine, R. and Rubinstein, Y. (2017). Smart and illicit: who becomes an entrepreneur and do they earn more? Quarterly Journal of Economics, 132(2):963-1018.

McCartney, W. B., Orellana-Li, J., and Zhang, C. (2021). Political polarization affects households' financial decisions, evidence from home sales. Working Paper.

McGrath, M. C. et al. (2017). Economic behavior and the partisan perceptual screen. Quarterly Journal of Political Science, 11(4):363-83.

Meeuwis, M., Parker, J. A., Schoar, A., and Simester, D. I. (2022). Belief disagreement and portfolio choice. Journal of Finance.

Mian, A. R., Sufi, A., and Khoshkhou, N. (2021). Partisan bias, economic expectations, and household spending. The Review of Economics and Statistics.

MIT (2018). County presidential election returns 2000-2020. Harvard Dataverse. MIT Election Data and Science Lab. https://doi.org/10.7910/DVN/VOQCHQ (accessed July 16, 2019).

Nanda, R. and Rhodes-Kropf, M. (2013). Investment cycles and startup innovation. Journal of Financial Economics, 110(2):403-418.

Nanda, R. and Sørensen, J. B. (2010). Workplace peers and entrepreneurship. Management Science, 56(7):1116-1126.

Pástor, L. and Veronesi, P. (2020). Political cycles and stock returns. Journal of Political Economy, 128(11):4011-4045.

Pew (2018a). Commercial voter files and the study of us politics. Pew Research Center.

Pew (2018b). Wide gender gap, growing educational divide in voters' party identification. Pew Research Center.

Puri, M. and Robinson, D. T. (2013). The economic psychology of entrepreneurship and family business. Journal of Economics \&3 Management Strategy, 22(2):423-444.

Robb, A. M. and Robinson, D. T. (2014). The capital structure decisions of new firms. Review of Financial Studies, 27(1):153-179.

Robinson, J. A. and Verdier, T. (2013). The political economy of clientelism. The Scandinavian Journal of Economics, 115(2):260-291.

Schmalz, M. C., Sraer, D. A., and Thesmar, D. (2017). Housing collateral and entrepreneurship. Journal of Finance, 72(1):99-132. 
Schoar, A. (2010). The divide between subsistence and transformational entrepreneurship. Innovation Policy and the Economy, 10(1):57-81.

Spenkuch, J. L., Teso, E., and Xu, G. (2021). Ideology and performance in public organizations. NBER working paper.

Sterk, V., Sedláček, P., and Pugsley, B. (2021). The nature of firm growth. American Economic Review, 111(2):547-79.

Theil, H. (1954). Linear aggregation of economic relations.

Wilson, C. (2016). Why there are so many more names for baby girls. Time Magazine, $05 / 10 / 2016$.

Zandberg, J. (2021). Family comes first: Reproductive health and the gender gap in entrepreneurship. Journal of Financial Economics. 


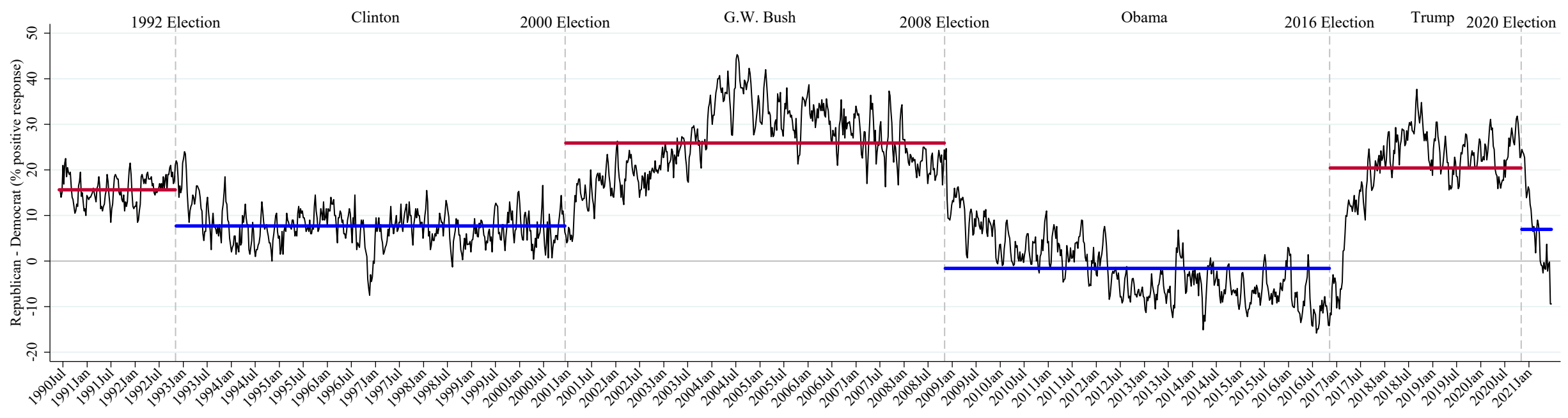

Figure 1. National optimism: the Bloomberg Consumer Comfort Index by party

Note: The black line plots the difference in The Bloomberg Consumer Comfort Index between Republicans and Democrats, and the horizontal lines plot the average of this difference between each party-switching presidential election. Survey respondents in the Bloomberg Consumer Comfort Index are asked to rate (i) the national economy, (ii) their personal finances, and (iii) the buying climate as "Excellent," "Good," "Not so Good," or "Poor." The Index is calculated as the four-week rolling average fraction of positive responses ("Good" or "Excellent") across the three questions. The sample is derived from 1,000 landline and cellular telephone interviews (national random sample), 250 per week, weighted to adjust for probabilities of selection by household size, telephone use, age, sex, race, education, metro status, and region. 


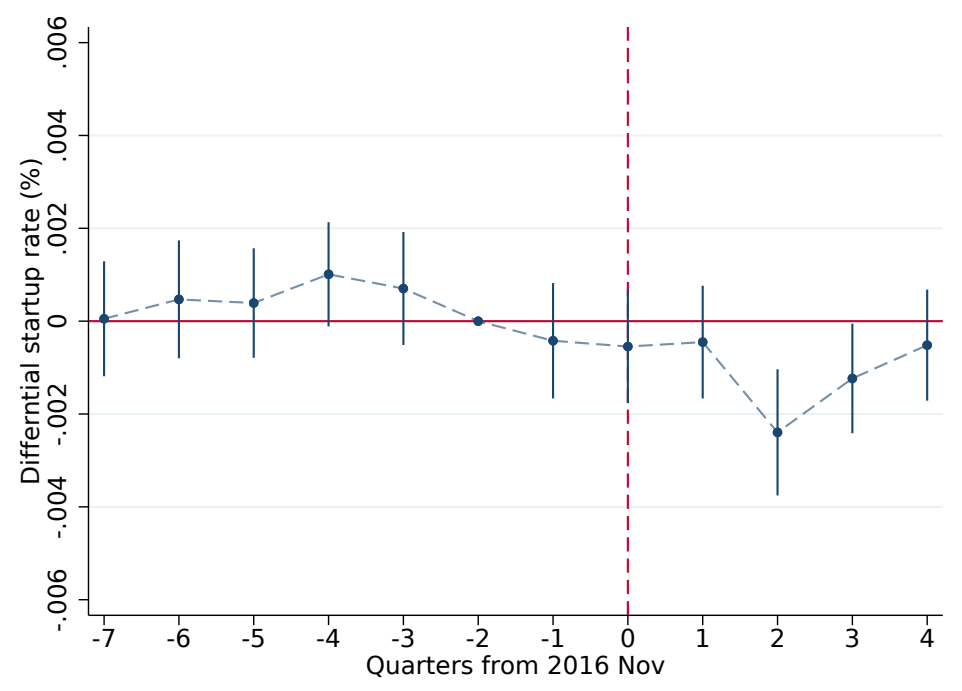

(a) 2016 election

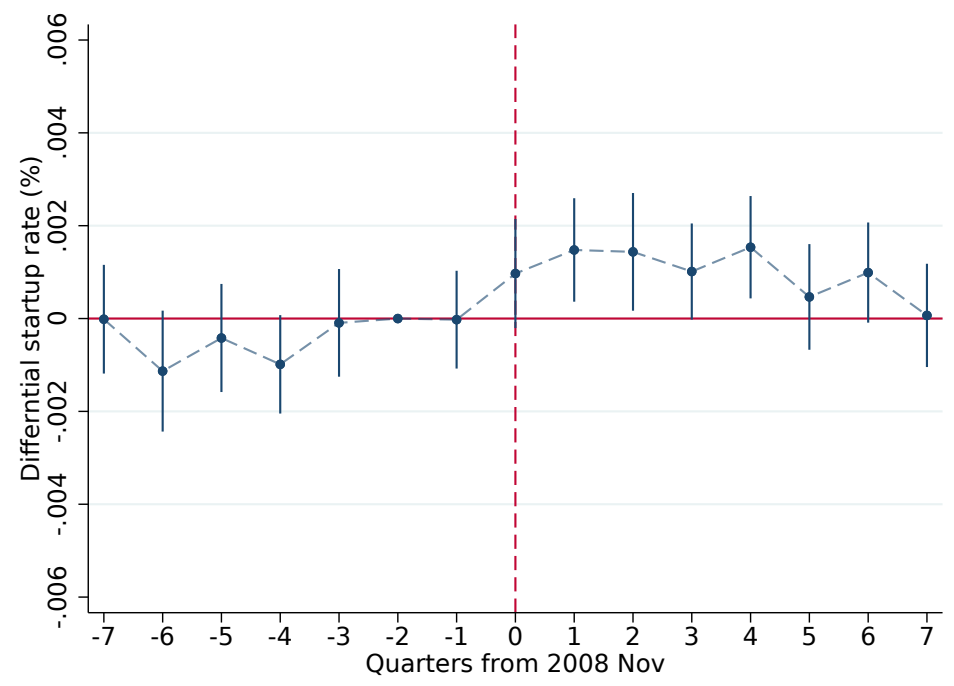

(b) 2008 election

Figure 2. Political mismatch and the probability of starting a business Democrat vs. Republican individuals

Note: This figure plots the coefficient on the Democrat indicator from equation 1 (at each event-time), capturing Democrats' excess probability of starting a business relative to Republican voters (omitted group). Units are in percentage points. Event time 0 denotes the month of a presidential election and the two subsequent months. For example, for the 2016 election event time 0 is November 2016 to January 2017. Event time -2 is the omitted period. All regressions control for county $\times$ event fixed effects and voter characteristics (gender, age groups, race). Regressions are run at the county-party-characteristic-month cell and are weighted by the number of observations in each cell. Standard errors are clustered by county. Regression coefficients are reported in Table A2. 


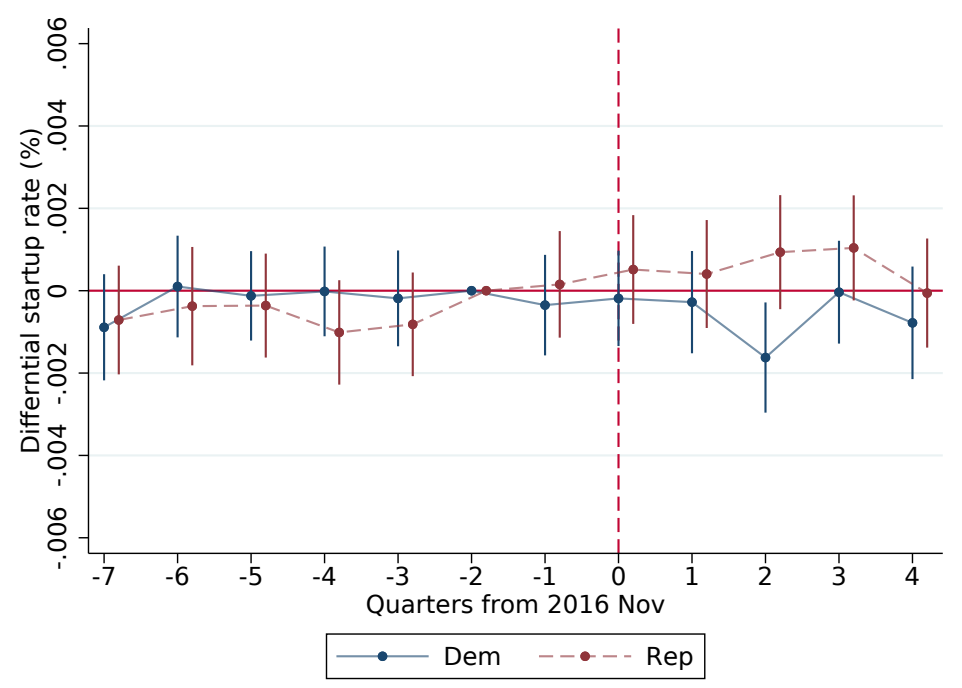

(a) 2016 election

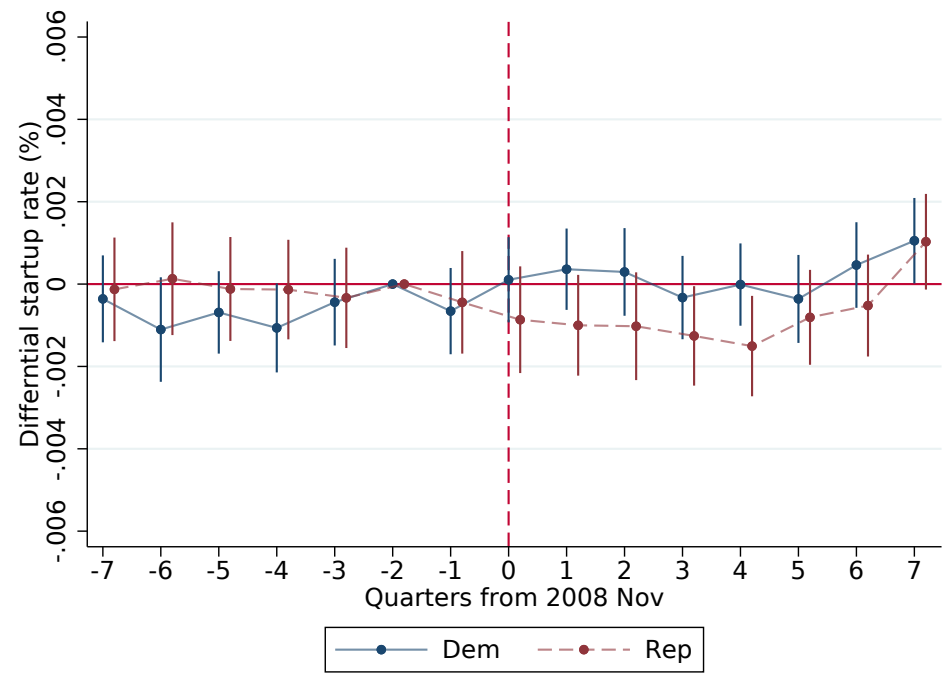

(b) 2008 election

Figure 3. Political mismatch and the probability of starting a business Democrat and Republican individuals vs. Independents

Note: This figure plots the coefficient on the Democrat indicator (at each event-time) from a modified version of equation 1, capturing Democrats' (blue solid line) and Republicans' (red dashed line) excess probability of starting a business relative to independent voters (omitted group). Units are in percentage points. Event time 0 denotes the month of a presidential election and the two subsequent months. For example, for the 2016 election event time 0 is November 2016 to January 2017. All regressions control for county $\times$ event time fixed effects and voter characteristics (gender, age groups, race). Regressions are run at the county-partycharacteristic-month cell and are weighted by the number of observations in each cell. Standard errors are clustered by county. Regression coefficients are reported in Appendix Table A11. 


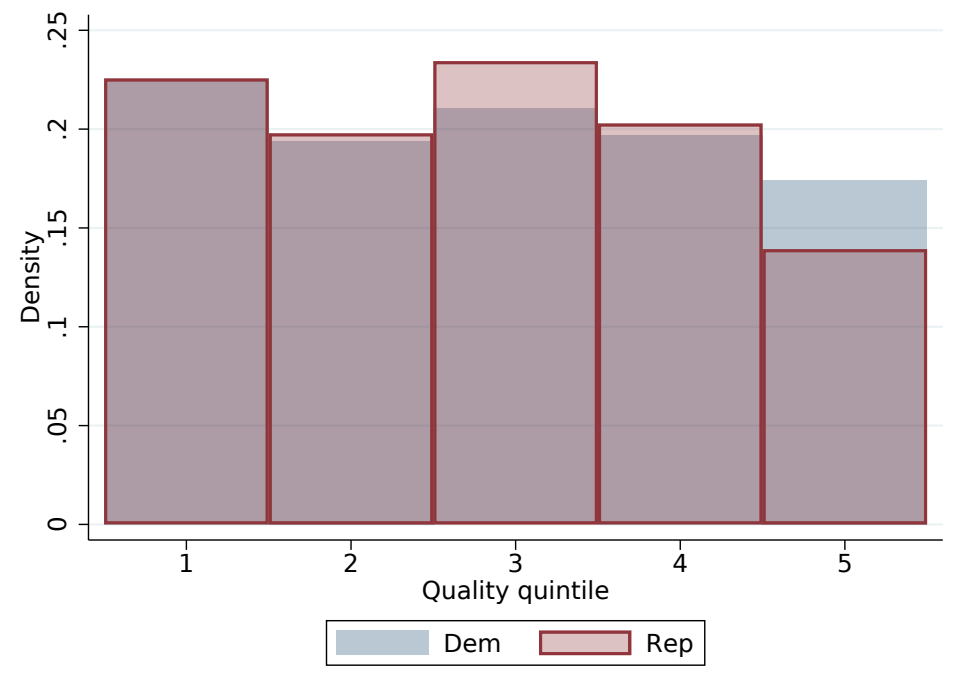

(a) By party

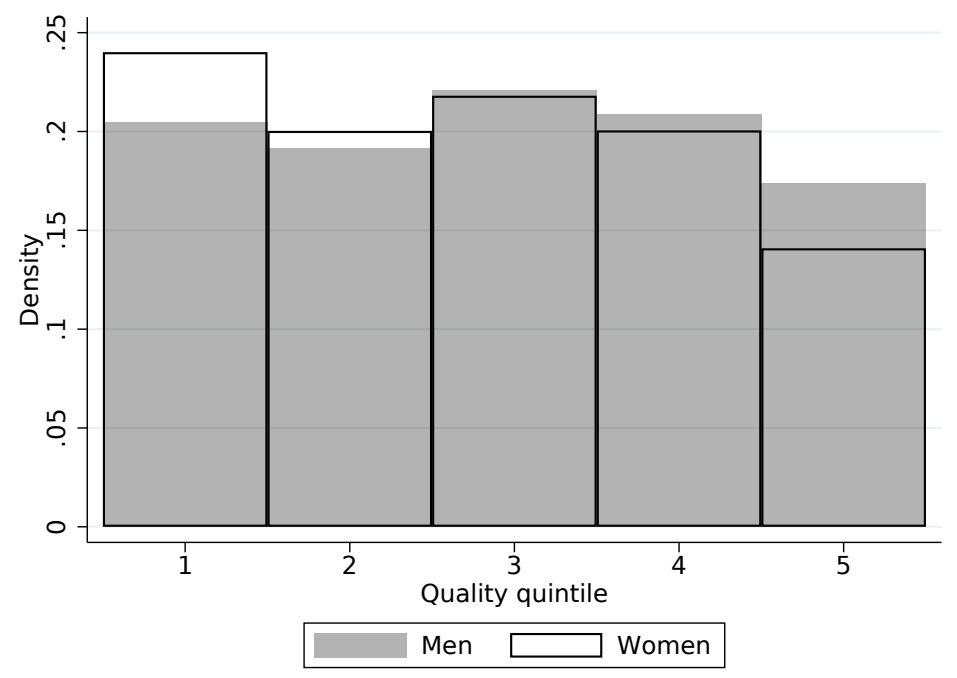

(b) By gender

Figure 4. Firm quality distribution by party and gender

Note: This figure plots the quintile of firm entrepreneurial quality (using the Guzman and Stern (2020) ex-ante quality measure) by founder party and gender. Quintile 1 corresponds to the lowest quality. 


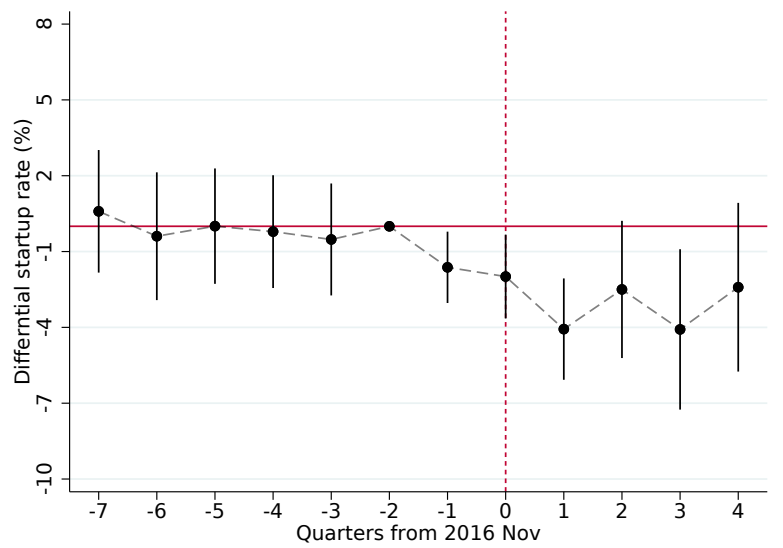

(a) 2016 election

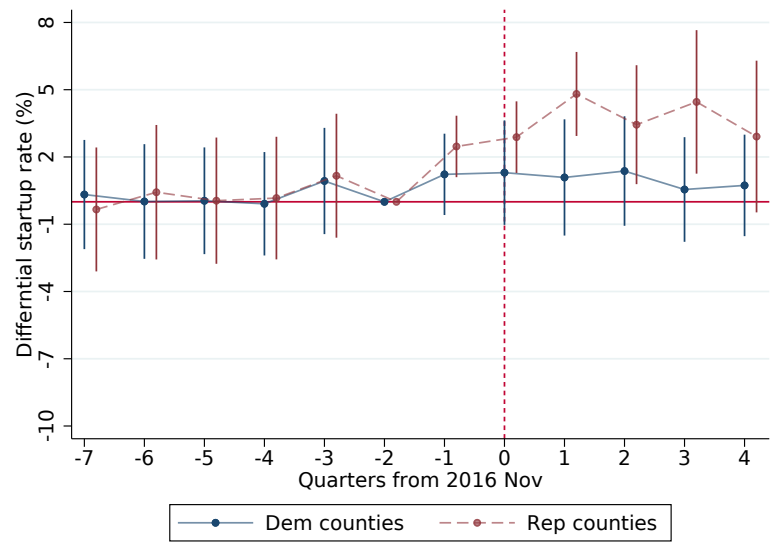

(c) 2016 election

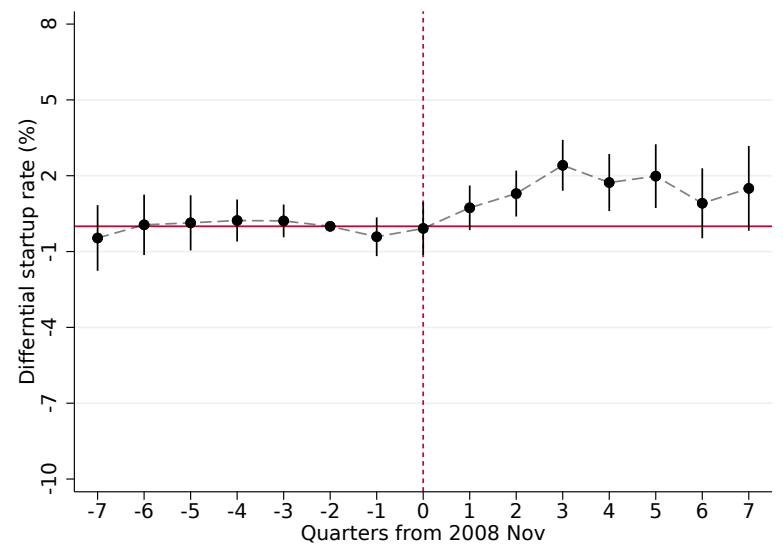

(b) 2008 election

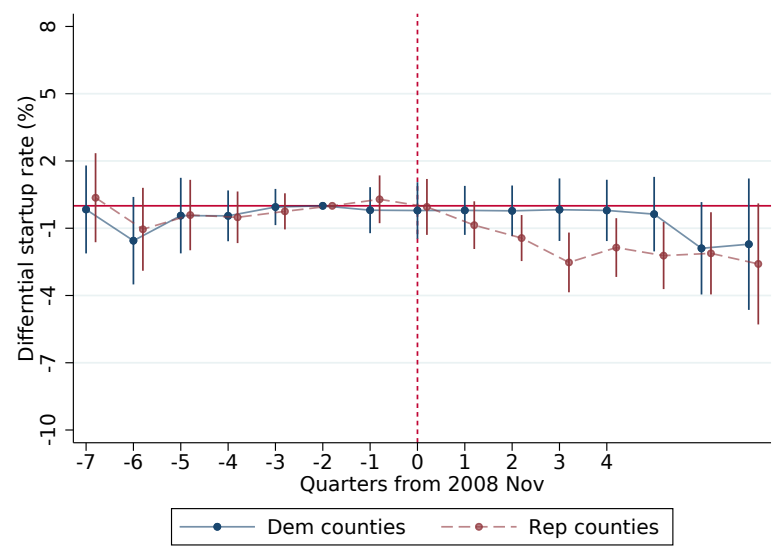

(d) 2008 election

Figure 5. Political mismatch and new firms: Democratic vs. Republican counties

Note: Panels (a) and (b) of this figure plot the coefficients on the Democratic-leaning indicator from equation 3, capturing these counties' startup rates relative to Republican-leaning counties (omitted group) in each time period. Panels (c) and (d) instead use "purple" counties as the omitted group. The dependent variable is the startup rate: the number of excess new firm registrations per 100,000 people 20 years old or older in a county. Purple counties are those reporting a victory margin of less than 10 percentage points in the preceding election. Event time 0 denotes the month of a presidential election and the two subsequent months. For example, for the 2016 election event time 0 is November 2016 to January 2017. Event time -2 is the omitted period. All regressions control for county fixed effects, event time fixed effects, and county economic conditions (monthly unemployment rate, annual per capita income, and annual employment share by NAICS-2 industries). Regressions are weighted by county population ages 20 and above. Standard errors are clustered by county. Regression coefficients are reported in Table A8. 


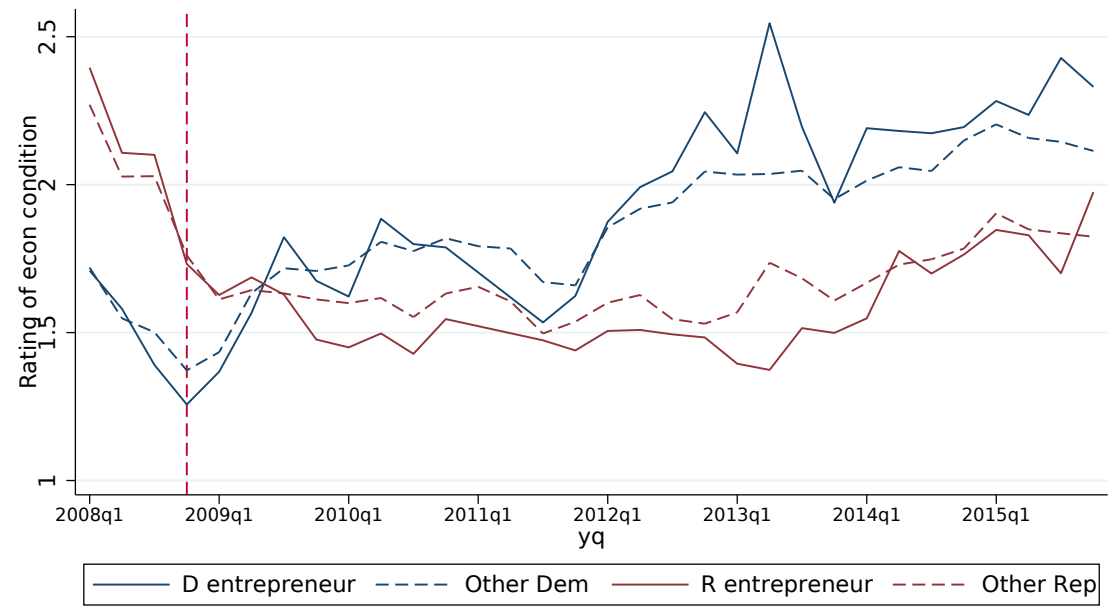

(a) Rating of economic conditions

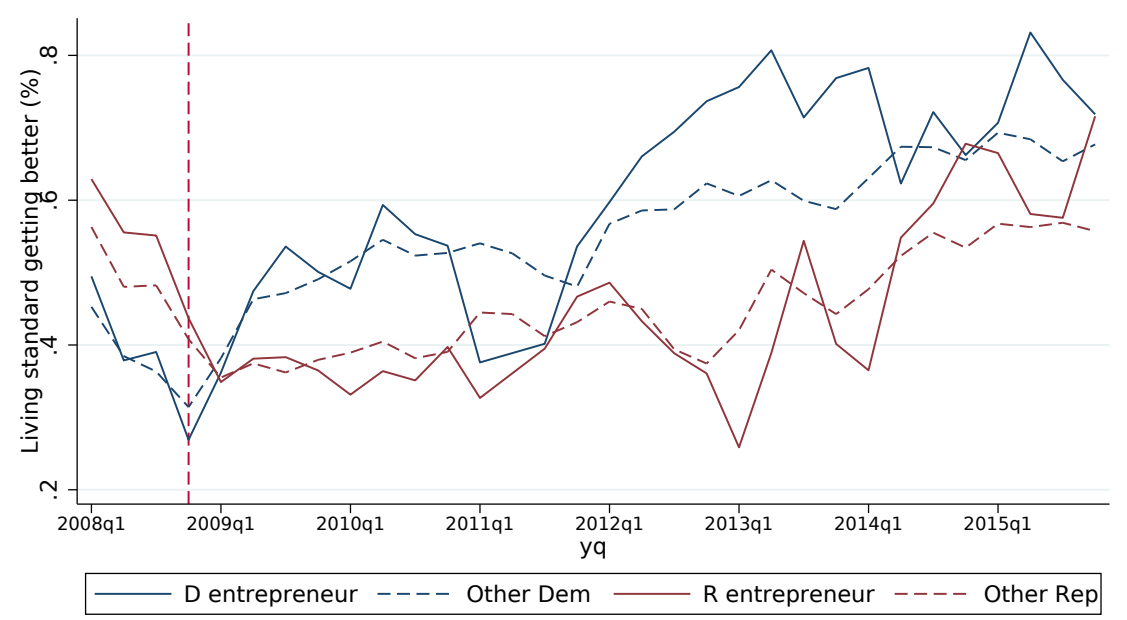

(b) Living standards are getting better

Figure 6. Optimism of business owners by party affiliation

Note: This figure plots quarterly average responses to the Gallup U.S. Daily Survey from 2008 through to the end of 2016. Section 5 describes the data. Panel (a) plots respondents' average rating ("Poor", "Only fair", "Good", and "Excellent", translated into a 1-4 range) to the question "How would you rate economic conditions in this country today?" and panel (b) the percentage of respondents choosing "Getting better" to the question "Right now, do you feel your standard of living is getting better or getting worse?" "Entrepreneurs" are self-identified business owners, while "other" refers to all other respondents. 


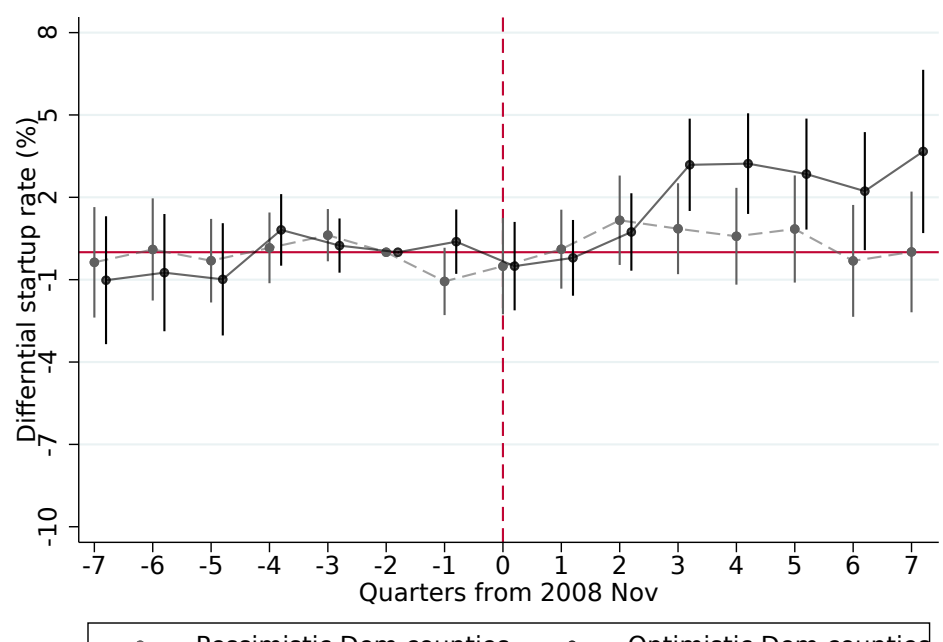

(a) Optimism about the economy

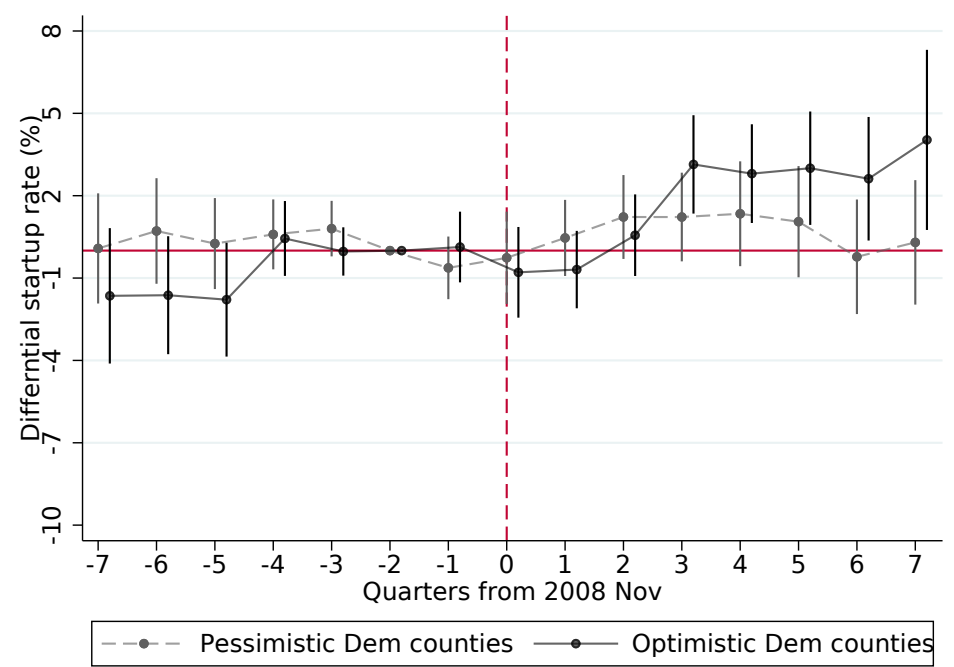

(b) Optimism about living standards

Figure 7. Political mismatch and new firms

More and less optimistic Democratic vs. Republican counties

Note: This figure plots coefficients from a county-level specification similar to equation 3 (and Figure 5) around the 2008 election. Democratic-leaning counties are split into optimistic and pessimistic groups; Republican-leaning counties are the omitted group. More (less) optimistic counties are those that have an above-median (below-median) change in optimism between 2008 and 2009. Panel (a) measures optimism using county average responses ("Poor", "Only fair", "Good", and "Excellent") to the question "How would you rate economic conditions in this country today?" and panel (b) the percentage of county respondents choosing "Getting better" to the question "Right now, do you feel your standard of living is getting better or getting worse?" in the Gallup U.S. Daily Survey. Event time 0 refers to November 2008 to January 2009. Event time -2 is the omitted period. All regressions control for county fixed effects, event time fixed effects, and county economic conditions (monthly unemployment rate, annual per capita income, and annual employment share for NAICS-2 industries). Regressions are weighted by county population ages 20 and above. Standard errors are clustered by county. Regression coefficients are reported in Table A9. 
Table 1

$\operatorname{Pr}($ start a business), $\operatorname{Pr}($ ever a founder) and summary statistics

\begin{tabular}{|c|c|c|c|c|c|c|c|c|c|}
\hline & \multicolumn{3}{|c|}{ Full sample } & \multicolumn{3}{|c|}{ Democrat } & \multicolumn{3}{|c|}{ Republican } \\
\hline & \multicolumn{2}{|c|}{ Probability (pp) } & \multirow[b]{2}{*}{ \%Sample } & \multicolumn{2}{|c|}{ Probability (pp) } & \multirow[b]{2}{*}{ \%Sample } & \multicolumn{2}{|c|}{ Probability (pp) } & \multirow[b]{2}{*}{ \%Sample } \\
\hline & Mean & $\mathrm{SD}$ & & Mean & $\mathrm{SD}$ & & Mean & $\mathrm{SD}$ & \\
\hline \multicolumn{10}{|l|}{ P(start business in a year): } \\
\hline All & 0.50 & 1.48 & 100.00 & 0.39 & 1.32 & 100.00 & 0.61 & 1.65 & 100.00 \\
\hline Male & 0.75 & 1.90 & 41.29 & 0.60 & 1.78 & 36.14 & 0.90 & 2.03 & 44.60 \\
\hline Female & 0.32 & 1.07 & 58.71 & 0.27 & 0.95 & 63.86 & 0.38 & 1.20 & 55.40 \\
\hline Educ. $\geq$ College & 0.69 & 1.64 & 47.13 & 0.55 & 1.51 & 45.60 & 0.78 & 1.70 & 49.79 \\
\hline Educ. others & 0.41 & 1.34 & 52.87 & 0.32 & 1.19 & 54.40 & 0.49 & 1.46 & 50.21 \\
\hline White & 0.47 & 1.18 & 75.69 & 0.37 & 1.10 & 62.17 & 0.58 & 1.26 & 90.92 \\
\hline Black & 0.35 & 1.36 & 11.13 & 0.34 & 1.08 & 20.04 & 0.48 & 3.43 & 1.52 \\
\hline Hispanic & 0.45 & 1.80 & 9.42 & 0.34 & 1.36 & 14.04 & 0.73 & 2.64 & 5.11 \\
\hline Asian & 0.90 & 3.06 & 3.76 & 0.72 & 2.71 & 3.75 & 1.00 & 3.74 & 2.45 \\
\hline Low income & 0.24 & 1.27 & 21.29 & 0.21 & 1.06 & 25.74 & 0.30 & 1.53 & 17.29 \\
\hline Middle income & 0.39 & 1.22 & 42.80 & 0.33 & 1.11 & 42.36 & 0.47 & 1.33 & 42.83 \\
\hline High income & 0.77 & 1.62 & 35.91 & 0.63 & 1.52 & 31.90 & 0.89 & 1.72 & 39.88 \\
\hline Age $18-29$ & 0.25 & 1.09 & 18.29 & 0.20 & 0.95 & 18.36 & 0.35 & 1.47 & 11.86 \\
\hline Age 30-39 & 0.65 & 1.77 & 18.30 & 0.53 & 1.60 & 17.49 & 0.81 & 2.09 & 15.33 \\
\hline Age $40-49$ & 0.66 & 1.67 & 21.69 & 0.54 & 1.53 & 20.45 & 0.77 & 1.78 & 23.41 \\
\hline Age 50-59 & 0.53 & 1.46 & 23.15 & 0.42 & 1.30 & 23.67 & 0.64 & 1.55 & 26.62 \\
\hline Age $60-70$ & 0.34 & 1.24 & 18.57 & 0.27 & 1.10 & 20.03 & 0.41 & 1.29 & 22.79 \\
\hline $\mathrm{N}$ voter $\times$ year & \multicolumn{3}{|c|}{$477,728,978$} & \multicolumn{3}{|c|}{$173,281,910$} & \multicolumn{3}{|c|}{$153,846,085$} \\
\hline N state & \multicolumn{3}{|c|}{33} & \multicolumn{3}{|c|}{33} & \multicolumn{3}{|c|}{33} \\
\hline \multicolumn{10}{|l|}{$P($ ever founder $):$} \\
\hline All & 4.59 & 20.92 & 100.00 & 3.69 & 18.85 & 100.00 & 5.53 & 22.86 & 100.00 \\
\hline Male & 6.57 & 24.78 & 41.32 & 5.39 & 22.59 & 36.15 & 7.72 & 26.69 & 44.62 \\
\hline Female & 3.19 & 17.57 & 58.68 & 2.72 & 16.28 & 63.85 & 3.77 & 19.04 & 55.38 \\
\hline Educ. $\geq$ College & 6.22 & 24.16 & 46.76 & 5.11 & 22.03 & 45.26 & 6.91 & 25.37 & 49.42 \\
\hline Educ. others & 3.94 & 19.46 & 53.24 & 3.14 & 17.45 & 54.74 & 4.66 & 21.07 & 50.58 \\
\hline White & 4.44 & 20.60 & 75.81 & 3.51 & 18.41 & 62.46 & 5.29 & 22.38 & 91.00 \\
\hline Black & 3.38 & 18.08 & 11.07 & 3.30 & 17.86 & 19.82 & 4.41 & 20.54 & 1.50 \\
\hline Hispanic & 4.10 & 19.82 & 9.40 & 3.17 & 17.52 & 13.99 & 6.28 & 24.26 & 5.08 \\
\hline Asian & 7.72 & 26.70 & 3.72 & 6.31 & 24.32 & 3.73 & 8.29 & 27.57 & 2.41 \\
\hline Low income & 2.25 & 14.83 & 22.76 & 1.93 & 13.76 & 27.23 & 2.69 & 16.18 & 19.28 \\
\hline Middle income & 3.87 & 19.29 & 42.32 & 3.27 & 17.79 & 41.74 & 4.59 & 20.93 & 42.19 \\
\hline High income & 7.01 & 25.54 & 34.92 & 5.85 & 23.46 & 31.02 & 7.97 & 27.08 & 38.53 \\
\hline Cohort $1990+$ & 1.19 & 10.82 & 7.88 & 0.95 & 9.72 & 7.44 & 1.54 & 12.31 & 4.79 \\
\hline Cohort 1980-89 & 3.93 & 19.44 & 15.26 & 3.16 & 17.50 & 15.45 & 5.08 & 21.96 & 10.06 \\
\hline Cohort 1970-79 & 6.53 & 24.71 & 17.09 & 5.44 & 22.67 & 16.17 & 7.81 & 26.84 & 14.98 \\
\hline Cohort 1960-69 & 6.30 & 24.30 & 20.53 & 5.15 & 22.10 & 19.22 & 7.34 & 26.07 & 22.94 \\
\hline Cohort 1950-59 & 4.95 & 21.70 & 20.97 & 3.98 & 19.56 & 22.05 & 5.96 & 23.68 & 23.90 \\
\hline Cohort 1940- & 2.43 & 15.40 & 18.27 & 1.95 & 13.82 & 19.67 & 2.86 & 16.66 & 23.32 \\
\hline $\mathrm{N}$ voter & \multicolumn{3}{|c|}{$40,420,508$} & \multicolumn{3}{|c|}{$14,696,895$} & \multicolumn{3}{|c|}{$13,083,051$} \\
\hline $\mathrm{N}$ state & \multicolumn{3}{|c|}{33} & \multicolumn{3}{|c|}{33} & & 33 & \\
\hline
\end{tabular}

Note: This table reports summary statistics (sample described in section 2) and two probabilities by population subset. $P$ (start business in a year) is the annual probability of starting a business among individuals aged 18 to 70 in our sample. $P$ (ever founder) is the probability of having started at least one business between 2005 and 2017 for the same sample. Units are in percentage points. Columns (1)-(3), (4)-(6) and (7)-(9) are calculated for samples of all individuals, Democrats, and Republicans, respectively (see section 2.2 for partisanship definition). \%Sample refers to the proportion of observations with a certain characteristic in the corresponding sample. Female is an indicator for being female; Educ. $\geq$ College (Educ. others) is an indicator for having a college degree or higher (no college degree); Low income, Middle income and High income are indicators for annual household incomes of $\$ 1,000-\$ 49,999, \$ 50,000-\$ 99,999$, and $\$ 100,000$ or above, respectively; Age $x x-y y$ is an indicator for being between $\mathrm{xx}$ and yy years old in a year; Cohort 19xx-yy is an indicator for being born between 19xx and 19yy. 
Table 2

Probability of starting a business by individual characteristics

\begin{tabular}{|c|c|c|c|c|c|c|c|c|}
\hline VARIABLES & $\begin{array}{c}(1) \\
\text { Party }\end{array}$ & $\begin{aligned} & (2) \\
+ \text { Age } & \end{aligned}$ & $\begin{array}{c}(3) \\
+ \text { Male }\end{array}$ & $\begin{array}{c}(4) \\
+ \text { Race } \\
\end{array}$ & $\begin{array}{c}(5) \\
+ \text { Educ. }\end{array}$ & $\begin{array}{c}(6) \\
+ \text { Income } \\
\end{array}$ & $\begin{array}{c}(7) \\
\text { Party } \times \text { Male }\end{array}$ & $\begin{array}{c}(8) \\
\text { Party } \times \text { Race }\end{array}$ \\
\hline Dem & $\begin{array}{c}-0.0815^{* * *} \\
(0.0093)\end{array}$ & $\begin{array}{c}-0.0771^{* * *} \\
(0.0089)\end{array}$ & $\begin{array}{c}-0.0421^{* * *} \\
(0.0076)\end{array}$ & $\begin{array}{c}-0.0161^{* * *} \\
(0.0055)\end{array}$ & $\begin{array}{c}-0.0242^{* * *} \\
(0.0057)\end{array}$ & $\begin{array}{c}-0.0220 * * * \\
(0.0054)\end{array}$ & $\begin{array}{c}0.0027 \\
(0.0064)\end{array}$ & $\begin{array}{c}-0.0466^{* * *} \\
(0.0161)\end{array}$ \\
\hline Rep & $\begin{array}{c}0.1621^{* * *} * \\
(0.0061)\end{array}$ & $\begin{array}{c}0.1539 * * * \\
(0.0059)\end{array}$ & $\begin{array}{c}0.1529^{* * *} \\
(0.0058)\end{array}$ & $\begin{array}{c}0.1460^{* * *} \\
(0.0054)\end{array}$ & $\begin{array}{c}0.1258^{* * *} * \\
(0.0052)\end{array}$ & $\begin{array}{c}0.1087^{* * *} * \\
(0.0050)\end{array}$ & $\begin{array}{c}0.0550^{* * *} \\
(0.0045)\end{array}$ & $\begin{array}{c}0.0930^{* * *} \\
(0.0139)\end{array}$ \\
\hline Age 18-29 & & $\begin{array}{c}-0.0605^{* * *} \\
(0.0061)\end{array}$ & $\begin{array}{c}-0.0609 * * * \\
(0.0061)\end{array}$ & $\begin{array}{c}-0.0449 * * * \\
(0.0055)\end{array}$ & $\begin{array}{l}-0.0018 \\
(0.0059)\end{array}$ & $\begin{array}{c}-0.0452^{* * *} \\
(0.0056)\end{array}$ & $\begin{array}{c}-0.0469 * * * \\
(0.0056)\end{array}$ & $\begin{array}{c}-0.0443^{* * *} \\
(0.0056)\end{array}$ \\
\hline Age $30-39$ & & $\begin{array}{c}0.3226^{* * *} \\
(0.0141)\end{array}$ & $\begin{array}{c}0.3302^{* * *} \\
(0.0145)\end{array}$ & $\begin{array}{c}0.3419^{* * *} \\
(0.0153)\end{array}$ & $\begin{array}{c}0.3611^{* * *} \\
(0.0166)\end{array}$ & $\begin{array}{c}0.3009 * * * \\
(0.0143)\end{array}$ & $\begin{array}{c}0.2999 * * * \\
(0.0143)\end{array}$ & $\begin{array}{c}0.3017^{* * *} \\
(0.0143)\end{array}$ \\
\hline Age 40-49 & & $\begin{array}{c}0.3296^{* * *} \\
(0.0137)\end{array}$ & $\begin{array}{c}0.3343^{* * *} \\
(0.0140)\end{array}$ & $\begin{array}{c}0.3415 * * * \\
(0.0145)\end{array}$ & $\begin{array}{c}0.3493^{* * *} \\
(0.0150)\end{array}$ & $\begin{array}{c}0.2954^{* * *} \\
(0.0128)\end{array}$ & $\begin{array}{c}0.2949^{* * *} \\
(0.0128)\end{array}$ & $\begin{array}{c}0.2959 * * * \\
(0.0129)\end{array}$ \\
\hline Age 50-59 & & $\begin{array}{c}0.2037^{* * *} \\
(0.0082)\end{array}$ & $\begin{array}{c}0.2044^{* * *} \\
(0.0083)\end{array}$ & $\begin{array}{c}0.2078^{* * *} \\
(0.0085)\end{array}$ & $\begin{array}{c}0.2095 * * * \\
(0.0086)\end{array}$ & $\begin{array}{c}0.1776^{* * *} \\
(0.0074)\end{array}$ & $\begin{array}{c}0.1773^{* * *} \\
(0.0074)\end{array}$ & $\begin{array}{c}0.1779 * * * \\
(0.0074)\end{array}$ \\
\hline Male & & & $\begin{array}{c}0.4330^{* * *} \\
(0.0208)\end{array}$ & $\begin{array}{c}0.4278^{* * *} \\
(0.0202)\end{array}$ & $\begin{array}{c}0.4256^{* * *} \\
(0.0200)\end{array}$ & $\begin{array}{c}0.4193^{* * *} \\
(0.0198)\end{array}$ & $\begin{array}{c}0.4048^{* * * *} \\
(0.0198)\end{array}$ & $\begin{array}{c}0.4193^{* * *} \\
(0.0199)\end{array}$ \\
\hline Black & & & & $\begin{array}{c}-0.0593^{*} \\
(0.0353)\end{array}$ & $\begin{array}{c}-0.0619^{*} \\
(0.0349)\end{array}$ & $\begin{array}{c}-0.0948^{* * *} \\
(0.0337)\end{array}$ & $\begin{array}{c}-0.0910^{* * *} \\
(0.0338)\end{array}$ & $\begin{array}{c}-0.1003 * * * \\
(0.0350)\end{array}$ \\
\hline Hispanic & & & & $\begin{array}{c}0.1508 * * * \\
(0.0203)\end{array}$ & $\begin{array}{c}0.1221^{* * *} \\
(0.0192)\end{array}$ & $\begin{array}{c}0.0582^{* * *} \\
(0.0178)\end{array}$ & $\begin{array}{c}0.0615^{* * * *} \\
(0.0178)\end{array}$ & $\begin{array}{c}0.0313^{* *} \\
(0.0153)\end{array}$ \\
\hline Asian & & & & $\begin{array}{c}0.4442^{* * *} \\
(0.0282)\end{array}$ & $\begin{array}{c}0.3984^{* * * *} \\
(0.0268)\end{array}$ & $\begin{array}{c}0.3213^{* * *} \\
(0.0250)\end{array}$ & $\begin{array}{c}0.3260^{* * *} \\
(0.0250)\end{array}$ & $\begin{array}{c}0.3540 * * * \\
(0.0256)\end{array}$ \\
\hline College+ & & & & & $\begin{array}{c}0.1939^{* * *} \\
(0.0106)\end{array}$ & $\begin{array}{c}0.1438^{* * *} \\
(0.0082)\end{array}$ & $\begin{array}{c}0.1432^{* * *} \\
(0.0082)\end{array}$ & $\begin{array}{c}0.1437^{* * *} * \\
(0.0082)\end{array}$ \\
\hline Mid income & & & & & & $\begin{array}{c}0.0847^{* * *} \\
(0.0042)\end{array}$ & $\begin{array}{c}0.0852^{* * *} \\
(0.0042)\end{array}$ & $\begin{array}{c}0.0846^{* * *} \\
(0.0042)\end{array}$ \\
\hline High income & & & & & & $\begin{array}{c}0.3504^{* * *} \\
(0.0163)\end{array}$ & $\begin{array}{c}0.3510^{* * *} \\
(0.0163)\end{array}$ & $\begin{array}{c}0.3501^{* * *} \\
(0.0163)\end{array}$ \\
\hline Dem $\times$ Male & & & & & & & $\begin{array}{c}-0.0718 * * * \\
(0.0084)\end{array}$ & \\
\hline Rep $\times$ Male & & & & & & & $\begin{array}{c}0.1191^{* * *} \\
(0.0103)\end{array}$ & \\
\hline Dem $\times$ Black & & & & & & & & $\begin{array}{l}-0.0099 \\
(0.0141)\end{array}$ \\
\hline Dem $\times$ Hispanic & & & & & & & & $\begin{array}{c}0.0448^{* * *} \\
(0.0154)\end{array}$ \\
\hline Dem $\times$ Asian & & & & & & & & $\begin{array}{c}-0.0705^{* * *} \\
(0.0241)\end{array}$ \\
\hline Rep $\times$ Black & & & & & & & & $\begin{array}{c}0.0496^{* *} \\
(0.0197)\end{array}$ \\
\hline Rep $\times$ Hispanic & & & & & & & & $\begin{array}{l}0.0241^{*} \\
(0.0139)\end{array}$ \\
\hline Rep $\times$ Asian & & & & & & & & $\begin{array}{c}-0.0579 * * \\
(0.0226)\end{array}$ \\
\hline Observations & $20,133,717$ & $20,133,717$ & $20,133,717$ & $20,133,717$ & $20,133,717$ & $20,133,717$ & $20,133,717$ & $20,133,717$ \\
\hline$R^{2}$ & 0.070 & 0.082 & 0.102 & 0.106 & 0.111 & 0.118 & 0.119 & 0.118 \\
\hline Outcome mean & .496 & .496 & .496 & .496 & .496 & .496 & .496 & .496 \\
\hline $\mathrm{N}$ obs & $477,728,978$ & $477,728,978$ & $477,728,978$ & $477,728,978$ & $477,728,978$ & $477,728,978$ & $477,728,978$ & $477,728,978$ \\
\hline $\mathrm{N}$ cluster (county) & 2,123 & 2,123 & 2,123 & 2,123 & 2,123 & 2,123 & 2,123 & 2,123 \\
\hline County $\times$ Year FE & $\mathrm{Y}$ & $\mathrm{Y}$ & $\mathrm{Y}$ & $\mathrm{Y}$ & $\mathrm{Y}$ & $\mathrm{Y}$ & $\mathrm{Y}$ & $\mathrm{Y}$ \\
\hline
\end{tabular}

Note: This table relates individuals' annual probability of starting a business to their personal characteristics. The sample is composed of Democrats, Republicans and Independents, and the outcome is the likelihood of starting a business in a year. Units are in percentage points. Dem is one for Democrats and zero for others; Rep is defined analogously (see section 2.2). Columns (4)-(8) additionally include indicators for missing race and/or missing income and the interactions between these indicators and Dem and Rep. Regressions are run at the county-party-characteristic-year cell level and are weighted by the number of observations in each cell. Standard errors are clustered by county. 
Table 3

Political mismatch and the probability of starting a business

\begin{tabular}{|c|c|c|c|c|c|c|c|c|}
\hline & (1) & $\begin{array}{c}(2) \\
\text { Cell-level }\end{array}$ & $\begin{array}{r}(3) \\
\text { gression }\end{array}$ & $(4)$ & \multicolumn{2}{|c|}{ Weighted person-level regression } & $\begin{array}{l}(7) \\
\text { level regression }\end{array}$ & $(8)$ \\
\hline & Regular voter & Active voter & Donor voter & FEC voter & Regular voter & Active voter & Donor voter & FEC voter \\
\hline Mismatch & $\begin{array}{c}-0.0165^{* * *} \\
(0.0017)\end{array}$ & $\begin{array}{c}-0.0119 * * * \\
(0.0019)\end{array}$ & $\begin{array}{c}-0.0138^{* * * *} \\
(0.0019)\end{array}$ & $\begin{array}{c}-0.0150^{* * *} \\
(0.0016)\end{array}$ & $\begin{array}{c}-0.0179^{* * *} \\
(0.0016)\end{array}$ & $\begin{array}{c}-0.0138^{* * *} \\
(0.0019)\end{array}$ & $\begin{array}{c}-0.0156^{* * *} \\
(0.0019)\end{array}$ & $\begin{array}{c}-0.0162^{* * *} \\
(0.0015)\end{array}$ \\
\hline Mismatch $\times$ Active & & $\begin{array}{c}-0.0097^{* * *} \\
(0.0020)\end{array}$ & $\begin{array}{c}-0.0067^{* * * *} \\
(0.0021)\end{array}$ & $\begin{array}{c}-0.0360 * * * \\
(0.0128)\end{array}$ & & $\begin{array}{c}-0.0080^{* * *} \\
(0.0019)\end{array}$ & $\begin{array}{c}-0.0058^{* * *} \\
(0.0021)\end{array}$ & $\begin{array}{c}-0.0330^{* * *} \\
(0.0122)\end{array}$ \\
\hline Dem & $\begin{array}{c}-0.1641 * * * \\
(0.0069)\end{array}$ & $\begin{array}{c}-0.1653^{* * * *} \\
(0.0085)\end{array}$ & $\begin{array}{c}-0.1644^{* * * *} \\
(0.0076)\end{array}$ & $\begin{array}{c}-0.1507^{* * *} \\
(0.0065)\end{array}$ & $\begin{array}{c}-0.1706^{* * *} \\
(0.0071)\end{array}$ & $\begin{array}{c}-0.1712^{* * *} \\
(0.0089)\end{array}$ & $\begin{array}{c}-0.1716^{* * *} \\
(0.0079)\end{array}$ & $\begin{array}{c}-0.1560 * * * \\
(0.0067)\end{array}$ \\
\hline Dem $\times$ Active & & $\begin{array}{l}-0.0049 \\
(0.0071)\end{array}$ & $\begin{array}{l}0.0093^{*} \\
(0.0052)\end{array}$ & $\begin{array}{c}-0.7080^{* * *} \\
(0.0371)\end{array}$ & & $\begin{array}{l}-0.0052 \\
(0.0072)\end{array}$ & $\begin{array}{l}0.0103^{*} \\
(0.0054)\end{array}$ & $\begin{array}{c}-0.7046^{* * *} \\
(0.0369)\end{array}$ \\
\hline Active & & $\begin{array}{c}0.1112^{* * *} \\
(0.0082)\end{array}$ & $\begin{array}{c}0.0507 * * * \\
(0.0045)\end{array}$ & $\begin{array}{c}1.6428 * * * \\
(0.0651)\end{array}$ & & $\begin{array}{c}0.1135^{* * *} \\
(0.0079)\end{array}$ & $\begin{array}{c}0.0481^{* * *} \\
(0.0044)\end{array}$ & $\begin{array}{c}1.6266^{* * * *} \\
(0.0623)\end{array}$ \\
\hline Male & $\begin{array}{c}0.4349^{* * *} \\
(0.0207)\end{array}$ & $\begin{array}{c}0.4363^{* * *} \\
(0.0208)\end{array}$ & $\begin{array}{c}0.4341^{* * *} \\
(0.0207)\end{array}$ & $\begin{array}{c}0.4208^{* * *} \\
(0.0202)\end{array}$ & $\begin{array}{c}0.4069^{* * *} \\
(0.0188)\end{array}$ & $\begin{array}{c}0.4083^{* * *} \\
(0.0189)\end{array}$ & $\begin{array}{c}0.4060^{* * *} \\
(0.0187)\end{array}$ & $\begin{array}{c}0.3936^{* * *} \\
(0.0183)\end{array}$ \\
\hline Age 18-29 & $\begin{array}{c}-0.0472^{* * *} \\
(0.0064)\end{array}$ & $\begin{array}{l}-0.0014 \\
(0.0071)\end{array}$ & $\begin{array}{c}-0.0354^{* * * *} \\
(0.0064)\end{array}$ & $\begin{array}{l}-0.0095^{*} \\
(0.0056)\end{array}$ & $\begin{array}{c}-0.0574^{* * * *} \\
(0.0066)\end{array}$ & $\begin{array}{l}-0.0102 \\
(0.0071)\end{array}$ & $\begin{array}{c}-0.0464^{* * *} \\
(0.0067)\end{array}$ & $\begin{array}{c}-0.0205^{* * *} \\
(0.0059)\end{array}$ \\
\hline Age $30-39$ & $\begin{array}{c}0.3403^{* * *} \\
(0.0158)\end{array}$ & $\begin{array}{c}0.3747^{* * *} \\
(0.0158)\end{array}$ & $\begin{array}{c}0.3497^{* * *} \\
(0.0163)\end{array}$ & $\begin{array}{c}0.3695^{* * *} \\
(0.0169)\end{array}$ & $\begin{array}{c}0.3463^{* * *} \\
(0.0163)\end{array}$ & $\begin{array}{c}0.3819^{* * *} \\
(0.0163)\end{array}$ & $\begin{array}{c}0.3555^{* * *} \\
(0.0167)\end{array}$ & $\begin{array}{c}0.3749^{* * * *} \\
(0.0173)\end{array}$ \\
\hline Age $40-49$ & $\begin{array}{c}0.3316^{* * *} \\
(0.0140)\end{array}$ & $\begin{array}{c}0.3551^{* * *} \\
(0.0140)\end{array}$ & $\begin{array}{c}0.3349 * * * \\
(0.0142)\end{array}$ & $\begin{array}{c}0.3519 * * * \\
(0.0149)\end{array}$ & $\begin{array}{c}0.3354^{* * *} \\
(0.0142)\end{array}$ & $\begin{array}{c}0.3598^{* * *} \\
(0.0142)\end{array}$ & $\begin{array}{c}0.3387^{* * *} \\
(0.0144)\end{array}$ & $\begin{array}{c}0.3554^{* * * *} \\
(0.0150)\end{array}$ \\
\hline Age $50-59$ & $\begin{array}{c}0.2041^{* * *} * \\
(0.0083)\end{array}$ & $\begin{array}{c}0.2156^{* * *} \\
(0.0083)\end{array}$ & $\begin{array}{c}0.2047^{* * *} * \\
(0.0083)\end{array}$ & $\begin{array}{c}0.2141^{* * *} \\
(0.0087)\end{array}$ & $\begin{array}{c}0.2046^{* * *} \\
(0.0083)\end{array}$ & $\begin{array}{c}0.2165^{* * *} \\
(0.0083)\end{array}$ & $\begin{array}{c}0.2052^{* * *} \\
(0.0083)\end{array}$ & $\begin{array}{c}0.2144^{* * * *} \\
(0.0086)\end{array}$ \\
\hline Asian & $\begin{array}{c}0.2508^{* * * *} \\
(0.0199)\end{array}$ & $\begin{array}{c}0.2616^{* * *} \\
(0.0207)\end{array}$ & $\begin{array}{c}0.2511^{* * * *} \\
(0.0199)\end{array}$ & $\begin{array}{c}0.2555^{* * * *} \\
(0.0196)\end{array}$ & $\begin{array}{c}0.2580^{* * * *} \\
(0.0198)\end{array}$ & $\begin{array}{c}0.2695^{* * *} \\
(0.0205)\end{array}$ & $\begin{array}{c}0.2583^{* * *} \\
(0.0197)\end{array}$ & $\begin{array}{c}0.2631^{* * *} \\
(0.0195)\end{array}$ \\
\hline Black & $\begin{array}{c}-0.1590^{* * *} \\
(0.0216)\end{array}$ & $\begin{array}{c}-0.1564^{* * *} \\
(0.0216)\end{array}$ & $\begin{array}{c}-0.1521^{* * *} \\
(0.0213)\end{array}$ & $\begin{array}{c}-0.1432^{* * *} \\
(0.0211)\end{array}$ & $\begin{array}{c}-0.1585^{* * *} \\
(0.0216)\end{array}$ & $\begin{array}{c}-0.1555^{* * *} \\
(0.0216)\end{array}$ & $\begin{array}{c}-0.1517^{* * *} \\
(0.0213)\end{array}$ & $\begin{array}{c}-0.1423^{* * *} \\
(0.0210)\end{array}$ \\
\hline Hispanic & $\begin{array}{c}-0.2151^{* * *} \\
(0.0264)\end{array}$ & $\begin{array}{c}-0.2015^{* * *} \\
(0.0269)\end{array}$ & $\begin{array}{c}-0.2060^{* * *} \\
(0.0263)\end{array}$ & $\begin{array}{c}-0.1976^{* * *} \\
(0.0255)\end{array}$ & $\begin{array}{c}-0.2120^{* * *} \\
(0.0254)\end{array}$ & $\begin{array}{c}-0.1978^{* * *} \\
(0.0259)\end{array}$ & $\begin{array}{c}-0.2030^{* * *} \\
(0.0253)\end{array}$ & $\begin{array}{c}-0.1938^{* * *} \\
(0.0245)\end{array}$ \\
\hline Mismatch as $\%$ mean & 3.33 & 2.4 & 2.8 & 3.03 & 3.68 & 2.85 & 3.21 & 3.33 \\
\hline Mismatch $\times$ Active as $\%$ mean & - & 1.94 & 1.35 & 7.26 & - & 1.64 & 1.19 & 6.78 \\
\hline$R^{2}$ & 0.105 & 0.070 & 0.071 & 0.082 & 0.005 & 0.005 & 0.005 & 0.005 \\
\hline Outcome mean & .495 & .495 & .495 & .495 & .485 & .486 & .485 & .485 \\
\hline $\mathrm{N}$ obs & $327,127,995$ & $326,699,233$ & $327,127,995$ & $327,127,995$ & $327,127,995$ & $326,699,233$ & $327,127,995$ & $327,127,995$ \\
\hline $\mathrm{N}$ cluster & 2,120 & 2,120 & 2,120 & 2,120 & 2,120 & 2,120 & 2,120 & 2,120 \\
\hline County $\times$ Year FE & Y & Y & $\mathrm{Y}$ & $\mathrm{Y}$ & $\mathrm{Y}$ & $\mathrm{Y}$ & $\mathrm{Y}$ & $\mathrm{Y}$ \\
\hline
\end{tabular}

Note: This table examines how individuals' annual probability of starting a business relates to being politically mismatched with the sitting president. The sample is composed of Democrats and Republicans and the outcome is the likelihood of starting a business in a year. Units are in percentage points. Mismatch is an indicator equal to one if an individual's political party is different from the party of the sitting president (it is one for Republicans in 2009-2016 and for Democrats in 2005-2008 and 2017). Dem is an indicator for Democratic individuals. Active is an indicator for politically active individuals, defined as (i) if they vote in an above-median share of their available even-year general and primary elections as of 2020 (columns 2 and 6); (ii) if the household has made at least one political donation by 2020 (columns 3 and 7 ); (iii) if the individual has made at least one FEC donation by 2020 (columns 4 and 8). Standard errors are clustered by county. "Cell-level regression" is equivalent to an unweighted individual-level regression: it is run at the county-party-characteristic-year cell level and weighted by number of observations in each cell. "Weighted person-level regression" is run at the individual level with each observation weighted so that the means of covariates in the re-weighted sample match those in the U.S. voter population. The matched characteristics are share of Democrats and, within each party, the shares of men, racial groups, and birth cohorts (see section 3.3.2 for details). Results are similar if we match sample averages to averages among all voters in sample counties. 
Table 4

Political mismatch and the probability of starting a business By gender, age, and household income

\begin{tabular}{|c|c|c|c|c|c|c|c|}
\hline & $\begin{array}{l}(1) \\
\text { Male }\end{array}$ & $\begin{array}{c}(2) \\
\text { Female }\end{array}$ & $\begin{array}{c}(3) \\
\text { Age 18-29 } \\
\end{array}$ & $\begin{array}{c}(4) \\
\text { Age } 30-49 \\
\end{array}$ & $\begin{array}{c}(5) \\
\text { Age } 50-70 \\
\end{array}$ & $\begin{array}{c}(6) \\
\text { High income }\end{array}$ & $\begin{array}{c}(7) \\
\text { Low income }\end{array}$ \\
\hline Mismatch & $\begin{array}{c}-0.0283^{* * *} \\
(0.0025)\end{array}$ & $\begin{array}{c}-0.0049^{* * *} \\
(0.0013)\end{array}$ & $\begin{array}{c}-0.0188^{* * *} \\
(0.0021)\end{array}$ & $\begin{array}{c}-0.0221^{* * *} \\
(0.0025)\end{array}$ & $\begin{array}{c}-0.0090^{* * *} \\
(0.0016)\end{array}$ & $\begin{array}{c}-0.0223^{* * *} \\
(0.0029)\end{array}$ & $\begin{array}{c}-0.0145^{* * *} \\
(0.0012)\end{array}$ \\
\hline Dem & $\begin{array}{c}-0.2737^{* * *} \\
(0.0121)\end{array}$ & $\begin{array}{c}-0.0896^{* * *} \\
(0.0047)\end{array}$ & $\begin{array}{c}-0.1085^{* * *} \\
(0.0061)\end{array}$ & $\begin{array}{c}-0.2040^{* * *} \\
(0.0092)\end{array}$ & $\begin{array}{c}-0.1523^{* * *} \\
(0.0061)\end{array}$ & $\begin{array}{c}-0.1755^{* * * *} \\
(0.0092)\end{array}$ & $\begin{array}{c}-0.1124^{* * *} \\
(0.0046)\end{array}$ \\
\hline Male & & & $\begin{array}{c}0.2475^{* * *} \\
(0.0136)\end{array}$ & $\begin{array}{c}0.5636^{* * * *} \\
(0.0272)\end{array}$ & $\begin{array}{c}0.3922^{* * *} \\
(0.0184)\end{array}$ & $\begin{array}{c}0.6883^{* * *} \\
(0.0388)\end{array}$ & $\begin{array}{c}0.2866^{* * *} \\
(0.0113)\end{array}$ \\
\hline Age $18-29$ & $\begin{array}{c}-0.0972^{* * * *} \\
(0.0107)\end{array}$ & $\begin{array}{c}-0.0200^{* * *} \\
(0.0045)\end{array}$ & & & & $\begin{array}{c}-0.1463^{* * *} \\
(0.0125)\end{array}$ & $\begin{array}{c}-0.0217^{* * *} \\
(0.0039)\end{array}$ \\
\hline Age 30-39 & $\begin{array}{c}0.4897^{* * *} \\
(0.0225)\end{array}$ & $\begin{array}{c}0.2422^{* * *} \\
(0.0119)\end{array}$ & & $\begin{array}{c}0.0126^{* * *} \\
(0.0039)\end{array}$ & & $\begin{array}{c}0.4072^{* * * *} \\
(0.0216)\end{array}$ & $\begin{array}{c}0.2345^{* * *} \\
(0.0117)\end{array}$ \\
\hline Age $40-49$ & $\begin{array}{c}0.4567^{* * *} \\
(0.0203)\end{array}$ & $\begin{array}{c}0.2467^{* * *} * \\
(0.0104)\end{array}$ & & & & $\begin{array}{c}0.4156^{* * *} \\
(0.0199)\end{array}$ & $\begin{array}{c}0.2153^{* * *} \\
(0.0089)\end{array}$ \\
\hline Age 50-59 & $\begin{array}{c}0.2679^{* * *} \\
(0.0117)\end{array}$ & $\begin{array}{c}0.1597^{* * *} \\
(0.0063)\end{array}$ & & & $\begin{array}{c}0.1997^{* * *} \\
(0.0081)\end{array}$ & $\begin{array}{c}0.2704^{* * *} \\
(0.0131)\end{array}$ & $\begin{array}{c}0.1401^{* * *} \\
(0.0053)\end{array}$ \\
\hline Asian & $\begin{array}{c}0.3752^{* * *} \\
(0.0364)\end{array}$ & $\begin{array}{c}0.1529 * * * \\
(0.0119)\end{array}$ & $\begin{array}{c}0.1351^{* * *} \\
(0.0144)\end{array}$ & $\begin{array}{c}0.3758^{* * *} \\
(0.0299)\end{array}$ & $\begin{array}{c}0.1642^{* * *} \\
(0.0140)\end{array}$ & $\begin{array}{c}0.2979^{* * *} \\
(0.0301)\end{array}$ & $\begin{array}{c}0.1308^{* * *} \\
(0.0107)\end{array}$ \\
\hline Black & $\begin{array}{c}-0.2931^{* * *} \\
(0.0392)\end{array}$ & $\begin{array}{c}-0.0894^{* * *} \\
(0.0124)\end{array}$ & $\begin{array}{c}-0.0976^{* * *} \\
(0.0154)\end{array}$ & $\begin{array}{c}-0.2128^{* * *} \\
(0.0275)\end{array}$ & $\begin{array}{c}-0.1342^{* * *} \\
(0.0191)\end{array}$ & $\begin{array}{c}-0.1017^{* * *} \\
(0.0259)\end{array}$ & $\begin{array}{c}-0.0860^{* * *} \\
(0.0135)\end{array}$ \\
\hline Hispanic & $\begin{array}{c}-0.3567^{* * *} \\
(0.0480)\end{array}$ & $\begin{array}{c}-0.1250^{* * *} \\
(0.0164)\end{array}$ & $\begin{array}{c}-0.0913^{* * *} \\
(0.0202)\end{array}$ & $\begin{array}{c}-0.2739^{* * *} \\
(0.0339)\end{array}$ & $\begin{array}{c}-0.2111^{* * *} * \\
(0.0233)\end{array}$ & $\begin{array}{c}-0.2320^{* * *} \\
(0.0303)\end{array}$ & $\begin{array}{c}-0.1322^{* * *} \\
(0.0177)\end{array}$ \\
\hline Mismatch as \%mean & 3.75 & 1.54 & 7.4 & 3.39 & 2.04 & 2.91 & 4.21 \\
\hline$R^{2}$ & 0.117 & 0.077 & 0.065 & 0.122 & 0.098 & 0.185 & 0.073 \\
\hline Outcome mean & .756 & .32 & .254 & .653 & .444 & .767 & .345 \\
\hline $\mathrm{N}$ obs & $131,246,407$ & $195,881,588$ & $50,051,494$ & $125,332,715$ & $151,743,786$ & $114,056,924$ & $205,764,381$ \\
\hline $\mathrm{N}$ cluster (county) & 2,115 & 2,120 & 2,114 & 2,116 & 2,116 & 2,108 & 2,111 \\
\hline County $\times$ Year FE & $\mathrm{Y}$ & $\mathrm{Y}$ & $\mathrm{Y}$ & $\mathrm{Y}$ & $\mathrm{Y}$ & $\mathrm{Y}$ & $\mathrm{Y}$ \\
\hline
\end{tabular}

Note: This table examines how individuals' annual probability of starting a business relates to being politically mismatched with the sitting president in different subsamples. Columns (1) through (7) re-estimate Table 3 panel A column (1) for men, women, voters ages $18-29$, voters ages $30-49$, voters ages $50-70$, voters whose annual household income is above $\$ 100,000$, and voters whose annual household income is below $\$ 100,000$, respectively. All specifications and variable definitions mirror those in Table 3 panel A column (1). 
Table 5

Political mismatch and the probability of starting different types of firm

\begin{tabular}{|c|c|c|c|c|c|c|c|c|c|c|}
\hline & $\begin{array}{c}(1) \\
\text { LLC }\end{array}$ & $\begin{array}{c}(2) \\
\text { Corporation }\end{array}$ & $\begin{array}{c}(3) \\
\text { VC backed }\end{array}$ & $\begin{array}{c}(4) \\
\text { Patent firm }\end{array}$ & $\begin{array}{c}(5) \\
\mathrm{Q}: \text { top } 5 \%\end{array}$ & $\begin{array}{c}(6) \\
\mathrm{Q}: 80-100 \%\end{array}$ & $\begin{array}{c}(7) \\
\mathrm{Q}: 60-80 \%\end{array}$ & $\begin{array}{c}(8) \\
Q: 40-60 \%\end{array}$ & $\begin{array}{c}(9) \\
\mathrm{Q}: 20-40 \%\end{array}$ & $\begin{array}{c}(10) \\
\text { Q: } 0-20 \%\end{array}$ \\
\hline Mismatch & $\begin{array}{c}-0.003^{*} \\
(0.001)\end{array}$ & $\begin{array}{c}-0.014^{* * *} \\
(0.001)\end{array}$ & $\begin{array}{l}-0.0000 \\
(0.0000)\end{array}$ & $\begin{array}{l}-0.0001 \\
(0.0001)\end{array}$ & $\begin{array}{c}-0.001^{* * *} \\
(0.000)\end{array}$ & $\begin{array}{c}-0.004^{* * *} \\
(0.001)\end{array}$ & $\begin{array}{c}-0.003^{* * *} \\
(0.001)\end{array}$ & $\begin{array}{c}-0.002^{* * *} \\
(0.001)\end{array}$ & $\begin{array}{c}-0.001^{* *} \\
(0.000)\end{array}$ & $\begin{array}{c}-0.003^{* * *} \\
(0.001)\end{array}$ \\
\hline Dem & $\begin{array}{c}-0.124^{* * *} \\
(0.006)\end{array}$ & $\begin{array}{c}-0.042^{* * *} \\
(0.003)\end{array}$ & $\begin{array}{l}-0.0000 \\
(0.0000)\end{array}$ & $\begin{array}{c}-0.0006^{* * *} \\
(0.0001)\end{array}$ & $\begin{array}{c}-0.004^{* * *} \\
(0.001)\end{array}$ & $\begin{array}{c}-0.022^{* * *} \\
(0.002)\end{array}$ & $\begin{array}{c}-0.033^{* * *} \\
(0.002)\end{array}$ & $\begin{array}{c}-0.035^{* * *} \\
(0.002)\end{array}$ & $\begin{array}{c}-0.030 * * * \\
(0.002)\end{array}$ & $\begin{array}{c}-0.031^{* * *} \\
(0.003)\end{array}$ \\
\hline Male & $\begin{array}{c}0.308^{* * *} \\
(0.014)\end{array}$ & $\begin{array}{c}0.130^{* * *} \\
(0.010)\end{array}$ & $\begin{array}{c}0.0003^{* * *} \\
(0.0001)\end{array}$ & $\begin{array}{c}0.0026^{* * *} \\
(0.0002)\end{array}$ & $\begin{array}{c}0.020^{* * *} \\
(0.005)\end{array}$ & $\begin{array}{c}0.078^{* * *} \\
(0.011)\end{array}$ & $\begin{array}{c}0.087^{* * *} \\
(0.006)\end{array}$ & $\begin{array}{c}0.093^{* * *} \\
(0.007)\end{array}$ & $\begin{array}{c}0.080^{* * *} \\
(0.005)\end{array}$ & $\begin{array}{c}0.080^{* * *} \\
(0.005)\end{array}$ \\
\hline Age $18-29$ & $\begin{array}{c}-0.024^{* * *} \\
(0.005)\end{array}$ & $\begin{array}{c}-0.023^{* * *} \\
(0.002)\end{array}$ & $\begin{array}{c}-0.0000^{*} \\
(0.0000)\end{array}$ & $\begin{array}{c}-0.0006^{* * *} \\
(0.0001)\end{array}$ & $\begin{array}{c}-0.003^{* * *} \\
(0.000)\end{array}$ & $\begin{array}{c}-0.011^{* * *} \\
(0.002)\end{array}$ & $\begin{array}{c}-0.012^{* * *} \\
(0.002)\end{array}$ & $\begin{array}{c}-0.016^{* * *} \\
(0.002)\end{array}$ & $\begin{array}{c}-0.004^{* * *} \\
(0.001)\end{array}$ & $\begin{array}{c}0.004^{* *} \\
(0.002)\end{array}$ \\
\hline Age $30-39$ & $\begin{array}{c}0.249^{* * *} \\
(0.011)\end{array}$ & $\begin{array}{c}0.094^{* * *} \\
(0.009)\end{array}$ & $\begin{array}{c}0.0002^{* * *} \\
(0.0001)\end{array}$ & $\begin{array}{c}0.0007^{* * *} \\
(0.0001)\end{array}$ & $\begin{array}{c}0.011^{* * *} \\
(0.003)\end{array}$ & $\begin{array}{c}0.049^{* * *} \\
(0.007)\end{array}$ & $\begin{array}{c}0.059^{* * *} \\
(0.004)\end{array}$ & $\begin{array}{c}0.066^{* * *} \\
(0.005)\end{array}$ & $\begin{array}{c}0.064^{* * *} \\
(0.004)\end{array}$ & $\begin{array}{c}0.080^{* * *} \\
(0.006)\end{array}$ \\
\hline Age $40-49$ & $\begin{array}{c}0.237^{* * *} \\
(0.010)\end{array}$ & $\begin{array}{c}0.097^{* * *} * \\
(0.007)\end{array}$ & $\begin{array}{c}0.0002^{* * *} \\
(0.0000)\end{array}$ & $\begin{array}{c}0.0013^{* * *} \\
(0.0001)\end{array}$ & $\begin{array}{c}0.013^{* * *} \\
(0.003)\end{array}$ & $\begin{array}{c}0.054^{* * *} \\
(0.007)\end{array}$ & $\begin{array}{c}0.062^{* * *} \\
(0.004)\end{array}$ & $\begin{array}{c}0.066^{* * *} \\
(0.005)\end{array}$ & $\begin{array}{c}0.062^{* * *} \\
(0.003)\end{array}$ & $\begin{array}{c}0.068^{* * *} \\
(0.005)\end{array}$ \\
\hline Age 50-59 & $\begin{array}{c}0.150^{* * *} \\
(0.006)\end{array}$ & $\begin{array}{c}0.055^{* * *} \\
(0.004)\end{array}$ & $\begin{array}{c}0.0001^{* * *} \\
(0.0000)\end{array}$ & $\begin{array}{c}0.0007^{* * *} \\
(0.0001)\end{array}$ & $\begin{array}{c}0.007^{* * * *} \\
(0.001)\end{array}$ & $\begin{array}{c}0.030^{* * * *} \\
(0.004)\end{array}$ & $\begin{array}{c}0.037^{* * *} \\
(0.002)\end{array}$ & $\begin{array}{c}0.042^{* * *} \\
(0.003)\end{array}$ & $\begin{array}{c}0.040^{* * *} \\
(0.002)\end{array}$ & $\begin{array}{c}0.045^{* * *} \\
(0.003)\end{array}$ \\
\hline Black & $\begin{array}{c}-0.141^{* * *} \\
(0.015)\end{array}$ & $\begin{array}{c}-0.018^{*} \\
(0.009)\end{array}$ & $\begin{array}{c}-0.0001^{* * *} \\
(0.0000)\end{array}$ & $\begin{array}{c}-0.0008 * * * \\
(0.0001)\end{array}$ & $\begin{array}{l}-0.003^{*} \\
(0.002)\end{array}$ & $\begin{array}{c}-0.017^{* * *} \\
(0.006)\end{array}$ & $\begin{array}{c}-0.017^{* * *} \\
(0.005)\end{array}$ & $\begin{array}{c}-0.040 * * * \\
(0.008)\end{array}$ & $\begin{array}{c}-0.032^{* * *} \\
(0.005)\end{array}$ & $\begin{array}{c}-0.028^{* * *} \\
(0.005)\end{array}$ \\
\hline Hispanic & $\begin{array}{c}-0.186^{* * *} \\
(0.014)\end{array}$ & $\begin{array}{c}-0.028^{*} \\
(0.016)\end{array}$ & $\begin{array}{c}-0.0002^{* * *} \\
(0.0000)\end{array}$ & $\begin{array}{c}-0.0015^{* * *} \\
(0.0002)\end{array}$ & $\begin{array}{c}-0.018^{* * *} \\
(0.006)\end{array}$ & $\begin{array}{c}-0.048^{* * *} \\
(0.018)\end{array}$ & $\begin{array}{c}-0.050^{* * *} \\
(0.009)\end{array}$ & $\begin{array}{c}-0.051^{* * *} \\
(0.004)\end{array}$ & $\begin{array}{c}-0.020^{* * *} \\
(0.003)\end{array}$ & $\begin{array}{c}-0.038^{* * *} \\
(0.006)\end{array}$ \\
\hline Mismatch as $\%$ mean & .74 & 10.71 & 15.89 & 4.73 & 4.77 & 6.36 & 3.04 & 2.01 & 1.28 & 2.48 \\
\hline$R^{2}$ & 0.093 & 0.051 & 0.004 & 0.004 & 0.048 & 0.063 & 0.052 & 0.057 & 0.034 & 0.055 \\
\hline Outcome mean & .363 & .134 & 0 & .0015 & .014 & .069 & .09 & .101 & .089 & .101 \\
\hline $\mathrm{N}$ obs & $327,126,172$ & $327,127,995$ & $327,127,995$ & $327,127,995$ & $326,925,933$ & $326,925,933$ & $326,925,933$ & $326,925,933$ & $326,925,933$ & $326,925,933$ \\
\hline $\mathrm{N}$ cluster (county) & 2,120 & 2,120 & 2,120 & 2,120 & 2,120 & 2,120 & 2,120 & 2,120 & 2,120 & 2,120 \\
\hline County $\times$ Year FE & $\mathrm{Y}$ & $\mathrm{Y}$ & $\mathrm{Y}$ & $\mathrm{Y}$ & $\mathrm{Y}$ & $\mathrm{Y}$ & $\mathrm{Y}$ & $\mathrm{Y}$ & $\mathrm{Y}$ & $\mathrm{Y}$ \\
\hline
\end{tabular}

Note: This table examines how individuals' annual probability of starting different types of firms relates to being politically mismatched with the sitting president. It is identical to the specification in Table 3 panel A column (1) except that the dependent variable is the annual probability of starting a specific type of firm, which differs by column. Units are in percentage points. "LLC" refers to limited liability companies registered under the jurisdiction of their headquarters (or local) state. "Corporation" refers to corporations registered under local state jurisdiction. "VC backed" refers to firms that ever receive venture capital investment. "Patent firm" refers to firms that have ever filed for patents according to the USPTO data. "Q: xx" refers to businesses who score in a certain percentile range of entrepreneurial quality (Guzman and Stern, 2020). 
Table 6

Political mismatch and employer firms: County-level business dynamics

\begin{tabular}{|c|c|c|c|c|c|c|c|}
\hline & (1) & (2) & (3) & (4) & (5) & (6) & $\begin{array}{l}(7) \\
\text { firm }\end{array}$ \\
\hline & \multicolumn{2}{|c|}{ New firm } & \multicolumn{4}{|c|}{ Existing firm } & All firm \\
\hline & Firm entry & Job creation rate & Estab. entry & Estab. exit & Firm death & Net job creation rate & Net job creation rate \\
\hline Mismatch & $\begin{array}{c}-5.460 * * * \\
(0.856)\end{array}$ & $\begin{array}{c}-0.003 \\
(0.002)\end{array}$ & $\begin{array}{c}-0.284^{* * *} \\
(0.088)\end{array}$ & $\begin{array}{c}0.762^{* * *} \\
(0.172)\end{array}$ & $\begin{array}{c}0.655^{* * *} \\
(0.132)\end{array}$ & $\begin{array}{c}-0.327^{* * *} \\
(0.064)\end{array}$ & $\begin{array}{c}-0.324^{* * *} \\
(0.063)\end{array}$ \\
\hline Unemp $(\%)$ & $\begin{array}{c}-2.503^{* * *} \\
(0.341)\end{array}$ & $\begin{array}{c}-0.000 \\
(0.000)\end{array}$ & $\begin{array}{c}0.051 \\
(0.052)\end{array}$ & $\begin{array}{c}1.980^{* * *} \\
(0.169)\end{array}$ & $\begin{array}{c}1.358^{* * *} \\
(0.135)\end{array}$ & $\begin{array}{c}-0.685^{* * *} \\
(0.067)\end{array}$ & $\begin{array}{c}-0.679^{* * *} \\
(0.066)\end{array}$ \\
\hline Income $(\mathrm{k})$ & $\begin{array}{c}0.234 \\
(0.397)\end{array}$ & $\begin{array}{l}-0.000 \\
(0.000)\end{array}$ & $\begin{array}{l}-0.004 \\
(0.022)\end{array}$ & $\begin{array}{l}-0.042 \\
(0.049)\end{array}$ & $\begin{array}{c}0.174^{* * *} \\
(0.033)\end{array}$ & $\begin{array}{c}0.011 \\
(0.011)\end{array}$ & $\begin{array}{c}0.011 \\
(0.011)\end{array}$ \\
\hline Mismatch as \%mean & 2.86 & 0.01 & 1.02 & 1.07 & 1.38 & 30.5 & 33.88 \\
\hline$R^{2}$ & 0.913 & 0.075 & 0.673 & 0.777 & 0.817 & 0.251 & 0.954 \\
\hline Outcome mean & 191.548 & 199.997 & 28.088 & 70.61 & 47.262 & -1.071 & 0.956 \\
\hline $\mathrm{N}$ obs & 41,265 & 40,854 & 126,179 & 146,475 & 138,241 & 170,106 & 210,970 \\
\hline N cluster (county) & 3059 & 3033 & 3059 & 3059 & 3059 & 3058 & 3058 \\
\hline County FE & $\mathrm{Y}$ & $\mathrm{Y}$ & $\mathrm{Y}$ & $\mathrm{Y}$ & $\mathrm{Y}$ & $\mathrm{Y}$ & $\mathrm{Y}$ \\
\hline Year FE & $\mathrm{Y}$ & $\mathrm{Y}$ & $\mathrm{N}$ & $\mathrm{N}$ & $\mathrm{N}$ & $\mathrm{N}$ & $\mathrm{N}$ \\
\hline Firm age $\times$ Year FE & $\mathrm{N}$ & $\mathrm{N}$ & $\mathrm{Y}$ & $\mathrm{Y}$ & $\mathrm{Y}$ & $\mathrm{Y}$ & $\mathrm{Y}$ \\
\hline Industry share & $\mathrm{Y}$ & $\mathrm{Y}$ & $\mathrm{Y}$ & $\mathrm{Y}$ & $\mathrm{Y}$ & $\mathrm{Y}$ & $\mathrm{Y}$ \\
\hline
\end{tabular}

Note: This table examines how the entry, exit, expansion, and contraction of employer firms relate to being in counties that are politically mismatched with the sitting president between 2005 and 2018. "Firm entry", "Estab. entry", "Estab. exit", and "Firm death" are the annual number of new firms, newly opened establishments among existing firms, newly closed establishments among existing firms, and firms that have closed all their establishments, per 100,000 county residents ages 20 or above, respectively. "Job creation rate" is the number of newly created jobs as a percentage of the average employment between years $t$ and $t-1$. "Net job creation rate" is the difference between the number of newly created jobs and the number of newly destroyed jobs as a percentage of average employment between years $t$ and $t-1$. The regression weight for outcomes "Job creation rate" and "Net job creation rate" is average employment in years t and t- 1 ; the regression weight for other outcomes is the county population aged 20 or more. Columns (1) and (2) control for county fixed effects, year fixed effects, and county economic conditions (i.e., annual unemployment rate, income per capita, and employment share for NAICS-2 industries). Columns (3) through (7) replace year fixed effects with firm age-by-year fixed effects. Standard errors are clustered by county. 
Table 7

Political mismatch and the probability of starting firms by Industry

\begin{tabular}{|c|c|c|c|c|c|c|c|c|c|c|c|c|c|}
\hline VARIABLES & $\begin{array}{c}(1) \\
\text { Science \& } \\
\text { Tech }\end{array}$ & $\begin{array}{c}(2) \\
\text { Real } \\
\text { estate }\end{array}$ & $\begin{array}{c}(3) \\
\text { Health \& } \\
\text { Social }\end{array}$ & $\begin{array}{c}(4) \\
\text { Cons- } \\
\text { truction }\end{array}$ & $\begin{array}{c}(5) \\
\text { Other } \\
\text { service }\end{array}$ & $\begin{array}{c}(6) \\
\text { Fin. \& } \\
\text { Insurance }\end{array}$ & $\begin{array}{l}(7) \\
\text { Retail } \\
\text { trade }\end{array}$ & $\begin{array}{c}(8) \\
\text { Accom. \& } \\
\text { Food }\end{array}$ & $\begin{array}{c}(9) \\
\text { Agri- } \\
\text { culture }\end{array}$ & $\begin{array}{l}(10) \\
\text { Public } \\
\text { admin. }\end{array}$ & $\begin{array}{c}(11) \\
\text { Trans- } \\
\text { portation }\end{array}$ & $\begin{array}{c}(12) \\
\text { Admin. }\end{array}$ & $\begin{array}{c}(13) \\
\text { Arts \& } \\
\text { Entmt. }\end{array}$ \\
\hline Mismatch & $\begin{array}{l}-0.0001 \\
(0.0004)\end{array}$ & $\begin{array}{c}-0.0026^{* * *} \\
(0.0004)\end{array}$ & $\begin{array}{c}-0.0016^{* * *} \\
(0.0003)\end{array}$ & $\begin{array}{c}-0.0048^{* * *} \\
(0.0003)\end{array}$ & $\begin{array}{c}-0.0025^{* * *} \\
(0.0003)\end{array}$ & $\begin{array}{c}-0.0018^{* * *} \\
(0.0003)\end{array}$ & $\begin{array}{c}-0.0007^{* * *} \\
(0.0002)\end{array}$ & $\begin{array}{l}-0.0002 \\
(0.0002)\end{array}$ & $\begin{array}{c}0.0006 * * * \\
(0.0002)\end{array}$ & $\begin{array}{c}-0.0004^{* *} \\
(0.0001)\end{array}$ & $\begin{array}{c}-0.0006^{* * *} \\
(0.0002)\end{array}$ & $\begin{array}{c}-0.0006^{* * *} \\
(0.0001)\end{array}$ & $\begin{array}{l}-0.0000 \\
(0.0001)\end{array}$ \\
\hline Dem & $\begin{array}{c}-0.0123^{* * *} \\
(0.0008)\end{array}$ & $\begin{array}{c}-0.0232^{* * *} \\
(0.0011)\end{array}$ & $\begin{array}{c}-0.0106^{* * *} \\
(0.0007)\end{array}$ & $\begin{array}{c}-0.0150 * * * \\
(0.0006)\end{array}$ & $\begin{array}{c}-0.0090^{* * *} \\
(0.0005)\end{array}$ & $\begin{array}{c}-0.0168^{* * *} \\
(0.0011)\end{array}$ & $\begin{array}{c}-0.0043^{* * *} \\
(0.0003)\end{array}$ & $\begin{array}{c}-0.0030^{* * *} \\
(0.0003)\end{array}$ & $\begin{array}{c}-0.0070^{* * *} \\
(0.0003)\end{array}$ & $\begin{array}{c}-0.0046^{* * *} \\
(0.0002)\end{array}$ & $\begin{array}{c}-0.0005^{* *} \\
(0.0003)\end{array}$ & $\begin{array}{c}-0.0034^{* * *} \\
(0.0002)\end{array}$ & $\begin{array}{c}-0.0016^{* * * *} \\
(0.0002)\end{array}$ \\
\hline Male & $\begin{array}{c}0.0387^{* * *} \\
(0.0020)\end{array}$ & $\begin{array}{c}0.0399 * * * \\
(0.0018)\end{array}$ & $\begin{array}{c}0.0185^{* * *} \\
(0.0013)\end{array}$ & $\begin{array}{c}0.0526^{* * * *} \\
(0.0019)\end{array}$ & $\begin{array}{c}0.0217^{* * *} \\
(0.0011)\end{array}$ & $\begin{array}{c}0.0336^{* * *} \\
(0.0023)\end{array}$ & $\begin{array}{c}0.0153^{* * *} \\
(0.0009)\end{array}$ & $\begin{array}{c}0.0135^{* * *} \\
(0.0008)\end{array}$ & $\begin{array}{c}0.0124^{* * *} \\
(0.0005)\end{array}$ & $\begin{array}{c}0.0122^{* * *} \\
(0.0005)\end{array}$ & $\begin{array}{c}0.0144^{* * *} \\
(0.0007)\end{array}$ & $\begin{array}{c}0.0115^{* * *} \\
(0.0005)\end{array}$ & $\begin{array}{c}0.0059 * * * \\
(0.0004)\end{array}$ \\
\hline Age 18-29 & $\begin{array}{c}-0.0052^{* * * *} \\
(0.0009)\end{array}$ & $\begin{array}{c}-0.0147^{* * *} \\
(0.0009)\end{array}$ & $\begin{array}{c}-0.0078^{* * * *} \\
(0.0008)\end{array}$ & $\begin{array}{c}0.0054^{* * *} \\
(0.0006)\end{array}$ & $\begin{array}{c}-0.0035^{* * *} \\
(0.0006)\end{array}$ & $\begin{array}{c}-0.0059^{* * *} \\
(0.0007)\end{array}$ & $\begin{array}{l}0.0006^{*} \\
(0.0003)\end{array}$ & $\begin{array}{c}-0.0013^{* * *} \\
(0.0002)\end{array}$ & $\begin{array}{c}-0.0026 * * * \\
(0.0003)\end{array}$ & $\begin{array}{c}-0.0032^{* * *} \\
(0.0003)\end{array}$ & $\begin{array}{c}0.0007 * * * \\
(0.0002)\end{array}$ & $\begin{array}{c}0.0031^{* * *} \\
(0.0003)\end{array}$ & $\begin{array}{c}0.0020^{* * *} \\
(0.0003)\end{array}$ \\
\hline Age $30-39$ & $\begin{array}{c}0.0432 * * * \\
(0.0024)\end{array}$ & $\begin{array}{c}0.0192^{* * *} \\
(0.0009)\end{array}$ & $\begin{array}{c}0.0284^{* * *} \\
(0.0016)\end{array}$ & $\begin{array}{c}0.0352 * * * \\
(0.0013)\end{array}$ & $\begin{array}{c}0.0227^{* * *} \\
(0.0012)\end{array}$ & $\begin{array}{c}0.0191 * * * \\
(0.0012)\end{array}$ & $\begin{array}{c}0.0138^{* * * *} \\
(0.0007)\end{array}$ & $\begin{array}{c}0.0115^{* * *} \\
(0.0006)\end{array}$ & $\begin{array}{c}0.0039 * * * \\
(0.0003)\end{array}$ & $\begin{array}{c}0.0065^{* * * *} \\
(0.0003)\end{array}$ & $\begin{array}{c}0.0098 * * * \\
(0.0005)\end{array}$ & $\begin{array}{c}0.0107^{* * *} \\
(0.0005)\end{array}$ & $\begin{array}{c}0.0075 * * * \\
(0.0005)\end{array}$ \\
\hline Age $40-49$ & $\begin{array}{c}0.0356^{* * *} \\
(0.0018)\end{array}$ & $\begin{array}{c}0.0242^{* * * *} \\
(0.0010)\end{array}$ & $\begin{array}{c}0.0262^{* * *} \\
(0.0014)\end{array}$ & $\begin{array}{c}0.0306^{* * * *} \\
(0.0011)\end{array}$ & $\begin{array}{c}0.0218^{* * *} \\
(0.0010)\end{array}$ & $\begin{array}{c}0.0189 * * * \\
(0.0012)\end{array}$ & $\begin{array}{c}0.0135^{* * * *} \\
(0.0006)\end{array}$ & $\begin{array}{c}0.0130 * * * \\
(0.0006)\end{array}$ & $\begin{array}{c}0.0040^{* * *} \\
(0.0003)\end{array}$ & $\begin{array}{c}0.0071^{* * * *} \\
(0.0003)\end{array}$ & $\begin{array}{c}0.0098^{* * *} \\
(0.0004)\end{array}$ & $\begin{array}{c}0.0088^{* * *} \\
(0.0004)\end{array}$ & $\begin{array}{c}0.0060^{* * *} \\
(0.0003)\end{array}$ \\
\hline Age 50-59 & $\begin{array}{c}0.0203^{* * *} \\
(0.0010)\end{array}$ & $\begin{array}{c}0.0175 * * * \\
(0.0007)\end{array}$ & $\begin{array}{c}0.0161^{* * *} \\
(0.0008)\end{array}$ & $\begin{array}{c}0.0177^{* * *} \\
(0.0006)\end{array}$ & $\begin{array}{c}0.0130 * * * \\
(0.0006)\end{array}$ & $\begin{array}{c}0.0116^{* * *} \\
(0.0007)\end{array}$ & $\begin{array}{c}0.0079 * * * \\
(0.0004)\end{array}$ & $\begin{array}{c}0.0080 * * * \\
(0.0004)\end{array}$ & $\begin{array}{c}0.0046^{* * *} \\
(0.0003)\end{array}$ & $\begin{array}{c}0.0044^{* * * *} \\
(0.0002)\end{array}$ & $\begin{array}{c}0.0056^{* * *} \\
(0.0002)\end{array}$ & $\begin{array}{c}0.0049^{* * *} \\
(0.0003)\end{array}$ & $\begin{array}{c}0.0028^{* * *} \\
(0.0002)\end{array}$ \\
\hline Mi race & $\begin{array}{c}0.0061^{* * *} \\
(0.0012)\end{array}$ & $\begin{array}{c}0.0068^{* * * *} \\
(0.0019)\end{array}$ & $\begin{array}{c}0.0096^{* * *} \\
(0.0018)\end{array}$ & $\begin{array}{l}-0.0003 \\
(0.0009)\end{array}$ & $\begin{array}{c}0.0033^{* * *} \\
(0.0010)\end{array}$ & $\begin{array}{c}0.0071^{* * * *} \\
(0.0020)\end{array}$ & $\begin{array}{c}0.0057^{* * *} \\
(0.0010)\end{array}$ & $\begin{array}{c}0.0033^{* * *} \\
(0.0006)\end{array}$ & $\begin{array}{c}-0.0014^{* * *} \\
(0.0003)\end{array}$ & $\begin{array}{l}0.0008^{*} \\
(0.0005)\end{array}$ & $\begin{array}{c}0.0021^{* * *} \\
(0.0006)\end{array}$ & $\begin{array}{l}-0.0002 \\
(0.0002)\end{array}$ & $\begin{array}{l}-0.0001 \\
(0.0002)\end{array}$ \\
\hline Asian & $\begin{array}{c}0.0112^{* * *} \\
(0.0023)\end{array}$ & $\begin{array}{c}0.0145 * * * \\
(0.0025)\end{array}$ & $\begin{array}{c}0.0258^{* * *} \\
(0.0028)\end{array}$ & $\begin{array}{c}-0.0078^{* * *} \\
(0.0012)\end{array}$ & $\begin{array}{c}0.0174 * * * \\
(0.0016)\end{array}$ & $\begin{array}{c}0.0234 * * * \\
(0.0028)\end{array}$ & $\begin{array}{c}0.0125^{* * * *} \\
(0.0012)\end{array}$ & $\begin{array}{c}0.0317^{* * * *} \\
(0.0019)\end{array}$ & $\begin{array}{c}-0.0033^{* * *} \\
(0.0006)\end{array}$ & $\begin{array}{c}0.0018^{* *} \\
(0.0008)\end{array}$ & $\begin{array}{c}0.0042^{* * * *} \\
(0.0011)\end{array}$ & $\begin{array}{c}-0.0028^{* * *} \\
(0.0004)\end{array}$ & $\begin{array}{c}-0.0019^{* * * *} \\
(0.0005)\end{array}$ \\
\hline Black & $\begin{array}{c}-0.0264^{* * *} \\
(0.0029)\end{array}$ & $\begin{array}{c}-0.0229 * * * \\
(0.0021)\end{array}$ & $\begin{array}{c}0.0020 \\
(0.0019)\end{array}$ & $\begin{array}{c}-0.0135^{* * *} \\
(0.0013)\end{array}$ & $\begin{array}{c}0.0127^{* * *} \\
(0.0016)\end{array}$ & $\begin{array}{c}-0.0081^{* * *} \\
(0.0019)\end{array}$ & $\begin{array}{c}-0.0045^{* * *} \\
(0.0008)\end{array}$ & $\begin{array}{c}-0.0060^{* * *} \\
(0.0008)\end{array}$ & $\begin{array}{c}-0.0070^{* * *} \\
(0.0006)\end{array}$ & $\begin{array}{c}-0.0049^{* * *} \\
(0.0006)\end{array}$ & $\begin{array}{c}0.0075 * * * \\
(0.0010)\end{array}$ & $\begin{array}{c}-0.0024^{* * *} \\
(0.0004)\end{array}$ & $\begin{array}{l}-0.0001 \\
(0.0004)\end{array}$ \\
\hline Hispanic & $\begin{array}{c}-0.0291^{* * *} \\
(0.0027)\end{array}$ & $\begin{array}{c}-0.0214^{* * *} \\
(0.0018)\end{array}$ & $\begin{array}{c}-0.0160^{* * *} \\
(0.0027)\end{array}$ & $\begin{array}{l}-0.0029 \\
(0.0023)\end{array}$ & $\begin{array}{c}-0.0098^{* * *} \\
(0.0013)\end{array}$ & $\begin{array}{c}-0.0141^{* * *} \\
(0.0023)\end{array}$ & $\begin{array}{c}-0.0050^{* * * *} \\
(0.0010)\end{array}$ & $\begin{array}{c}-0.0034^{* * *} \\
(0.0011)\end{array}$ & $\begin{array}{c}-0.0098^{* * *} \\
(0.0006)\end{array}$ & $\begin{array}{c}-0.0074^{* * *} \\
(0.0005)\end{array}$ & $\begin{array}{c}0.0032^{* * *} \\
(0.0012)\end{array}$ & $\begin{array}{c}-0.0021^{* * *} \\
(0.0005)\end{array}$ & $\begin{array}{c}-0.0048^{* * *} \\
(0.0005)\end{array}$ \\
\hline Mismatch as \%mean & .21 & 6.02 & 4.21 & 13.18 & 7.59 & 6.04 & 3.7 & .97 & 4.4 & 2.86 & 5.15 & 5.56 & .35 \\
\hline$R^{2}$ & 0.020 & 0.015 & 0.011 & & 0.0 & 0.015 & 0.006 & 0.005 & 0.008 & 0.005 & 0.006 & 0.006 & 0.004 \\
\hline Outcome mean & .051 & .043 & .038 & .036 & .033 & .029 & .017 & .016 & .012 & .012 & .011 & .01 & .007 \\
\hline $\mathrm{N}$ obs & $327,127,995$ & $327,127,995$ & $327,127,995$ & $327,127,995$ & $327,127,995$ & $327,127,995$ & $327,127,995$ & $327,127,995$ & $327,127,995$ & $327,127,995$ & $327,127,995$ & $327,127,995$ & $327,127,995$ \\
\hline $\mathrm{N}$ cluste & 2,120 & 2,120 & 2,120 & 2,120 & 2,120 & 2,120 & 2,120 & 2,120 & 2,120 & 2,120 & 2,120 & 2,120 & 2,120 \\
\hline County $\times$ Year FE & $\mathrm{Y}$ & $\mathrm{Y}$ & $\mathrm{Y}$ & $\mathrm{Y}$ & $\mathrm{Y}$ & $\mathrm{Y}$ & $\mathrm{Y}$ & $\mathrm{Y}$ & $\mathrm{Y}$ & $\mathrm{Y}$ & $\mathrm{Y}$ & $\mathrm{Y}$ & Y \\
\hline
\end{tabular}

Note: This table examines how individuals' annual probability of starting businesses in different NAICS-2 industries relates to being politically mismatched with the sitting president. It is identical to the specification in Table 3 panel A column (1) except that the dependent variable is the annual probability of starting firms in a specific industry, which differs by column. Units are in percentage points. Firms are classified into industries based on the presence of industry-specific keywords in their names (see section 5 ).

We report the 13 most populated industries in our sample. 
INTERNET APPENDIX FOR "PARTISAN ENTREPRENEURSHIP"

by Joseph Engelberg, Jorge Guzman, Runjing Lu and William Mullins 


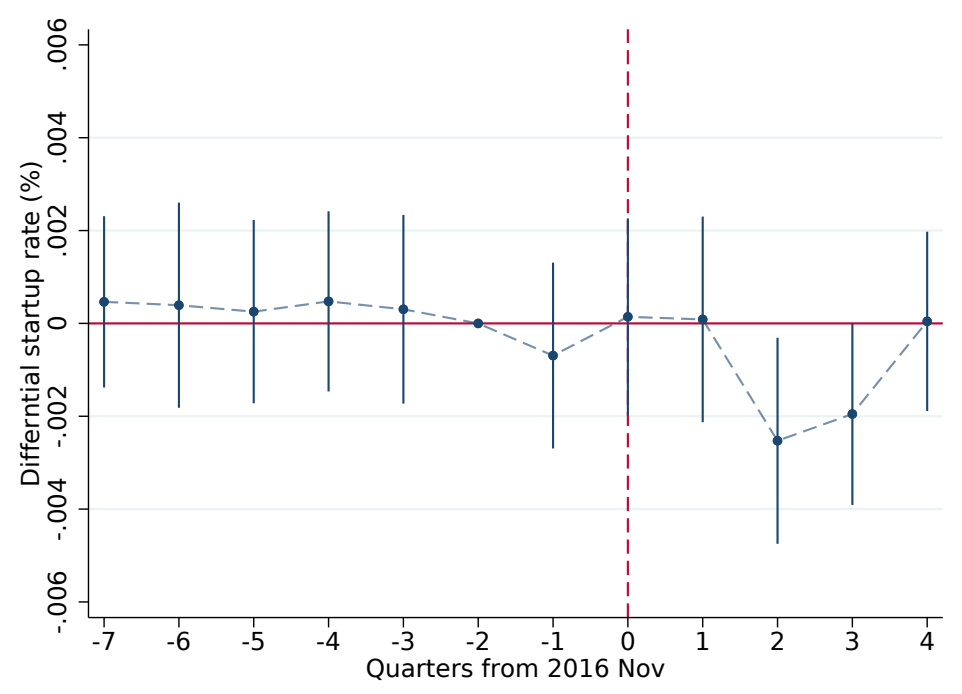

(a) 2016 election

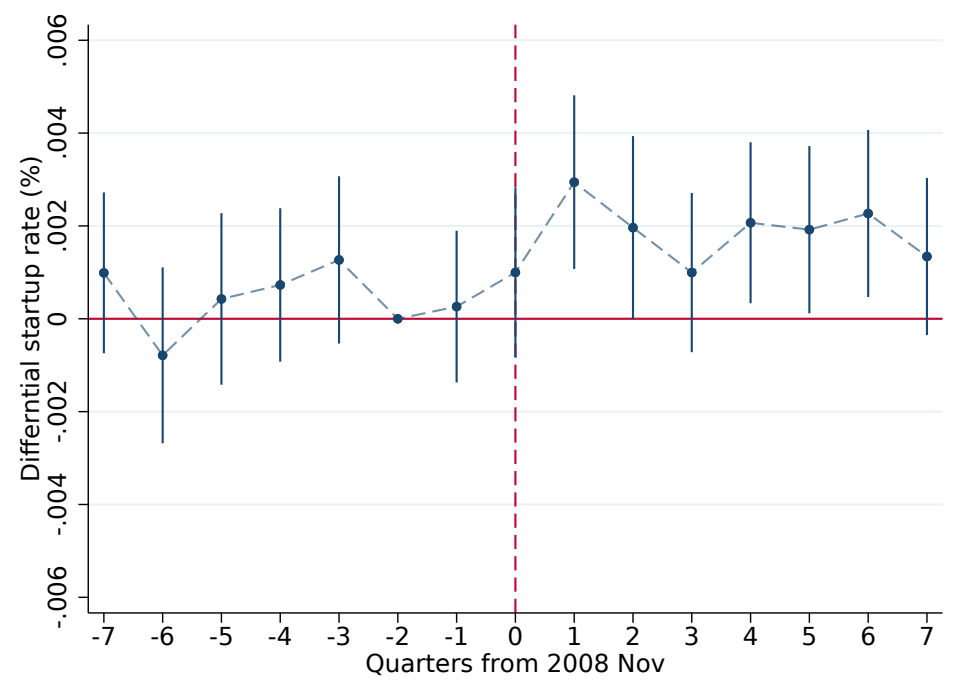

(b) 2008 election

Figure A1. Political mismatch and the probability of starting a business: Active Democrat vs. active Republican individuals

Note: This figure plots the coefficient on the Democrat indicator from equation 1 (at each event-time), capturing active Democrats' excess probability of starting a business relative to active Republican voters (omitted group). Units are in percentage points. Active partisans are defined as those who vote in an abovemedian percentage of their available even-year general and primary elections as of 2020. Event time 0 refers to the month of a presidential election, plus the two subsequent months. For example, for the 2016 election event time 0 is November 2016 to January 2017. Event time -2 is the omitted period. All regressions control for county $\times$ event time fixed effects and personal characteristics (gender, age groups, race). Regressions are run at the county-party-characteristic-month cell and are weighted by the number of observations in each cell. Standard errors are clustered by county. 


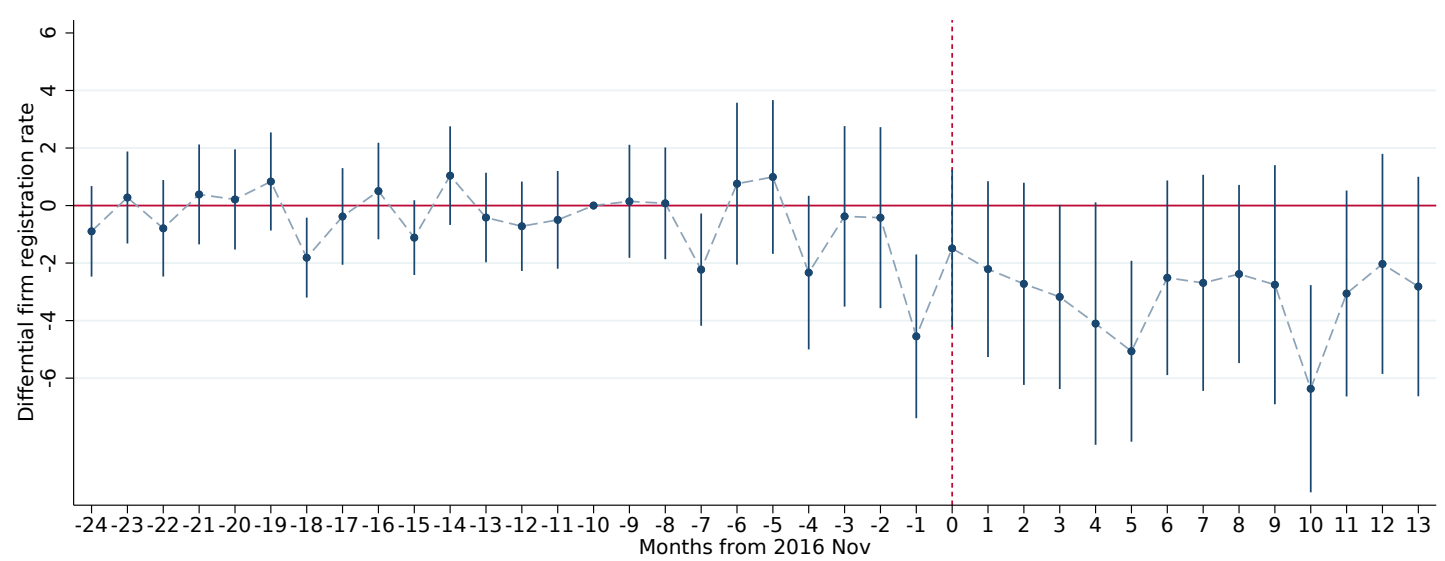

(a) 2016 election

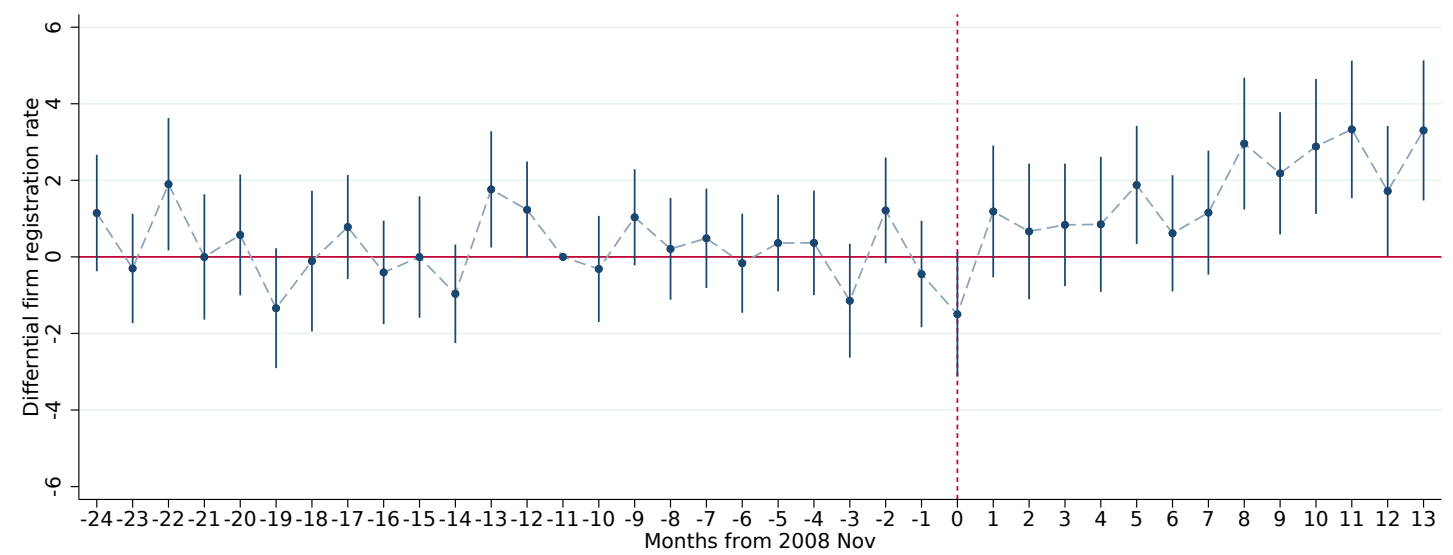

(b) 2008 election

Figure A2. Political mismatch and new firms

Democratic vs. Republican counties (monthly frequency)

Note: This figure plots the the monthly counterpart of Figure 5, capturing Democratic-leaning counties' startup rates relative to Republican-leaning counties (omitted group) in each month. Event time 0 refers to the month of a presidential election; the omitted period is the month before the first presidential primary/caucus election in the respective election season (Iowa caucus on January 3, 2008 and Iowa caucus on February 1, 2016), i.e., event -10 for the 2008 election and -11 for the 2016 . All regressions control for county fixed effects, event time fixed effects, and county economic conditions (monthly unemployment rate, annual per capita income, and annual employment share for 2-digit NAICS industries). Regressions are weighted by county population ages 20 and above. Standard errors are clustered by county. 


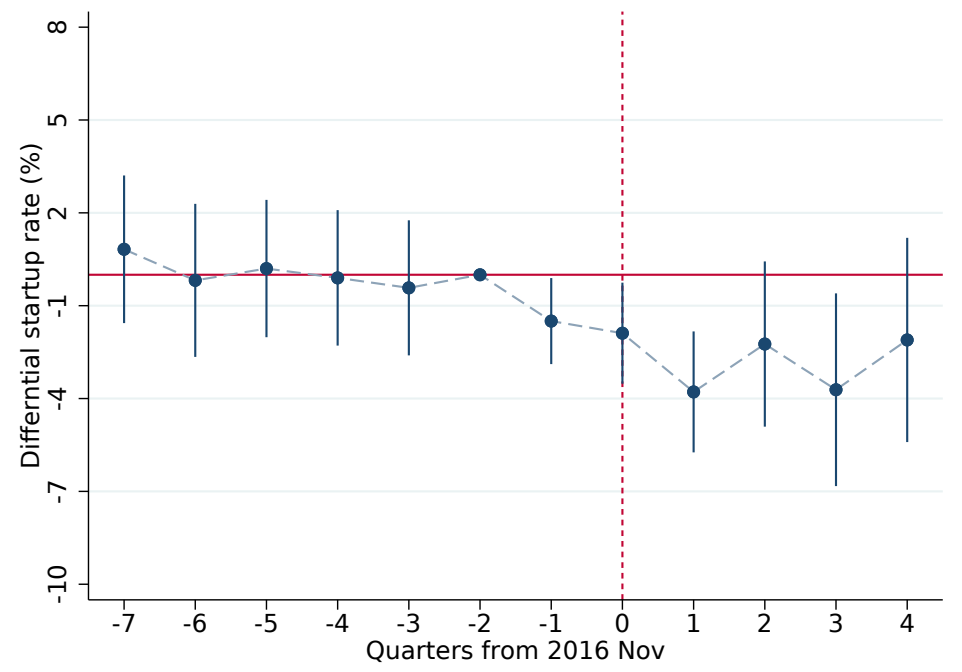

(a) 2016 election

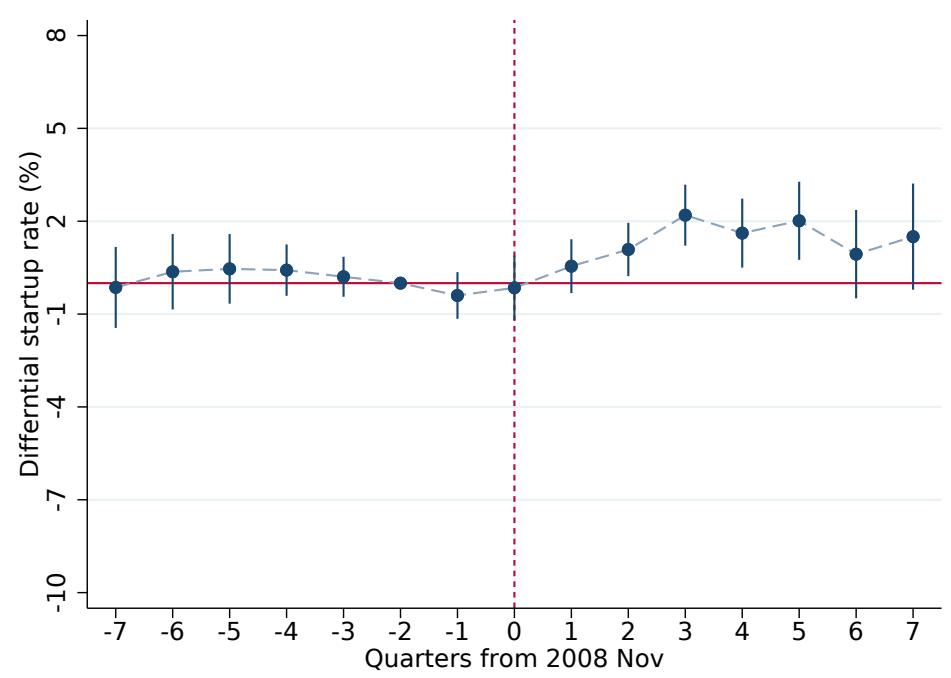

(b) 2008 election

Figure A3. Political mismatch and new firms

Democratic vs. Republican counties (excluding economic controls)

Note: This figure presents a robustness check for Figure 5. All specifications are the same except that we exclude controls for county economic conditions in this figure. 
Table A1

Voter characteristics across samples

\begin{tabular}{|c|c|c|c|}
\hline & $\%$ All parties & $\%$ Democrat & $\%$ Republican \\
\hline \multicolumn{4}{|c|}{ Panel A: All US voters } \\
\hline Male & 46.57 & 41.81 & 49.97 \\
\hline White & 75.80 & 61.76 & 91.19 \\
\hline Black & 10.39 & 19.42 & 1.42 \\
\hline Hispanic & 10.97 & 16.13 & 5.55 \\
\hline Asian & 2.83 & 2.69 & 1.84 \\
\hline Cohort 1990+ & 7.37 & 6.87 & 4.63 \\
\hline Cohort 1980-89 & 15.00 & 14.74 & 9.88 \\
\hline Cohort 1970-79 & 15.33 & 14.26 & 13.09 \\
\hline Cohort 1960-69 & 18.77 & 17.54 & 20.55 \\
\hline Cohort 1950-59 & 19.24 & 20.03 & 21.57 \\
\hline Cohort 1940- & 24.30 & 26.56 & 30.29 \\
\hline $\mathrm{N}$ voter & $159,029,424$ & $61,168,464$ & $49,201,960$ \\
\hline N State & 51 & 51 & 51 \\
\hline \multicolumn{4}{|c|}{ Panel B: Voters in sample states } \\
\hline Male & 46.68 & 41.90 & 49.82 \\
\hline White & 75.40 & 62.05 & 90.06 \\
\hline Black & 9.30 & 16.33 & 1.39 \\
\hline Hispanic & 12.37 & 18.83 & 6.53 \\
\hline Asian & 2.93 & 2.79 & 2.02 \\
\hline Cohort $1990+$ & 7.42 & 6.80 & 4.73 \\
\hline Cohort 1980-89 & 15.11 & 14.77 & 10.11 \\
\hline Cohort 1970-79 & 15.25 & 14.20 & 13.14 \\
\hline Cohort 1960-69 & 18.54 & 17.39 & 20.20 \\
\hline Cohort 1950-59 & 19.21 & 20.09 & 21.36 \\
\hline Cohort 1940- & 24.46 & 26.74 & 30.46 \\
\hline $\mathrm{N}$ voter & $107,914,168$ & $40,744,516$ & $34,203,120$ \\
\hline N State & 33 & 33 & 33 \\
\hline \multicolumn{4}{|c|}{ Panel C: Voters in regression sample } \\
\hline Male & 41.32 & 36.15 & 44.62 \\
\hline White & 75.81 & 62.46 & 91 \\
\hline Black & 11.07 & 19.82 & 1.50 \\
\hline Hispanic & 9.40 & 13.99 & 5.08 \\
\hline Asian & 3.72 & 3.73 & 2.41 \\
\hline Cohort $1990+$ & 7.88 & 7.44 & 4.79 \\
\hline Cohort 1980-89 & 15.26 & 15.45 & 10.06 \\
\hline Cohort 1970-79 & 17.09 & 16.17 & 14.98 \\
\hline Cohort 1960-69 & 20.53 & 19.22 & 22.94 \\
\hline Cohort 1950-59 & 20.97 & 22.05 & 23.90 \\
\hline Cohort 1940- & 18.27 & 19.67 & 23.32 \\
\hline $\mathrm{N}$ voter & $40,420,508$ & $14,696,895$ & $13,083,051$ \\
\hline N State & 33 & 33 & 33 \\
\hline
\end{tabular}

Note: This table reports summary statistics of demographics for all voters in L2's 2014 voter file (panel A), voters in counties included in our regression sample (panel B), and voters in our regression sample (panel C). See section 2 for sample construction and note to Table 1 for variable definitions. 


\section{Table A2}

\section{Political mismatch and the probability of starting a business Democrat vs. Republican Individuals}

\begin{tabular}{|c|c|c|}
\hline & $\begin{array}{c}(1) \\
\text { Election } 2008\end{array}$ & $\begin{array}{c}(2) \\
\text { Election } 2016\end{array}$ \\
\hline Dem $\times-7 Q$ & $\begin{array}{l}-0.00001 \\
(0.00071)\end{array}$ & $\begin{array}{c}0.00005 \\
(0.00075)\end{array}$ \\
\hline Dem $\times-6 Q$ & $\begin{array}{l}-0.00113 \\
(0.00079)\end{array}$ & $\begin{array}{c}0.00047 \\
(0.00077)\end{array}$ \\
\hline Dem $\times-5 Q$ & $\begin{array}{l}-0.00042 \\
(0.00071)\end{array}$ & $\begin{array}{c}0.00039 \\
(0.00072)\end{array}$ \\
\hline Dem $\times-4 Q$ & $\begin{array}{l}-0.00099 \\
(0.00064)\end{array}$ & $\begin{array}{c}0.00101 \\
(0.00068)\end{array}$ \\
\hline Dem $\times-3 Q$ & $\begin{array}{l}-0.00009 \\
(0.00070)\end{array}$ & $\begin{array}{c}0.00070 \\
(0.00074)\end{array}$ \\
\hline Dem $\times-1 Q$ & $\begin{array}{l}-0.00002 \\
(0.00064)\end{array}$ & $\begin{array}{l}-0.00042 \\
(0.00075)\end{array}$ \\
\hline Dem $\times 0 \mathrm{Q}$ & $\begin{array}{c}0.00097 \\
(0.00071)\end{array}$ & $\begin{array}{l}-0.00055 \\
(0.00074)\end{array}$ \\
\hline $\operatorname{Dem} \times 1 \mathrm{Q}$ & $\begin{array}{c}0.00148^{* *} \\
(0.00068)\end{array}$ & $\begin{array}{l}-0.00045 \\
(0.00074)\end{array}$ \\
\hline $\operatorname{Dem} \times 2 \mathrm{Q}$ & $\begin{array}{l}0.00144^{*} \\
(0.00077)\end{array}$ & $\begin{array}{c}-0.00240^{* * *} \\
(0.00083)\end{array}$ \\
\hline $\operatorname{Dem} \times 3 \mathrm{Q}$ & $\begin{array}{c}0.00101 \\
(0.00063)\end{array}$ & $\begin{array}{l}-0.00123^{*} \\
(0.00072)\end{array}$ \\
\hline $\operatorname{Dem} \times 4 \mathrm{Q}$ & $\begin{array}{c}0.00154^{* *} \\
(0.00067)\end{array}$ & $\begin{array}{l}-0.00052 \\
(0.00073)\end{array}$ \\
\hline $\operatorname{Dem} \times 5 \mathrm{Q}$ & $\begin{array}{c}0.00047 \\
(0.00069)\end{array}$ & \\
\hline Dem $\times 6 Q$ & $\begin{array}{c}0.00099 \\
(0.00066)\end{array}$ & \\
\hline $\operatorname{Dem} \times 7 \mathrm{Q}$ & $\begin{array}{c}0.00007 \\
(0.00068)\end{array}$ & \\
\hline Avg $1-4 \mathrm{Q}$ as $\%$ mean & 3.35 & -2.38 \\
\hline$R^{2}$ & 0.004 & 0.004 \\
\hline Outcome mean & .04 & .048 \\
\hline $\mathrm{N}$ obs & $1,156,960,752$ & $864,092,632$ \\
\hline $\mathrm{N}$ cluster (county) & 2,119 & 2,118 \\
\hline Demographics & $\mathrm{Y}$ & Y \\
\hline County $\times$ Event FE & $\mathrm{Y}$ & Y \\
\hline
\end{tabular}

Note: This table provides coefficient estimates from the individual-level DID described by equation 1 (also see Figure 2). Units are in percentage points and the omitted group is Republican individuals. Event time 0 denotes the three months following the month of a presidential election. For example, for the 2016 election event time 0 is November 2016 to January 2017 . Event time -2 is the omitted period. All regressions control for county $\times$ event fixed effects and voter characteristics (i.e., gender, age groups, race). Regressions are run at the county-party-characteristic-month cell and are weighted by the number of observations in each cell. Standard errors are clustered by county. 
Table A3

Political mismatch and the probability of starting a business

By household income

\begin{tabular}{|c|c|c|c|c|c|c|c|c|}
\hline & \multirow[t]{2}{*}{$(1)$} & \multirow{2}{*}{\multicolumn{2}{|c|}{$\begin{array}{c}(2) \\
\text { High household income }\end{array}$}} & \multirow[t]{2}{*}{$(4)$} & \multirow{2}{*}{\multicolumn{3}{|c|}{$\begin{array}{c}(6) \\
\text { Low household income }\end{array}$}} & \multirow{3}{*}{$\begin{array}{c}\text { (8) } \\
\text { FEC voter }\end{array}$} \\
\hline & & & & & & & & \\
\hline & Regular voter & Active voter & Donor voter & FEC voter & Regular voter & Active voter & Donor voter & \\
\hline Mismatch & $\begin{array}{c}-0.0223^{* * *} \\
(0.0029)\end{array}$ & $\begin{array}{c}-0.0149 * * * \\
(0.0034)\end{array}$ & $\begin{array}{c}-0.0194 * * * \\
(0.0036)\end{array}$ & $\begin{array}{c}-0.0194^{* * *} \\
(0.0027)\end{array}$ & $\begin{array}{c}-0.0145^{* * *} \\
(0.0012)\end{array}$ & $\begin{array}{c}-0.0118^{* * *} \\
(0.0014)\end{array}$ & $\begin{array}{c}-0.0122^{* * *} \\
(0.0015)\end{array}$ & $\begin{array}{c}-0.0138^{* * *} \\
(0.0012)\end{array}$ \\
\hline Mismatch $\times$ Active & & $\begin{array}{c}-0.0151^{* * *} \\
(0.0040)\end{array}$ & $\begin{array}{l}-0.0063 \\
(0.0041)\end{array}$ & $\begin{array}{c}-0.0524^{* * *} \\
(0.0171)\end{array}$ & & $\begin{array}{c}-0.0054^{* * *} \\
(0.0019)\end{array}$ & $\begin{array}{c}-0.0063^{* * *} \\
(0.0020)\end{array}$ & $\begin{array}{l}-0.0226 \\
(0.0142)\end{array}$ \\
\hline Dem & $\begin{array}{c}-0.1755^{* * *} \\
(0.0092)\end{array}$ & $\begin{array}{c}-0.1628^{* * *} \\
(0.0109)\end{array}$ & $\begin{array}{c}-0.1778^{* * *} \\
(0.0098)\end{array}$ & $\begin{array}{c}-0.1568^{* * *} \\
(0.0089)\end{array}$ & $\begin{array}{c}-0.1124^{* * *} \\
(0.0046)\end{array}$ & $\begin{array}{c}-0.1083^{* * *} \\
(0.0056)\end{array}$ & $\begin{array}{c}-0.1132^{* * *} \\
(0.0054)\end{array}$ & $\begin{array}{c}-0.1066^{* * *} \\
(0.0045)\end{array}$ \\
\hline Dem $\times$ Active & & $\begin{array}{c}-0.0387^{* * *} \\
(0.0100)\end{array}$ & $\begin{array}{c}0.0095 \\
(0.0066)\end{array}$ & $\begin{array}{c}-0.8082^{* * * *} \\
(0.0490)\end{array}$ & & $\begin{array}{c}-0.0112^{* *} \\
(0.0047)\end{array}$ & $\begin{array}{l}0.0074^{*} \\
(0.0043)\end{array}$ & $\begin{array}{c}-0.4724^{* * * *} \\
(0.0256)\end{array}$ \\
\hline Active & & $\begin{array}{c}0.0929 * * * \\
(0.0143)\end{array}$ & $\begin{array}{c}0.0332^{* * *} \\
(0.0065)\end{array}$ & $\begin{array}{c}1.8234^{* * *} \\
(0.0852)\end{array}$ & & $\begin{array}{c}0.1040^{* * *} \\
(0.0048)\end{array}$ & $\begin{array}{c}0.0320^{* * *} \\
(0.0031)\end{array}$ & $\begin{array}{c}1.1304^{* * * *} \\
(0.0324)\end{array}$ \\
\hline Male & $\begin{array}{c}0.6883^{* * *} \\
(0.0388)\end{array}$ & $\begin{array}{c}0.6893^{* * *} \\
(0.0388)\end{array}$ & $\begin{array}{c}0.6881^{* * * *} \\
(0.0388)\end{array}$ & $\begin{array}{c}0.6617^{* * *} \\
(0.0377)\end{array}$ & $\begin{array}{c}0.2866^{* * *} \\
(0.0113)\end{array}$ & $\begin{array}{c}0.2878^{* * *} \\
(0.0114)\end{array}$ & $\begin{array}{c}0.2859^{* * *} \\
(0.0113)\end{array}$ & $\begin{array}{c}0.2812^{* * *} \\
(0.0113)\end{array}$ \\
\hline Age 18-29 & $\begin{array}{c}-0.1463^{* * *} \\
(0.0125)\end{array}$ & $\begin{array}{c}-0.1161 * * * \\
(0.0137)\end{array}$ & $\begin{array}{c}-0.1381 * * * \\
(0.0125)\end{array}$ & $\begin{array}{c}-0.0651^{* * *} \\
(0.0103)\end{array}$ & $\begin{array}{c}-0.0217^{* * *} \\
(0.0039)\end{array}$ & $\begin{array}{c}0.0200^{* * *} \\
(0.0039)\end{array}$ & $\begin{array}{c}-0.0141^{* * *} \\
(0.0040)\end{array}$ & $\begin{array}{l}-0.0040 \\
(0.0038)\end{array}$ \\
\hline Age $30-39$ & $\begin{array}{c}0.4072^{* * * *} \\
(0.0216)\end{array}$ & $\begin{array}{c}0.4299 * * * \\
(0.0206)\end{array}$ & $\begin{array}{c}0.4140^{* * *} \\
(0.0220)\end{array}$ & $\begin{array}{c}0.4707^{* * *} \\
(0.0244)\end{array}$ & $\begin{array}{c}0.2345^{* * * *} \\
(0.0117)\end{array}$ & $\begin{array}{c}0.2672^{* * * *} \\
(0.0119)\end{array}$ & $\begin{array}{c}0.2409^{* * *} \\
(0.0120)\end{array}$ & $\begin{array}{c}0.2499^{* * * *} \\
(0.0120)\end{array}$ \\
\hline Age $40-49$ & $\begin{array}{c}0.4156^{* * *} \\
(0.0199)\end{array}$ & $\begin{array}{c}0.4313^{* * *} \\
(0.0192)\end{array}$ & $\begin{array}{c}0.4179 * * * \\
(0.0201)\end{array}$ & $\begin{array}{c}0.4607^{* * *} * \\
(0.0221)\end{array}$ & $\begin{array}{c}0.2153^{* * *} \\
(0.0089)\end{array}$ & $\begin{array}{c}0.2380^{* * * *} \\
(0.0091)\end{array}$ & $\begin{array}{c}0.2180^{* * *} \\
(0.0090)\end{array}$ & $\begin{array}{c}0.2282^{* * *} \\
(0.0092)\end{array}$ \\
\hline Age 50-59 & $\begin{array}{c}0.2704^{* * *} * \\
(0.0131)\end{array}$ & $\begin{array}{c}0.2783^{* * *} \\
(0.0127)\end{array}$ & $\begin{array}{c}0.2708^{* * * *} \\
(0.0131)\end{array}$ & $\begin{array}{c}0.2943^{* * *} \\
(0.0142)\end{array}$ & $\begin{array}{c}0.1401^{* * *} * \\
(0.0053)\end{array}$ & $\begin{array}{c}0.1511^{* * * *} \\
(0.0054)\end{array}$ & $\begin{array}{c}0.1407^{* * *} * \\
(0.0053)\end{array}$ & $\begin{array}{c}0.1471^{* * * *} \\
(0.0055)\end{array}$ \\
\hline Asian & $\begin{array}{c}0.2979^{* * * *} \\
(0.0301)\end{array}$ & $\begin{array}{c}0.3052^{* * *} \\
(0.0313)\end{array}$ & $\begin{array}{c}0.2979 * * * \\
(0.0300)\end{array}$ & $\begin{array}{c}0.3078^{* * *} \\
(0.0293)\end{array}$ & $\begin{array}{c}0.1308^{* * *} \\
(0.0107)\end{array}$ & $\begin{array}{c}0.1395^{* * * *} \\
(0.0108)\end{array}$ & $\begin{array}{c}0.1313 * * * \\
(0.0107)\end{array}$ & $\begin{array}{c}0.1330^{* * * *} \\
(0.0107)\end{array}$ \\
\hline Black & $\begin{array}{c}-0.1017^{* * *} \\
(0.0259)\end{array}$ & $\begin{array}{c}-0.1015^{* * *} \\
(0.0259)\end{array}$ & $\begin{array}{c}-0.0984^{* * * *} \\
(0.0258)\end{array}$ & $\begin{array}{c}-0.0766^{* * * *} \\
(0.0253)\end{array}$ & $\begin{array}{c}-0.0860^{* * *} \\
(0.0135)\end{array}$ & $\begin{array}{c}-0.0855^{* * *} \\
(0.0136)\end{array}$ & $\begin{array}{c}-0.0818^{* * *} \\
(0.0133)\end{array}$ & $\begin{array}{c}-0.0802^{* * * *} \\
(0.0134)\end{array}$ \\
\hline Hispanic & $\begin{array}{c}-0.2320^{* * *} \\
(0.0303)\end{array}$ & $\begin{array}{c}-0.2256^{* * *} \\
(0.0313)\end{array}$ & $\begin{array}{c}-0.2265^{* * *} \\
(0.0300)\end{array}$ & $\begin{array}{c}-0.2080^{* * * *} \\
(0.0287)\end{array}$ & $\begin{array}{c}-0.1322^{* * * *} \\
(0.0177)\end{array}$ & $\begin{array}{c}-0.1205^{* * *} \\
(0.0180)\end{array}$ & $\begin{array}{c}-0.1264^{* * * *} \\
(0.0179)\end{array}$ & $\begin{array}{c}-0.1245^{* * *} \\
(0.0176)\end{array}$ \\
\hline Mismatch as \%mean & 2.91 & 1.94 & 2.54 & 2.53 & 4.21 & 3.41 & 3.53 & 3.99 \\
\hline Mismatch $\times$ Active as $\%$ mean & - & 1.97 & .81 & 6.82 & - & 1.56 & 1.81 & 6.54 \\
\hline$R^{2}$ & 0.185 & 0.124 & 0.124 & 0.134 & 0.073 & 0.047 & 0.048 & 0.055 \\
\hline Outcome mean & .767 & .767 & .767 & .767 & .345 & .345 & .345 & .345 \\
\hline $\mathrm{N}$ obs & $114,056,924$ & $113,945,835$ & $114,056,924$ & $114,056,924$ & $205,764,381$ & $205,463,991$ & $205,764,381$ & $205,764,381$ \\
\hline $\mathrm{N}$ cluster (county) & 2,108 & 2,108 & 2,108 & 2,108 & 2,111 & 2,111 & 2,111 & 2,111 \\
\hline County $\times$ Year FE & $\mathrm{Y}$ & $\mathrm{Y}$ & $\mathrm{Y}$ & $\mathrm{Y}$ & $\mathrm{Y}$ & $\mathrm{Y}$ & $\mathrm{Y}$ & $\mathrm{Y}$ \\
\hline
\end{tabular}

Note: This table examines how the annual probability of starting a business relates to being politically mismatched with the sitting president for individuals with different levels of household income. Columns (1) through (4) re-estimate Table 3 panel A columns (1) through (4) for voters whose annual household income is above $\$ 100,000$ and columns (5) through (8) for those whose household income is lower. All specifications and variable definitions mirror those in Table 3 panel A. 


\section{Table A4}

\section{Political mismatch and the probability of starting a business: Alternative geographic fixed effects}

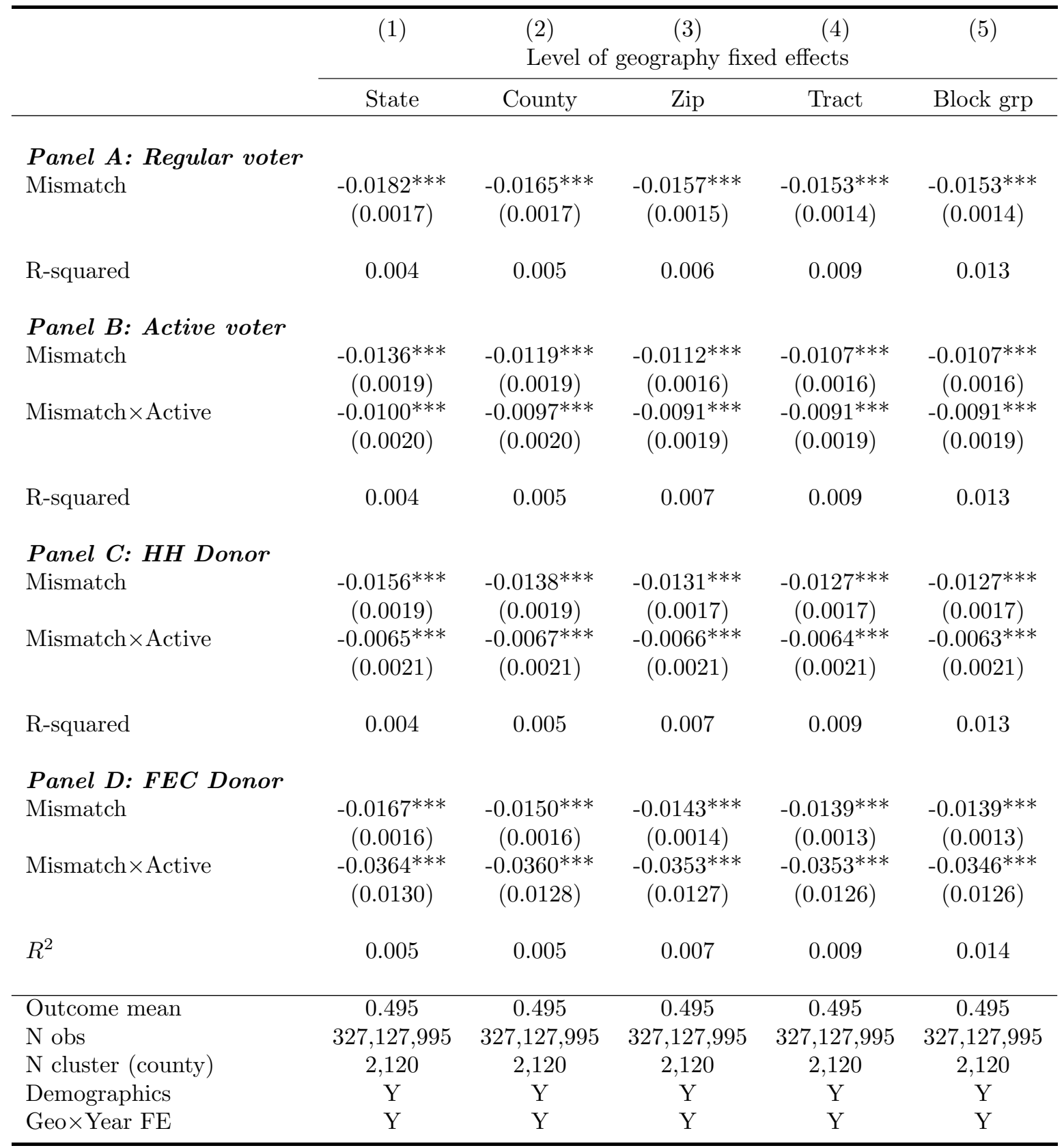

Note: This table presents robustness checks for Table 3 under various geography-by-year fixed effects. Specifications in panels A, B, C, and D mirror Table 3 panel A columns (1), (2), (3), and (4), respectively, except that each column now includes a different set of geography-by-year fixed effects. Columns (1) through (5) control for state-by-year, county-by-year, zip codeby-year, census tract-by-year, and census block group-by-year fixed effects, respectively. Standard errors are clustered by county. 


\section{Table A5}

Political mismatch and the probability of starting a business Alternative name probability cutoffs

\begin{tabular}{|c|c|c|c|c|c|}
\hline & \multicolumn{5}{|c|}{ Name probability cutoff } \\
\hline & .001 & .0005 & .0001 & .00001 & .000001 \\
\hline Mismatch & $\begin{array}{c}-0.0165^{* * *} \\
(0.0017)\end{array}$ & $\begin{array}{c}-0.0159^{* * *} \\
(0.0017)\end{array}$ & $\begin{array}{c}-0.0145^{* * *} \\
(0.0017)\end{array}$ & $\begin{array}{c}-0.0137^{* * *} \\
(0.0019)\end{array}$ & $\begin{array}{c}-0.0130^{* * *} \\
(0.0021)\end{array}$ \\
\hline Dem & $\begin{array}{c}-0.1641^{* * *} \\
(0.0069)\end{array}$ & $\begin{array}{c}-0.1599^{* * *} \\
(0.0067)\end{array}$ & $\begin{array}{c}-0.1512^{* * *} \\
(0.0066)\end{array}$ & $\begin{array}{c}-0.1408^{* * *} \\
(0.0072)\end{array}$ & $\begin{array}{c}-0.1359^{* * *} \\
(0.0078)\end{array}$ \\
\hline Male & $\begin{array}{c}0.4349^{* * *} \\
(0.0207)\end{array}$ & $\begin{array}{c}0.4284^{* * *} \\
(0.0204)\end{array}$ & $\begin{array}{c}0.4132^{* * *} \\
(0.0205)\end{array}$ & $\begin{array}{c}0.3938^{* * *} \\
(0.0213)\end{array}$ & $\begin{array}{c}0.3749^{* * *} \\
(0.0222)\end{array}$ \\
\hline Age 18-29 & $\begin{array}{c}-0.0472^{* * *} \\
(0.0064)\end{array}$ & $\begin{array}{c}-0.0445^{* * *} \\
(0.0064)\end{array}$ & $\begin{array}{c}-0.0388^{* * *} \\
(0.0065)\end{array}$ & $\begin{array}{c}-0.0343^{* * *} \\
(0.0074)\end{array}$ & $\begin{array}{c}-0.0333^{* * *} \\
(0.0086)\end{array}$ \\
\hline Age $30-39$ & $\begin{array}{c}0.3403^{* * *} \\
(0.0158)\end{array}$ & $\begin{array}{c}0.3339^{* * *} \\
(0.0155)\end{array}$ & $\begin{array}{c}0.3185^{* * *} \\
(0.0152)\end{array}$ & $\begin{array}{c}0.2962^{* * *} \\
(0.0155)\end{array}$ & $\begin{array}{c}0.2809^{* * *} \\
(0.0162)\end{array}$ \\
\hline Age $40-49$ & $\begin{array}{c}0.3316^{* * *} \\
(0.0140)\end{array}$ & $\begin{array}{c}0.3260^{* * * *} \\
(0.0139)\end{array}$ & $\begin{array}{c}0.3121^{* * *} \\
(0.0139)\end{array}$ & $\begin{array}{c}0.2915^{* * *} \\
(0.0148)\end{array}$ & $\begin{array}{c}0.2790^{* * *} \\
(0.0162)\end{array}$ \\
\hline Age 50-59 & $\begin{array}{c}0.2041^{* * *} \\
(0.0083)\end{array}$ & $\begin{array}{c}0.2003^{* * *} \\
(0.0082)\end{array}$ & $\begin{array}{c}0.1934^{* * *} \\
(0.0085)\end{array}$ & $\begin{array}{c}0.1805^{* * *} \\
(0.0093)\end{array}$ & $\begin{array}{c}0.1739^{* * *} \\
(0.0103)\end{array}$ \\
\hline Asian & $\begin{array}{c}0.2508^{* * *} \\
(0.0199)\end{array}$ & $\begin{array}{c}0.2490^{* * *} \\
(0.0215)\end{array}$ & $\begin{array}{c}0.2521^{* * *} \\
(0.0253)\end{array}$ & $\begin{array}{c}0.2616^{* * *} \\
(0.0307)\end{array}$ & $\begin{array}{c}0.2595^{* * *} \\
(0.0336)\end{array}$ \\
\hline Black & $\begin{array}{c}-0.1590^{* * *} \\
(0.0216)\end{array}$ & $\begin{array}{c}-0.1552^{* * *} \\
(0.0207)\end{array}$ & $\begin{array}{c}-0.1467^{* * *} \\
(0.0192)\end{array}$ & $\begin{array}{c}-0.1300^{* * *} \\
(0.0174)\end{array}$ & $\begin{array}{c}-0.1207^{* * *} \\
(0.0175)\end{array}$ \\
\hline Hispanic & $\begin{array}{c}-0.2151^{* * *} \\
(0.0264)\end{array}$ & $\begin{array}{c}-0.2161^{* * *} \\
(0.0250)\end{array}$ & $\begin{array}{c}-0.2170^{* * *} \\
(0.0224)\end{array}$ & $\begin{array}{c}-0.2135^{* * *} \\
(0.0185)\end{array}$ & $\begin{array}{c}-0.2007^{* * * *} \\
(0.0149)\end{array}$ \\
\hline Mismatch as \%mean & 3.33 & 3.29 & 3.13 & 3.1 & 3.01 \\
\hline$R^{2}$ & 0.105 & 0.097 & 0.083 & 0.072 & 0.073 \\
\hline Outcome mean & .495 & .485 & .464 & .443 & .433 \\
\hline $\mathrm{N}$ obs & $327,127,995$ & $300,585,237$ & $247,047,846$ & $194,067,313$ & $164,502,939$ \\
\hline $\mathrm{N}$ cluster (county) & 2,120 & 2,119 & 2,117 & 2,113 & 2,109 \\
\hline County $\times$ Year FE & $\mathrm{Y}$ & $\mathrm{Y}$ & $\mathrm{Y}$ & $\mathrm{Y}$ & $\mathrm{Y}$ \\
\hline
\end{tabular}

Note: This table presents robustness check for Table 3 panel A column (1) by restricting the sample to voters whose name probability is below alternative cutoffs. Column (1) is the same as Table 3 panel A column (1), and columns (2)-(4) uses alternative cutoffs denoted in the table header. All specifications and variable definitions mirror the corresponding columns in Table 3 panel A column (1). 


\section{Table A6}

\section{Political mismatch and the probability of starting a business Re-coding voters with mismatched middle initials}

\begin{tabular}{|c|c|c|c|c|}
\hline & $\begin{array}{c}(1) \\
\text { Regular voter }\end{array}$ & $\begin{array}{c}(2) \\
\text { Active voter }\end{array}$ & $\begin{array}{c}(3) \\
\mathrm{HH} \text { donor }\end{array}$ & $\begin{array}{c}(4) \\
\text { FEC donor }\end{array}$ \\
\hline Mismatch & $\begin{array}{c}-0.0159^{* * * *} \\
(0.0016)\end{array}$ & $\begin{array}{c}-0.0113^{* * *} \\
(0.0019)\end{array}$ & $\begin{array}{c}-0.0132^{* * *} \\
(0.0019)\end{array}$ & $\begin{array}{c}-0.0144^{* * *} \\
(0.0015)\end{array}$ \\
\hline Mismatch $\times$ Active & & $\begin{array}{c}-0.0096^{* * *} \\
(0.0019)\end{array}$ & $\begin{array}{c}-0.0067^{* * *} \\
(0.0020)\end{array}$ & $\begin{array}{c}-0.0335^{* * *} \\
(0.0127)\end{array}$ \\
\hline Dem & $\begin{array}{c}-0.1614^{* * *} \\
(0.0068)\end{array}$ & $\begin{array}{c}-0.1628^{* * *} \\
(0.0083)\end{array}$ & $\begin{array}{c}-0.1612^{* * *} \\
(0.0074)\end{array}$ & $\begin{array}{c}-0.1482^{* * *} \\
(0.0064)\end{array}$ \\
\hline Dem $\times$ Active & & $\begin{array}{l}-0.0043 \\
(0.0070)\end{array}$ & $\begin{array}{c}0.0079 \\
(0.0050)\end{array}$ & $\begin{array}{c}-0.6956^{* * *} \\
(0.0366)\end{array}$ \\
\hline Active & & $\begin{array}{c}0.1090^{* * * *} \\
(0.0081)\end{array}$ & $\begin{array}{c}0.0512^{* * *} \\
(0.0044)\end{array}$ & $\begin{array}{c}1.6213^{* * *} \\
(0.0643)\end{array}$ \\
\hline Male & $\begin{array}{c}0.4264^{* * * *} \\
(0.0203)\end{array}$ & $\begin{array}{c}0.4277^{* * * *} \\
(0.0204)\end{array}$ & $\begin{array}{c}0.4255^{* * *} \\
(0.0203)\end{array}$ & $\begin{array}{c}0.4123^{* * * *} \\
(0.0198)\end{array}$ \\
\hline Age 18-29 & $\begin{array}{c}-0.0403^{* * *} \\
(0.0061)\end{array}$ & $\begin{array}{c}0.0046 \\
(0.0068)\end{array}$ & $\begin{array}{c}-0.0286^{* * *} \\
(0.0061)\end{array}$ & $\begin{array}{l}-0.0030 \\
(0.0053)\end{array}$ \\
\hline Age $30-39$ & $\begin{array}{c}0.3424^{* * * *} \\
(0.0159)\end{array}$ & $\begin{array}{c}0.3761^{* * * *} \\
(0.0158)\end{array}$ & $\begin{array}{c}0.3518^{* * *} \\
(0.0163)\end{array}$ & $\begin{array}{c}0.3713^{* * * *} \\
(0.0170)\end{array}$ \\
\hline Age 40-49 & $\begin{array}{c}0.3316^{* * *} \\
(0.0141)\end{array}$ & $\begin{array}{c}0.3547^{* * * *} \\
(0.0140)\end{array}$ & $\begin{array}{c}0.3350^{* * *} \\
(0.0143)\end{array}$ & $\begin{array}{c}0.3517^{* * * *} \\
(0.0150)\end{array}$ \\
\hline Age 50-59 & $\begin{array}{c}0.2029^{* * *} \\
(0.0083)\end{array}$ & $\begin{array}{c}0.2142^{* * *} \\
(0.0082)\end{array}$ & $\begin{array}{c}0.2035^{* * *} \\
(0.0083)\end{array}$ & $\begin{array}{c}0.2128^{* * *} \\
(0.0087)\end{array}$ \\
\hline Asian & $\begin{array}{c}0.2426^{* * * *} \\
(0.0219)\end{array}$ & $\begin{array}{c}0.2533^{* * *} * \\
(0.0226)\end{array}$ & $\begin{array}{c}0.2429 * * * \\
(0.0218)\end{array}$ & $\begin{array}{c}0.2473^{* * *} \\
(0.0215)\end{array}$ \\
\hline Black & $\begin{array}{c}-0.1519^{* * *} \\
(0.0211)\end{array}$ & $\begin{array}{c}-0.1493^{* * *} \\
(0.0211)\end{array}$ & $\begin{array}{c}-0.1451^{* * *} \\
(0.0208)\end{array}$ & $\begin{array}{c}-0.1362^{* * *} \\
(0.0205)\end{array}$ \\
\hline Hispanic & $\begin{array}{c}-0.2093^{* * *} \\
(0.0259)\end{array}$ & $\begin{array}{c}-0.1960^{* * *} \\
(0.0264)\end{array}$ & $\begin{array}{c}-0.2004^{* * *} \\
(0.0258)\end{array}$ & $\begin{array}{c}-0.1921^{* * * *} \\
(0.0250)\end{array}$ \\
\hline Mismatch as \%mean & 3.34 & 2.38 & 2.78 & 3.04 \\
\hline Mismatch $\times$ Active as $\%$ mean & - & 2.01 & 1.39 & 7.03 \\
\hline$R^{2}$ & 0.102 & 0.069 & 0.070 & 0.080 \\
\hline Outcome mean & .476 & .477 & .476 & .476 \\
\hline $\mathrm{N}$ obs & $327,127,995$ & $326,699,233$ & $327,127,995$ & $327,127,995$ \\
\hline $\mathrm{N}$ cluster (county) & 2,120 & 2,120 & 2,120 & 2,120 \\
\hline County $\times$ Year FE & $\mathrm{Y}$ & Y & $\mathrm{Y}$ & $\mathrm{Y}$ \\
\hline
\end{tabular}

Note: This table serves as a robustness check for Table 3 panel A by re-coding those voters that are matched to founders, but whose middle initials do not match (and non-missing), as non-founders. These correspond to approximately $4.5 \%$ of observations. All specifications and variable definitions mirror the corresponding columns in Table 3 panel A. 
Table A7

Political mismatch and the probability of starting a business Large counties only

\begin{tabular}{|c|c|c|c|c|}
\hline & $\begin{array}{c}(1) \\
\text { Regular voter }\end{array}$ & $\begin{array}{c}(2) \\
\text { Active voter }\end{array}$ & $\begin{array}{c}(3) \\
\mathrm{HH} \text { donor }\end{array}$ & $\begin{array}{c}(4) \\
\text { FEC donor }\end{array}$ \\
\hline Mismatch & $\begin{array}{c}-0.0215^{* * *} \\
(0.0039)\end{array}$ & $\begin{array}{c}-0.0163^{* * *} \\
(0.0045)\end{array}$ & $\begin{array}{c}-0.0224^{* * *} \\
(0.0045)\end{array}$ & $\begin{array}{c}-0.0190^{* * *} \\
(0.0037)\end{array}$ \\
\hline Mismatch $\times$ Active & & $\begin{array}{c}-0.0136^{* * *} \\
(0.0038)\end{array}$ & $\begin{array}{c}0.0017 \\
(0.0039)\end{array}$ & $\begin{array}{c}-0.0586^{* *} \\
(0.0224)\end{array}$ \\
\hline Dem & $\begin{array}{c}-0.1993^{* * *} \\
(0.0178)\end{array}$ & $\begin{array}{c}-0.2259^{* * *} \\
(0.0213)\end{array}$ & $\begin{array}{c}-0.2110^{* * *} \\
(0.0194)\end{array}$ & $\begin{array}{c}-0.1835^{* * *} \\
(0.0168)\end{array}$ \\
\hline Dem $\times$ Active & & $\begin{array}{c}0.0504^{* * *} \\
(0.0175)\end{array}$ & $\begin{array}{c}0.0373^{* * *} \\
(0.0113)\end{array}$ & $\begin{array}{c}-0.8450^{* * *} \\
(0.0897)\end{array}$ \\
\hline Active & & $\begin{array}{l}0.0361^{*} \\
(0.0192)\end{array}$ & $\begin{array}{c}0.0412^{* * *} \\
(0.0118)\end{array}$ & $\begin{array}{c}1.8771^{* * *} \\
(0.1583)\end{array}$ \\
\hline Male & $\begin{array}{c}0.5952^{* * * *} \\
(0.0518)\end{array}$ & $\begin{array}{c}0.5969^{* * *} \\
(0.0519)\end{array}$ & $\begin{array}{c}0.5943^{* * *} \\
(0.0517)\end{array}$ & $\begin{array}{c}0.5774^{* * * *} \\
(0.0506)\end{array}$ \\
\hline Age 18-29 & $\begin{array}{c}-0.0647^{* * *} \\
(0.0147)\end{array}$ & $\begin{array}{c}-0.0365^{* *} \\
(0.0154)\end{array}$ & $\begin{array}{c}-0.0489^{* * *} \\
(0.0154)\end{array}$ & $\begin{array}{l}-0.0164 \\
(0.0142)\end{array}$ \\
\hline Age $30-39$ & $\begin{array}{c}0.4228^{* * * *} \\
(0.0408)\end{array}$ & $\begin{array}{c}0.4426^{* * *} \\
(0.0413)\end{array}$ & $\begin{array}{c}0.4362^{* * *} \\
(0.0423)\end{array}$ & $\begin{array}{c}0.4592^{* * * *} \\
(0.0434)\end{array}$ \\
\hline Age 40-49 & $\begin{array}{c}0.4313^{* * *} \\
(0.0360)\end{array}$ & $\begin{array}{c}0.4442^{* * *} \\
(0.0363)\end{array}$ & $\begin{array}{c}0.4371^{* * *} \\
(0.0367)\end{array}$ & $\begin{array}{c}0.4558^{* * *} \\
(0.0379)\end{array}$ \\
\hline Age 50-59 & $\begin{array}{c}0.2623^{* * * *} \\
(0.0219)\end{array}$ & $\begin{array}{c}0.2686^{* * * *} \\
(0.0221)\end{array}$ & $\begin{array}{c}0.2638^{* * *} \\
(0.0221)\end{array}$ & $\begin{array}{c}0.2746^{* * *} \\
(0.0229)\end{array}$ \\
\hline Asian & $\begin{array}{c}0.2844^{* * *} \\
(0.0287)\end{array}$ & $\begin{array}{c}0.2917^{* * * *} \\
(0.0299)\end{array}$ & $\begin{array}{c}0.2844^{* * *} \\
(0.0286)\end{array}$ & $\begin{array}{c}0.2943^{* * *} \\
(0.0282)\end{array}$ \\
\hline Black & $\begin{array}{c}-0.1280^{* * *} \\
(0.0442)\end{array}$ & $\begin{array}{c}-0.1241^{* * *} \\
(0.0440)\end{array}$ & $\begin{array}{c}-0.1188^{* * *} \\
(0.0434)\end{array}$ & $\begin{array}{c}-0.1031^{* *} \\
(0.0430)\end{array}$ \\
\hline Hispanic & $\begin{array}{c}-0.2317^{* * *} \\
(0.0429)\end{array}$ & $\begin{array}{c}-0.2218^{* * *} \\
(0.0438)\end{array}$ & $\begin{array}{c}-0.2208^{* * *} \\
(0.0428)\end{array}$ & $\begin{array}{c}-0.2073^{* * *} \\
(0.0414)\end{array}$ \\
\hline Mismatch as \%mean & 3.42 & 2.59 & 3.56 & 3.03 \\
\hline Mismatch $\times$ Active as $\%$ mean & - & 2.15 & .27 & 9.32 \\
\hline$R^{2}$ & 0.256 & 0.175 & 0.176 & 0.181 \\
\hline Outcome mean & .628 & .628 & .628 & .628 \\
\hline $\mathrm{N}$ obs & $115,683,441$ & $115,543,058$ & $115,683,441$ & $115,683,441$ \\
\hline $\mathrm{N}$ cluster (county) & 98 & 98 & 98 & 98 \\
\hline County $\times$ Year FE & $\mathrm{Y}$ & $\mathrm{Y}$ & $\mathrm{Y}$ & Y \\
\hline
\end{tabular}

Note: This table presents robustness check for Table 3 panel A by restricting the sample to counties with at least 300,000 voters in the voter file data (approximately the 95th percentile of US counties). All specifications and variable definitions mirror the corresponding columns in Table 3 panel A. 


\section{Table A8}

\section{Political mismatch and new firms Democratic vs. Republican counties}

\begin{tabular}{|c|c|c|}
\hline & $\begin{array}{c}(1) \\
\text { Election } 2008 \\
\end{array}$ & $\begin{array}{c}(2) \\
\text { Election } 2016 \\
\end{array}$ \\
\hline Dem $\times-7 Q$ & $\begin{array}{l}-0.463 \\
(0.789)\end{array}$ & $\begin{array}{c}0.592 \\
(1.474)\end{array}$ \\
\hline Dem $\times-6 Q$ & $\begin{array}{c}0.058 \\
(0.727)\end{array}$ & $\begin{array}{l}-0.393 \\
(1.536)\end{array}$ \\
\hline Dem $\times-5 Q$ & $\begin{array}{c}0.136 \\
(0.663)\end{array}$ & $\begin{array}{c}0.005 \\
(1.387)\end{array}$ \\
\hline Dem $\times-4 Q$ & $\begin{array}{c}0.228 \\
(0.505)\end{array}$ & $\begin{array}{l}-0.211 \\
(1.356)\end{array}$ \\
\hline Dem×-3Q & $\begin{array}{c}0.213 \\
(0.394)\end{array}$ & $\begin{array}{l}-0.522 \\
(1.346)\end{array}$ \\
\hline $\operatorname{Dem} \times-1 \mathrm{Q}$ & $\begin{array}{l}-0.414 \\
(0.466)\end{array}$ & $\begin{array}{l}-1.624^{*} \\
(0.858)\end{array}$ \\
\hline Dem $\times 0 \mathrm{Q}$ & $\begin{array}{l}-0.084 \\
(0.635)\end{array}$ & $\begin{array}{c}-1.989 * * \\
(1.009)\end{array}$ \\
\hline Dem $\times 1 Q$ & $\begin{array}{c}0.731 \\
(0.536)\end{array}$ & $\begin{array}{c}-4.068^{* * *} \\
(1.219)\end{array}$ \\
\hline $\operatorname{Dem} \times 2 \mathrm{Q}$ & $\begin{array}{l}1.294^{* *} \\
(0.552)\end{array}$ & $\begin{array}{l}-2.499 \\
(1.650)\end{array}$ \\
\hline Dem $\times 3 Q$ & $\begin{array}{c}2.413^{* * *} \\
(0.612)\end{array}$ & $\begin{array}{c}-4.080^{* *} \\
(1.928)\end{array}$ \\
\hline Dem $\times 4 \mathrm{Q}$ & $\begin{array}{l}1.730^{* *} \\
(0.686)\end{array}$ & $\begin{array}{l}-2.411 \\
(2.028)\end{array}$ \\
\hline Dem $\times 5 \mathrm{Q}$ & $\begin{array}{c}1.984^{* * *} * \\
(0.767)\end{array}$ & \\
\hline Dem $\times 6 Q$ & $\begin{array}{c}0.910 \\
(0.842)\end{array}$ & \\
\hline Dem $\times 7 \mathrm{Q}$ & $\begin{array}{l}1.500 \\
(1.018)\end{array}$ & \\
\hline Avg $1-4 Q$ as $\%$ mean & 2.29 & -3.97 \\
\hline$R^{2}$ & 0.109 & 0.015 \\
\hline Outcome mean & 67.109 & 82.253 \\
\hline $\mathrm{N}$ obs & 129,240 & 100,520 \\
\hline $\mathrm{N}$ cluster (county) & 2872 & 2872 \\
\hline County FE & $\mathrm{Y}$ & $\mathrm{Y}$ \\
\hline Quarter FE & $\mathrm{Y}$ & $\mathrm{Y}$ \\
\hline Economic controls & $\mathrm{Y}$ & $\mathrm{Y}$ \\
\hline
\end{tabular}

Note: This table presents the estimated coefficients from equation 3 (also see Figure 5). Republican-leaning counties are the omitted group. Event time 0 refers to the three months following the month of a presidential election. For example, for the 2016 election event time 0 is November 2016 to January 2017. Event time -2 is the omitted period. All regressions control for county fixed effects, event time fixed effects, and county economic conditions (monthly unemployment rate, annual per capita income, and annual employment share for NAICS-2 industries). Regressions are weighted by county population ages 20 and above. Standard errors are clustered by county. 
Table A9

Political mismatch and new firms

More and less optimistic Democratic vs. Republican counties

\begin{tabular}{|c|c|c|}
\hline & $\begin{array}{c}(1) \\
\text { Econ condition }\end{array}$ & $\begin{array}{c}(2) \\
\text { Living standard }\end{array}$ \\
\hline Optimistic Dem $\times-7$ & $\begin{array}{l}-1.019 \\
(1.414)\end{array}$ & $\begin{array}{l}-1.647 \\
(1.498)\end{array}$ \\
\hline Optimistic Dem $\times-6$ & $\begin{array}{l}-0.744 \\
(1.296)\end{array}$ & $\begin{array}{l}-1.624 \\
(1.304)\end{array}$ \\
\hline Optimistic Dem $\times-5$ & $\begin{array}{l}-0.987 \\
(1.242)\end{array}$ & $\begin{array}{l}-1.787 \\
(1.258)\end{array}$ \\
\hline Optimistic Dem $\times-4$ & $\begin{array}{c}0.813 \\
(0.791)\end{array}$ & $\begin{array}{c}0.442 \\
(0.828)\end{array}$ \\
\hline Optimistic Dem $\times-3$ & $\begin{array}{c}0.242 \\
(0.600)\end{array}$ & $\begin{array}{l}-0.032 \\
(0.534)\end{array}$ \\
\hline Optimistic Dem $\times-1$ & $\begin{array}{c}0.384 \\
(0.711)\end{array}$ & $\begin{array}{c}0.131 \\
(0.782)\end{array}$ \\
\hline Optimistic Dem $\times 0$ & $\begin{array}{l}-0.507 \\
(0.978)\end{array}$ & $\begin{array}{l}-0.790 \\
(1.003)\end{array}$ \\
\hline Optimistic Dem $\times 1$ & $\begin{array}{l}-0.204 \\
(0.838)\end{array}$ & $\begin{array}{l}-0.691 \\
(0.856)\end{array}$ \\
\hline Optimistic Dem $\times 2$ & $\begin{array}{c}0.738 \\
(0.856)\end{array}$ & $\begin{array}{c}0.561 \\
(0.902)\end{array}$ \\
\hline Optimistic Dem $\times 3$ & $\begin{array}{c}3.184^{* * * *} \\
(1.021)\end{array}$ & $\begin{array}{c}3.140^{* * * *} \\
(1.088)\end{array}$ \\
\hline Optimistic Dem $\times 4$ & $\begin{array}{c}3.228^{* * * *} \\
(1.113)\end{array}$ & $\begin{array}{l}2.804 * * \\
(1.091)\end{array}$ \\
\hline Optimistic Dem $\times 5$ & $\begin{array}{l}2.846^{* *} \\
(1.227)\end{array}$ & $\begin{array}{l}3.002 * * \\
(1.254)\end{array}$ \\
\hline Optimistic Dem $\times 6$ & $\begin{array}{l}2.225^{*} \\
(1.306)\end{array}$ & $\begin{array}{l}2.618^{*} \\
(1.366)\end{array}$ \\
\hline Optimistic Dem $\times 7$ & $\begin{array}{l}3.671^{* *} \\
(1.806)\end{array}$ & $\begin{array}{c}4.033^{* *} \\
(1.992)\end{array}$ \\
\hline Pessimistic Dem $\times-7$ & $\begin{array}{l}-0.368 \\
(1.222)\end{array}$ & $\begin{array}{c}0.079 \\
(1.218)\end{array}$ \\
\hline Pessimistic Dem $\times-6$ & $\begin{array}{c}0.101 \\
(1.130)\end{array}$ & $\begin{array}{c}0.715 \\
(1.167)\end{array}$ \\
\hline Pessimistic Dem $\times-5$ & $\begin{array}{l}-0.308 \\
(0.925)\end{array}$ & $\begin{array}{c}0.256 \\
(1.006)\end{array}$ \\
\hline Pessimistic Dem $\times-4$ & $\begin{array}{c}0.159 \\
(0.782)\end{array}$ & $\begin{array}{c}0.591 \\
(0.773)\end{array}$ \\
\hline Pessimistic Dem $\times-3$ & $\begin{array}{c}0.622 \\
(0.578)\end{array}$ & $\begin{array}{c}0.801 \\
(0.614)\end{array}$ \\
\hline Pessimistic Dem $\times-1$ & $\begin{array}{l}-1.064 \\
(0.745)\end{array}$ & $\begin{array}{l}-0.629 \\
(0.693)\end{array}$ \\
\hline Pessimistic Dem $\times 0$ & $\begin{array}{l}-0.507 \\
(1.066)\end{array}$ & $\begin{array}{l}-0.262 \\
(1.021)\end{array}$ \\
\hline Pessimistic Dem $\times 1$ & $\begin{array}{c}0.111 \\
(0.873)\end{array}$ & $\begin{array}{c}0.462 \\
(0.841)\end{array}$ \\
\hline Pessimistic Dem $\times 2$ & $\begin{array}{l}1.165 \\
(0.988)\end{array}$ & $\begin{array}{l}1.224 \\
(0.927)\end{array}$ \\
\hline Pessimistic Dem $\times 3$ & $\begin{array}{c}0.856 \\
(1.005)\end{array}$ & $\begin{array}{l}1.224 \\
(0.981)\end{array}$ \\
\hline Pessimistic Dem $\times 4$ & $\begin{array}{c}0.582 \\
(1.071)\end{array}$ & $\begin{array}{c}1.343 \\
(1.159)\end{array}$ \\
\hline Pessimistic Dem $\times 5$ & $\begin{array}{c}0.846 \\
(1.185)\end{array}$ & $\begin{array}{c}1.054 \\
(1.229)\end{array}$ \\
\hline Pessimistic Dem $\times 6$ & $\begin{array}{l}-0.315 \\
(1.237)\end{array}$ & $\begin{array}{l}-0.225 \\
(1.267)\end{array}$ \\
\hline Pessimistic Dem $\times 7$ & $\begin{array}{c}0.011 \\
(1.335)\end{array}$ & $\begin{array}{c}0.300 \\
(1.376)\end{array}$ \\
\hline$R^{2}$ & 0.182 & 0.184 \\
\hline Outcome mean & 74.685 & 74.685 \\
\hline $\mathrm{N}$ obs & 32,175 & 32,175 \\
\hline $\mathrm{N}$ cluster (county) & 715 & 715 \\
\hline County FE & $\mathrm{Y}$ & $\mathrm{Y}$ \\
\hline Quarter FE & $\mathrm{Y}$ & $\mathrm{Y}$ \\
\hline Economic controls & $\mathrm{Y}$ & $\mathrm{Y}$ \\
\hline
\end{tabular}

Note: This table presents coefficient estimates from a county-level specification similar to equation 3 (and Figure 7 ). More (less) optimistic counties are those that have an above-median (below-median) change in optimism between 2008 and 2009. Column (1) measures optimism using respondents' average response ("Poor", "Only fair", "Good", and "Excellent") to the question "How would you rate economic conditions in this country today?" and column (2) the percentage of respondents choosing "Getting better" to the question "Right now, do you feel your standard of living is getting better or getting worse?" in the Gallup U.S. Daily Survey. Republican-leaning counties are the omitted group. Event time 0 refers to November 2008 to January 2009. Event time -2 is the omitted period. All regressions control for county fixed effects, event time fixed effects, and county economic conditions (monthly unemployment rate, annual per capita income, and annual employment share for NAICS-2 industries). Regressions are weighted by county population ages 20 and above. Standard errors are clustered by county. 
Table A10

\section{Political mismatch and the probability of starting a business By counties' correlation with the national economy}

\begin{tabular}{|c|c|c|c|c|}
\hline & (1) & $(2)$ & $(3)$ & $(4)$ \\
\hline & \multicolumn{4}{|c|}{ Quartile of county correlation with US GDP growth } \\
\hline & First & Second & Third & Fourth \\
\hline Mismatch & $\begin{array}{c}-0.0060^{* *} \\
(0.0030)\end{array}$ & $\begin{array}{c}-0.0124^{* * *} \\
(0.0033)\end{array}$ & $\begin{array}{c}-0.0145^{* * * *} \\
(0.0036)\end{array}$ & $\begin{array}{c}-0.0206^{* * * *} \\
(0.0025)\end{array}$ \\
\hline Dem & $\begin{array}{c}-0.1405^{* * *} \\
(0.0130)\end{array}$ & $\begin{array}{c}-0.1651^{* * *} \\
(0.0149)\end{array}$ & $\begin{array}{c}-0.1327^{* * *} * \\
(0.0113)\end{array}$ & $\begin{array}{c}-0.1841^{* * *} \\
(0.0109)\end{array}$ \\
\hline Male & $\begin{array}{c}0.3034^{* * *} \\
(0.0182)\end{array}$ & $\begin{array}{c}0.3559 * * * \\
(0.0228)\end{array}$ & $\begin{array}{c}0.3632^{* * *} \\
(0.0330)\end{array}$ & $\begin{array}{c}0.5280^{* * *} \\
(0.0346)\end{array}$ \\
\hline Age 18-29 & $\begin{array}{c}-0.0188^{* * *} \\
(0.0066)\end{array}$ & $\begin{array}{c}-0.0485^{* * *} \\
(0.0086)\end{array}$ & $\begin{array}{c}-0.0376^{* * *} \\
(0.0127)\end{array}$ & $\begin{array}{c}-0.0545^{* * *} \\
(0.0105)\end{array}$ \\
\hline Age $30-39$ & $\begin{array}{c}0.2618^{* * *} \\
(0.0176)\end{array}$ & $\begin{array}{c}0.2956^{* * *} \\
(0.0232)\end{array}$ & $\begin{array}{c}0.2853^{* * *} \\
(0.0252)\end{array}$ & $\begin{array}{c}0.4019 \text { *** } \\
(0.0267)\end{array}$ \\
\hline Age $40-49$ & $\begin{array}{c}0.2347^{* * *} \\
(0.0144)\end{array}$ & $\begin{array}{c}0.2776^{* * *} \\
(0.0191)\end{array}$ & $\begin{array}{c}0.2854^{* * *} \\
(0.0252)\end{array}$ & $\begin{array}{c}0.3951^{* * *} \\
(0.0229)\end{array}$ \\
\hline Age $50-59$ & $\begin{array}{c}0.1518^{* * *} \\
(0.0089)\end{array}$ & $\begin{array}{c}0.1696^{* * *} \\
(0.0100)\end{array}$ & $\begin{array}{c}0.1781^{* * *} \\
(0.0162)\end{array}$ & $\begin{array}{c}0.2420^{* * *} \\
(0.0134)\end{array}$ \\
\hline Asian & $\begin{array}{c}0.1559 * * * \\
(0.0224)\end{array}$ & $\begin{array}{c}0.1666^{* * *} \\
(0.0332)\end{array}$ & $\begin{array}{c}0.2730 * * * \\
(0.0533)\end{array}$ & $\begin{array}{c}0.2727^{* * *} \\
(0.0264)\end{array}$ \\
\hline Black & $\begin{array}{c}-0.2270 * * * \\
(0.0386)\end{array}$ & $\begin{array}{c}-0.1752^{* * *} \\
(0.0400)\end{array}$ & $\begin{array}{c}-0.1006^{* * *} \\
(0.0229)\end{array}$ & $\begin{array}{c}-0.1739^{* * *} \\
(0.0378)\end{array}$ \\
\hline Hispanic & $\begin{array}{c}-0.2059^{* * *} \\
(0.0210)\end{array}$ & $\begin{array}{c}-0.1962^{* * *} \\
(0.0193)\end{array}$ & $\begin{array}{c}-0.2169^{* * *} \\
(0.0192)\end{array}$ & $\begin{array}{c}-0.2228^{* * *} \\
(0.0433)\end{array}$ \\
\hline Mismatch as \%mean & 1.56 & 2.76 & 3.34 & 3.65 \\
\hline$R^{2}$ & 0.039 & 0.065 & 0.097 & 0.159 \\
\hline Outcome mean & .383 & .449 & .435 & .565 \\
\hline $\mathrm{N}$ obs & 35914427 & 51788941 & 80490173 & 158934454 \\
\hline $\mathrm{N}$ cluster (county) & 566 & 517 & 519 & 518 \\
\hline County $\times$ Year FE & Y & Y & $\mathrm{Y}$ & Y \\
\hline
\end{tabular}

Note: This table presents the heterogeneity in the mismatch effect in Table 3 panel A column (1) by restricting the sample to counties in each of the four quartiles of correlation with the US GDP growth between 2001 and 2017 (quartile cutoffs are 0.21, 0.70, and 0.88). All specifications and variable definitions mirror Table 3 panel A column (1). 
Table A11

Political mismatch and the probability of starting a business Democrat and Republican vs. Independent Individuals

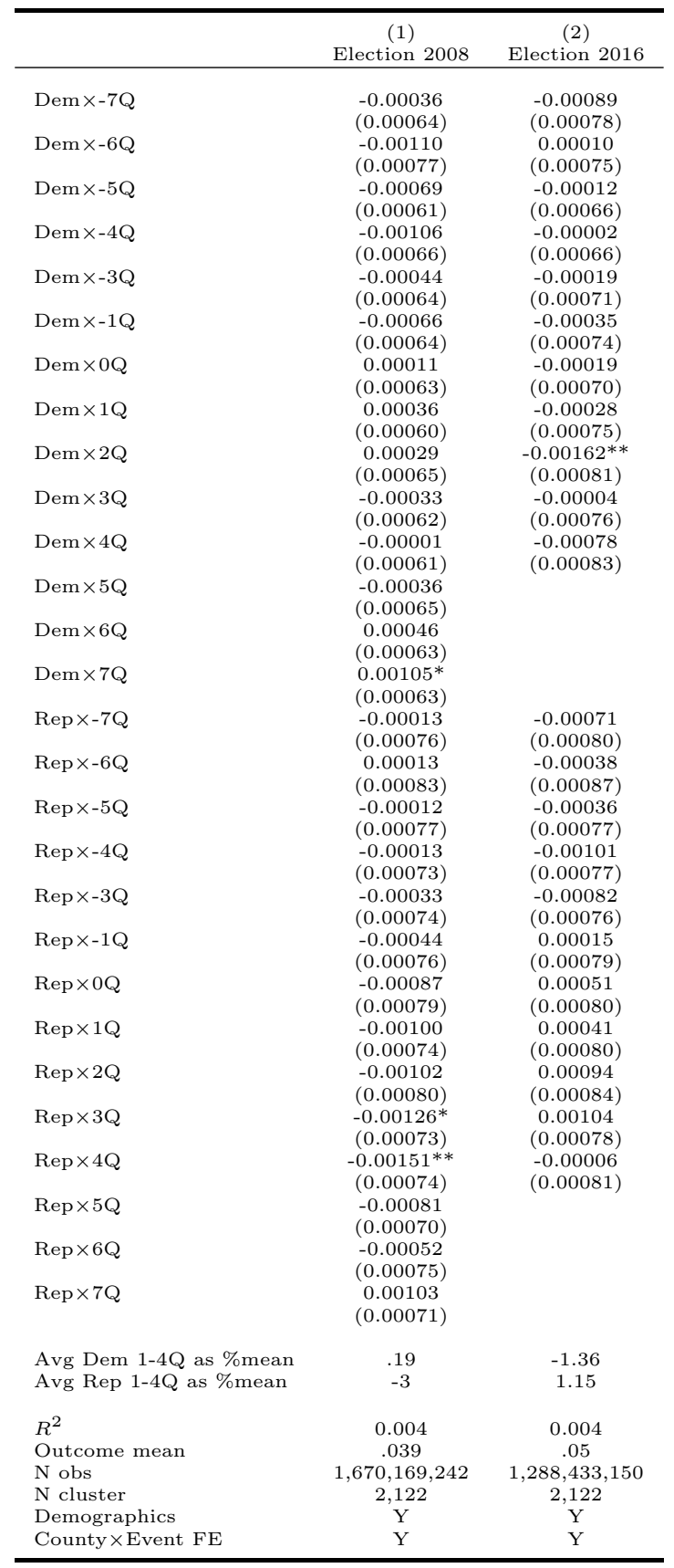

Note: The table provides estimated coefficients from a modified version of equation 1 (also see Fig 3), capturing Democrats' and Republicans' excess probability of starting a business relative to independent voters (omitted group). Units are in percentage points. Dem (Rep) is one for Democrats (Republicans) and zero otherwise (see section 2.2 for definitions of partisanship). Event time 0 refers to the three months following the month of a presidential election. For example, for the 2016 election, event time is 0 for November 2016 to January 2017. Event time -2 is the omitted period. All regressions control for county $\times$ event fixed effects and voter demographics (i.e., gender, age groups, race). Regressions are run at the county-party-characteristic-month cell and are weighted by the number of observations in each cell. Standard errors are clustered by county. 
Table A12

Political mismatch and employer firms

County-level business dynamics (excluding economic controls)

\begin{tabular}{|c|c|c|c|c|c|c|c|}
\hline & \multirow{2}{*}{\multicolumn{2}{|c|}{ New firm }} & \multirow[t]{2}{*}{$(3)$} & $(4)$ & \multirow{2}{*}{\multicolumn{2}{|c|}{$\begin{array}{c}(5) \\
\text { xisting firm }\end{array}$}} & \multirow{3}{*}{$\begin{array}{c}(7) \\
\text { All firm } \\
\text { Net job creation rate }\end{array}$} \\
\hline & & & & & & & \\
\hline & Firm entry & Job creation rate & Estab. entry & Estab. exit & Firm death & Net job creation rate & \\
\hline Mismatch & $\begin{array}{c}-4.964^{* * *} \\
(1.017)\end{array}$ & $\begin{array}{l}-0.003 \\
(0.002)\end{array}$ & $\begin{array}{c}-0.287^{* * *} \\
(0.091)\end{array}$ & $\begin{array}{c}0.484^{* * * *} \\
(0.175)\end{array}$ & $\begin{array}{c}0.518^{* * * *} \\
(0.122)\end{array}$ & $\begin{array}{c}-0.188^{* * *} \\
(0.058)\end{array}$ & $\begin{array}{c}-0.186^{* * *} \\
(0.057)\end{array}$ \\
\hline Mismatch as \%mean & 2.6 & 0.01 & 1.02 & 0.68 & 1.09 & 17.55 & 19.46 \\
\hline$R^{2}$ & 0.902 & 0.075 & 0.671 & 0.775 & 0.816 & 0.235 & 0.953 \\
\hline Outcome mean & 191.523 & 199.997 & 28.123 & 70.618 & 47.256 & -1.069 & 0.954 \\
\hline $\mathrm{N}$ obs & 41,986 & 41,575 & 128,475 & 149,157 & 140,668 & 173,018 & 214,603 \\
\hline $\mathrm{N}$ cluster (county) & 3,111 & 3085 & 3,111 & 3,111 & 3,111 & 3,110 & 3,110 \\
\hline County FE & $\mathrm{Y}$ & $\mathrm{Y}$ & $\mathrm{Y}$ & $\mathrm{Y}$ & $\mathrm{Y}$ & $\mathrm{Y}$ & $\mathrm{Y}$ \\
\hline Year FE & $\mathrm{Y}$ & $\mathrm{Y}$ & $\mathrm{N}$ & $\mathrm{N}$ & $\mathrm{N}$ & $\mathrm{N}$ & $\mathrm{N}$ \\
\hline Firm age $\times$ Year FE & $\mathrm{N}$ & $\mathrm{N}$ & $\mathrm{Y}$ & $\mathrm{Y}$ & $\mathrm{Y}$ & $\mathrm{Y}$ & $\mathrm{Y}$ \\
\hline Economic controls & $\mathrm{N}$ & $\mathrm{N}$ & $\mathrm{N}$ & $\mathrm{N}$ & $\mathrm{N}$ & $\mathrm{N}$ & $\mathrm{N}$ \\
\hline
\end{tabular}

Note: This table presents a robustness test for Table 6 . All specifications mirror those in the corresponding columns of Table 6

except that we exclude controls for county economic conditions in this table. 


\section{Industry TAgging Algorithm}

Our firm registration data does not include industry codes. To assign firms to industries we develop an industry tagging algorithm based on the words in firm names. Our approach proceeds in three steps.

First, we consider all firms with a primary NAICS code assigned in a large firm dataset provided by Infogroup USA. ${ }^{1}$ We count the number of times a word appears in firm names for each NAICS two-digit industry. Second, we define word quotient as the number of times a word appears in an industry divided by the number of firms in an industry - we scale the word frequency to avoid industries with many firms dominating the classification. For example, words like "mining" or "biotechnology" are highly relevant to industries with relatively few firms. Third, we assign each word to an industry if (i) it has the highest word quotient and (ii) the quotient is at least twice as high as the next highest one (quotient ratio $\geq 2$ ). Firms are then linked to industries if the words in their names are assigned to a specific industry.

Words with the highest quotient ratio (i.e., those that are most closely associated with specific industries), include "wharehousing" (NAICS 49), "mining" and "quarry" (NAICS 21), and "winery" and "panaderia" (NAICS 31). The median value of the quotient ratio is 8.5. Words around this value include "attorneys" (NAICS 52), "volkswagen" (NAICS 44), "key" (NAICS 56), "powerwashing" (NAICS 23), "abstract" (NAICS 54), and "cooling" (NAICS 23).

In total, we have 5,507 words which tag about $54.6 \%$ of companies in our regression sample. We exclude N55 and N99. Within these tagged companies, $81 \%$ are assigned to exactly one industry, $17.2 \%$ to two, and $1.8 \%$ to three or more. Many of the companies tagged in two industries are those that span multiple sectors, such as "Commercial Properties Magazine, Inc", which is tagged as NAICS 51 (Information) and 53 (Real Estate), or "Stella

\footnotetext{
${ }^{1}$ Infogroup USA dataset includes firms covering the majority of the U.S. economy (similar to Dunn \& Brandstreet).
} 
Kids Yoga" which is tagged as NAICS 61 (Educational Services) and 62 (Health Care and Social Assistance).

In our main analysis, we assign a firm an industry as long as it is tagged to that industry, i.e., a firm can be tagged to multiple industries. In untabulated results, our findings are robust to assigning a firm an industry when the firm is tagged to only one industry. 